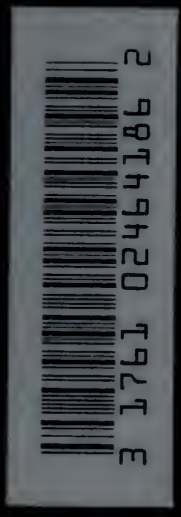




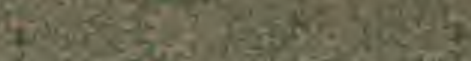

W.

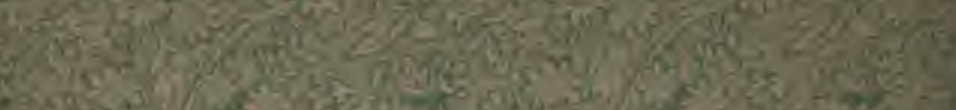

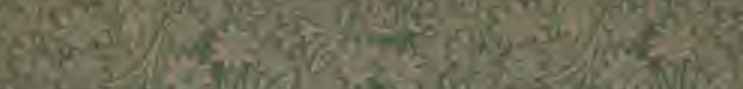

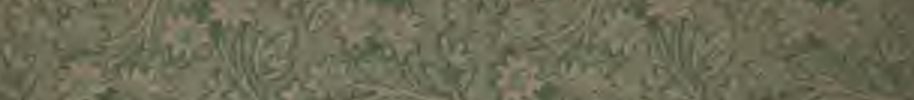

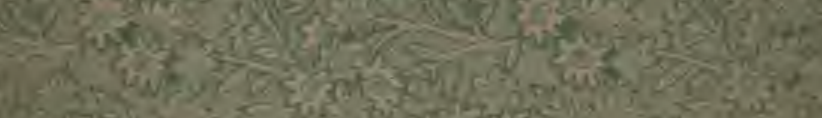

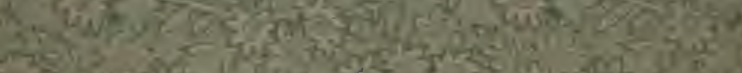

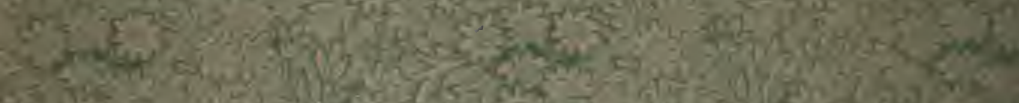

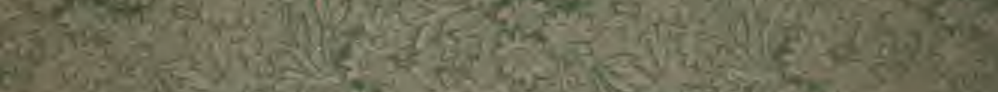

S.

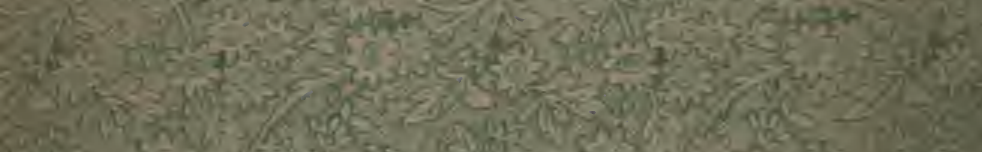

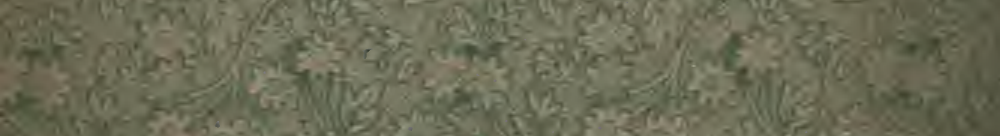

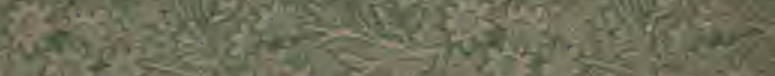

$$
\text { Evis. }
$$

zF

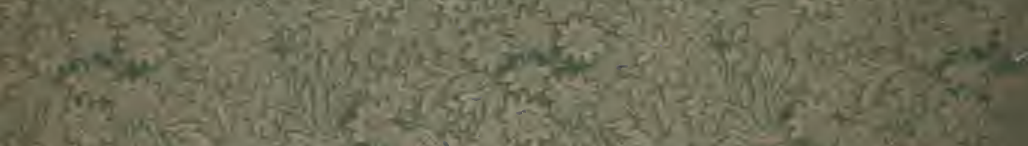
4. Jy

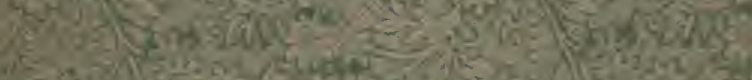

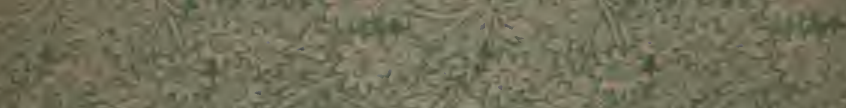

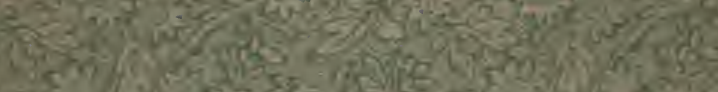

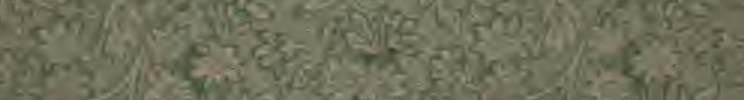

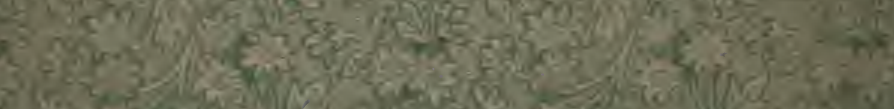

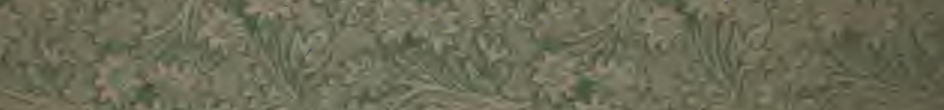
She

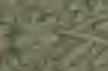$$
40
$$

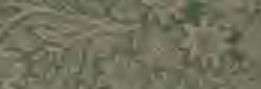
$20 x^{2}+2 x$

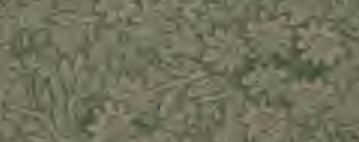

2i

2,37

Q

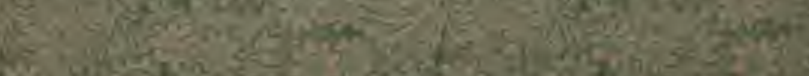





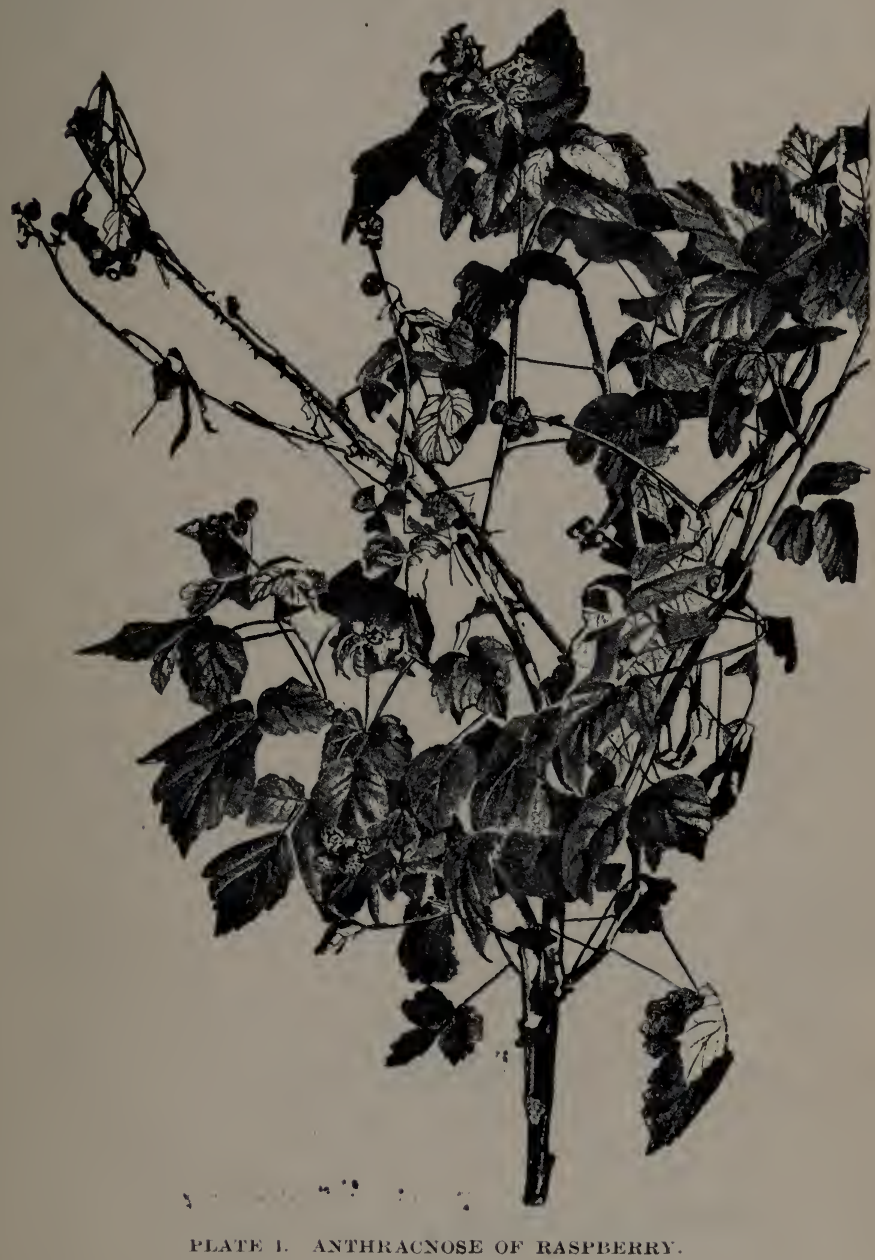





\title{
FUNGI AND FUNGICIDES
}

\section{A PRACTICAL MANUAL}

\author{
CONCERNING THE
}

Fungous Diseases of Cultivated Plants

\author{
AND THE
}

Means of Preventing Their Ravages

BY

ClARENCE, M. WEED, D. SC.

$$
\underbrace{\text { ILLUPPATEDhe IIDrary }}_{\text {Of }}
$$

\section{R. B. Thomson}

NEW YORK

ORANGE JUDD COMPANY 


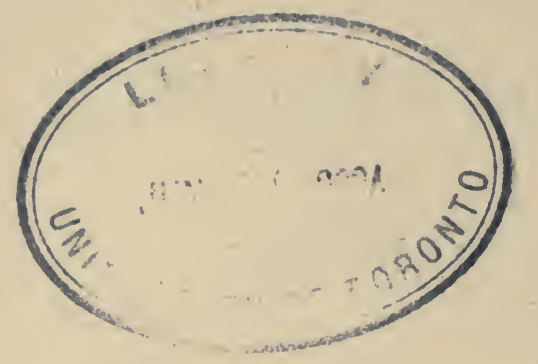

\section{By the SAME Author}

\section{INSECTS AND INSEOTICIDES}

A Practical Manual Concerning Noxious Insects and the Methods of Preventing their Injuries. Profusely Illustrated, 280 pages, handsomely bound in cloth with embossed cover. Price, $\$ 1.25$.

\section{SPFAYING CROPS}

Why, When and How. Illustrated. Second (Revised) Edition. Seventh Thousand. 130 pages. Price, 25 cents.

$\angle I B P A P$

$$
\text { i }
$$

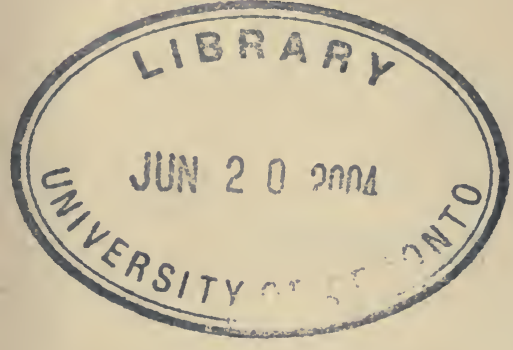




\section{CONTENTS}

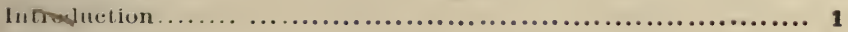

P.ART I. FungI AFFECTING the LARger Frutts

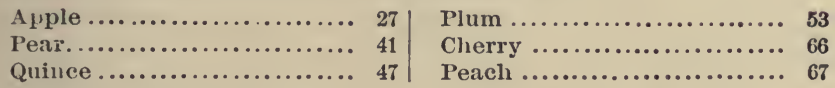

Part il. Fungi Affecting Small Fruits

Grape $\ldots \ldots \ldots \ldots \ldots \ldots \ldots \ldots, 79$ Raspberry and Blackberry .. 97

Currant and Gooseberry .... 91 Strawberry ............... 104

Part ill. Fungi Affecting Shade trees, Ornamental Plants AND FLOWERS

Shade Trees ............... 111

Flowers .................. 119

Rose ..................... 114

Part iV. Fungi Affecting Vegetables

Bean .................... 123

Beet $\ldots \ldots \ldots \ldots \ldots \ldots \ldots \ldots \ldots .135$

Cabbage ................... 138

Celery $\ldots . \ldots \ldots \ldots \ldots \ldots \ldots \ldots . . . \ldots 144$

Onion $\ldots \ldots \ldots \ldots \ldots \ldots \ldots \ldots \ldots$

Cucumber and melon......... 160
Potato ..................... 164

Sweet Potato ............... 172

Spinach ................... 176

Tomato .................... 179

Seedlings .................. 182

Part V. Fungi affecting Cereal and Forage Crops

Oats ....................... 187

Wheat $\ldots \ldots \ldots \ldots \ldots \ldots \ldots \ldots . . . .64$

Indian Corn
Sorghum and Broom Corn ... 214

Alfalfa .................... 217

Clover ..................... 219 
Nothing illustrates so practically and satisfactorily the importance and value of scientific investigation as the results obtained by recent experiments in spraying with arsenites for the destruction of insects, and with the copper solution or Bordeaux mixture for the treatment of fungous diseases. After long and patient study and experiment, scientific experts have discovered several causes of the failure of the fruit crop, and have recommended remedies which are proving effective and reliable.

These discoveries are of inestimable value, since without the remedies suggested the spread oi diseases and the ravages of injurious insects would soon have put an end to several branches of the fruit industry.-W. C. Barry.

The day is not far distant when fungicides, and the means of applying them, will be as much a part of the equipment of a first-class farm-particularly one devoted to fruit or truckas is the cultivator or market wagon.-B. D. Halsted.

We shall conquer when we know how. When we, with open eyes and unstopped ears, as true students of nature, acquire the knowledge within the possibilities of our reach, we shall be able rightfully to assert our royal authority and effectually to have dominion over every living thing that moveth upon the earth.-T. J. Burrill.

The time is rapidly approaching when a farmer or gardener will as little dare to neglect the study of the physiology and pathology of plants, as a surgeon dare practice without a knowledge of anatomy, or a sailor hope to become a captain without studying navigation. $-H$. Marshall Ward. 


\section{PREFACE}

The fungous diseases of cultivated plants inflict annually upon Aperican agriculture an enormous loss, a large proportion of which might be saved by the application of the various methods of prevention and remedy now known to be available. The purpose of this book is to bring together in easily accessible form, the information concerning the injuries, life-histories, characteristics and preventives of these diseases, now widely scattered through scores of periodicals, bulletins, reports and transactions. In preparing it, free use has been made of all accessible writings upon the subject, a list of which would include the contributions of nearly every American economic mycologist, and of many in other lands. It pretends only to the dignity of a compilation in which the compiler has utilized both the facts and very often the language of others.

It would be difficult to find, in the annals of agriculture, an instance in which knowledge of the highest practical value, concerning a subject of first importance in the successful production of the fruits of the earth, has been so rapidly evolved, as has been the case during the last decade, in the investigation of plant diseases and their remedies. Scarcely ten years have passed since there were barely half a dozen scientific men in the United States working upon these problems, from an economic standpoint. Of these, perhaps no one was doing so much, both in original investigation, and in urging the necessity that such studies be fostered by the State and general government, as Professor T. J. Burrill, of the University of Illinois. In 1886 Hon. Norman J. Colman, Commissioner of Agriculture, recognized the importance of the subject, by establishing a mycological section of the botanical division of the Department of Agriculture, and appointed Professor F. LamsonScribner to take charge of the work. The wisdom of creating the section was soon made manifest to the public at large, by Professor Scribner's demonstration of the practicability of preventing the ravages of the black rot of grapes, and other mala- 
dies of cultivated crops; and the Department has been, erer since, the chief center of interest in the development of knowledge upon the subject. In 1888, Professor Scribner resigned, for a professorship in the University of Tennessee, and was succeeded by Mr. B. T. Galloway, under whose administration the mycological section has been elevated to the Division of Vegetable Pathology, and has constantly increased in efficiency and usefulness, now having a corps of trained experts who are doing much to alleviate the ills of American agriculture.

When, in 1888, the experiment stations were established in the various States, the subject of plant diseases was at once recognized as one of the important lines of work-it being, in fact, specially mentioned in the organic law upon which they were founded-and in many stations, investigators at once began work upon the problems involved. Although scarcely six years have since passed, results of immense practical importance have already been obtained in these investigations and experiments-such as the demonstration of the value of the hot water treatment for grain smuts; of the effects of the Bordeaux mixture, and other fungicides, in preventing potato blight and rot, as well as the plum leaf-spot, raspberry anthracnose, apple scab, pear leaf-blight, and many other maladies; of the nature of various onion diseases, and methods of their prevention; and of the final discovery of the cause and cure of the potato scab. It is safe to say that, had the experiment stations done nothing more for agriculture than to obtain these and other similar results concerning plant diseases, the money spent upon them by the government would have been wisely invested.

The authors, in connection with whose publications the illustrations on the following pages originally appeared, are indicated in the following list: After Arthur, figures 78, 79; Atkinson, figure 53 ; Bailey, plates II, XI, figures 10, 11, 21, 32, 33, 36, 37, 39 ; Beach, plates VI, XIV, XV; Burrill, figure 87; Chester, plate IX, figures 9,88 ; Clinton, figures 47,48 ; Dudley, plate XIII, figures 22, 23, 65, 66; Miss Detmers, plates I, XII ; Fairchild, figures 34, 54; Farlow, plate III, figure 7; Galloway, plates IV, VII, figures 8, 31; Garman, figures, 16, 18, 19, 49 ; Halsted, 17, 20, 24, 46, 57-60, 64, 70-72, 75, 76; Miss Howell, figures 89, 90 (in part); Jones, figure 73; Kinney, plate XVI; Kellerman and Swingle, figures $\% 7,80,81$; Lamson, plate V; Lugger, figure 2; Maynard, plate X; Pammel, figure 90 (in 
part); Scribner, figures 38, 42-44, 50-52, 61-63; Seymour, 45, 86 ; E. F. Smith, plate VIII ; W. G. Smith, plate XVII ; Sorauer, figures 13,14 ; Thaxter, figures $56,67-69$; Tulasne, figure 84 ; Waite, figure 15 ; Ward, figure 6.

I have aimed to treat of only the more destructive and wide-spread fungous diseases, especially those for which practical remedies are known; and have endeavored to give such a concise account of the more important facts concerning these as will enable the cultivator to combat them intelligently. A few of the paragraphs in the following pages have already been printed in my series of articles on Plant Diseases in the National Stockman and the American Agriculturist; and in a few other instances I have drawn upon my previous writings. I desire also to express my-obligations to the directors and other officers of a number of experiment stations-notably those of Connecticut, Cornell University, Delaware, Kentucky, Massachusetts, New York, New Jersey, New Hampshire, Ohio, RhodeIsland, and Vermont-for the use of plates of illustrations.

C. M. W.

New Hampshire College of Agriculture and Mechanic Arts. Durham, January, 1894. 



\section{FUNGI AND FUNGICIDES}

\section{INTKODUCTION}

Cultivated plants are beset by many enemies. Some of these belong to the animal, and others to the vegetable kingdom. Of the former the insects, and of the latter the parasitic fungi are by far the most important. By the development of these parasitic fungi upon growing crops the peculiar maladies known as fungous diseases are produced; and to these diseases American agriculture annually sacrifices a large percentage of her products. The money value of the loss thus sustained is believed, by those who have studied the subject, to amount to hundreds of millions of dollars yearly.

It is difficult to determine definitely the amount of damage inflicted over a wide area upon a given crop by its fungus enemies, but it is safe to say that in most cases it is much greater than is ordinarily supposed. The following examples will serve to illustrate the magnitude of the loss in the case of certain crops.

In 1886 Commissioner N. J. Colman, of the United States Department of Agriculture, after careful estimates, stated: "We may safely assume that the value of the corn and wheat annually destroyed in this country by diseases induced by fungi is not less than $\$ 200,000,000$." The average annual loss due to the rust of wheat in Illinois alone has been estimated, by Professor T. J. Burrill, 
at nearly half a million dollars; and careful estimates made by authoritative observers in widely separated States indicate that the average yearly loss of oats in the United States due to smut equals, or exceeds, one-tenth the entire crop. Professor Kellerman estimated the loss in Kansas, in 1888 , at $\$ 1,382,328.31$; and in 1889 , at $\$ 850,534.76$. The loss in Indiana from the same cause, in 1889, was estimated by Professor Arthur at \$797,526; and in 1890 , at $\$ 605,35 \%$.

It is probable that fruits suffer an even greater proportionate injury than do the grains. "The blights and rots of the fruit plantations," said Professor Burrill, several years ago, "would, if exactly and certainly expressed in dollars and cents, frighten cultivators from their business." The loss from apple scab, throughout most of the apple-growing regions of the country, ranges from one-sixth to one-half of the entire product:- The strawberry blight, in many localities, often ruins crops of this luscious fruit. The rots and mildews affecting grapes have led to the extermination of hundreds of vineyards. The loss of peaches from the brown rot on the Chesapeake and Delaware peninsulas, in 1888, was estimated by competent observers at from $\$ 400,000$ to $\$ 600,000$. Similar statements could be made concerning nearly all our fruits.

The vegetable and field crops, the flowers and ornamental plants, and even the shade trees, do not fare much better. Nearly all have enemies that cause serious damage. Over a large section of country the usual loss of potatoes from fungus enemies varies from ten to forty per cent. of the crop.

\section{THE DEVELOPMENT OF PARASITIC FUNGI}

To illustrate the life history of the fungi causing the fungous diseases of growing plants, we will begin with a familiar example of regetable life-the Indian 
corn plant. When a kernel of corn is placed in a warm, moist soil, it germinates by sending out a pointed tube, called the radicle, or first root. This pushes into the soil and, after a time, produces other roots, which branch off in various directions. Soon after the radicle starts, the little plant also sends upward to the air its minute coiled leaves. While germinating; the young plant is nourished by the food stored up in the starchy portion of the corn kernel, but soon after the leaves expand in the sunlight this source of food is exhausted, and thereafter the plant relies upon its own resources for the materials of growth. By means of the continually developing rootlets, it is able to draw from the soil certain chemical compounds, such as water, potash, phosphoric acid, etc., which are taken up through the stem and distributed to the leaves, where, by the action of the sunlight upon the chlorophyll-or the green portion of the leaf-they are combined with the carbonic acid of the air, and these simple chemical substances are changed from inorganic to organic compounds, forming starch, sugar, and various other products. The plant continues growing, storing up in its leaves and stem more and more of these highly organized materials which it produces as it develops. It finally reaches a point where it begins preparing for reproduction; on the middle or lower portions of the stem it sends out its pistillate, or silky blossoms, and on the upper it produces the staminate, or tassel flowers. The pollen from the latter falls upon the former, and fertilizes the ovaries of the embryo kernels. These then begin to develop, and much of the starchy and other organic matter stored in the stem and leaves is transferred to the cob and kernels. The latter finally mature, and the cycle of vegetable life is complete.

This is a fair illustration of the life-history of the higher plants. Such plants are especially distinguished 
by the presence of chlorophyll, and the ability to convert the inorganic elements of the soil and air into highly organized compounds. But such plants form only a part of the vegetable life of the globe. There are vast numbers of the so-called lower plants, like the toadstools, mushrooms, molds, mildews, rusts, smuts, blights, and similar organisms, which are classed together under the common name of fungus. The plural of fungus is fungi-pronounced funji-or funguses. These fungi differ greatly from each other; some rank comparatively high in the scale of existence, and others rank low.

As an illustration of the higher fungi, we may take one of the mushrooms so common in our fields and

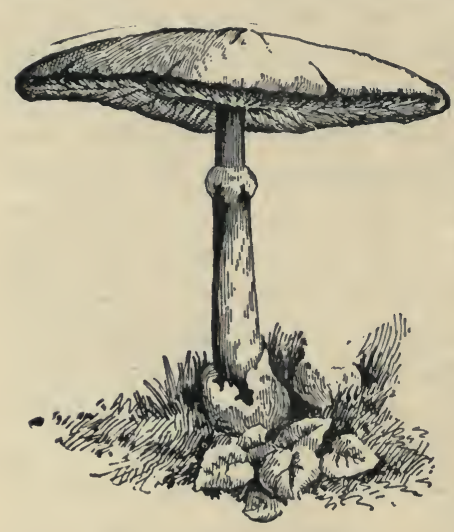

FIG. 1. MUSHROOM. woods. This plant reproduces by means of spores - minute bodies, corresponding in function to the seeds of higher plants. When one of these spores falls upon a moist soil, rich in decaying organic matter, it germinates by sending out a little tube -much as the kernel of corn sends out its germinating radicle-and this tube, after penetrating the soil a short distance, sends out side branches, which push about between the decaying organic particles, absorbing nourishment from them. These branches, in turn, send out other branches, and these form what is called the mycelium, or regetative portion of the fungus; this continues developing beneath the surface for some time. Finally an unusual development of mycelium takes place at one or a few points, and from these there are rapidly produced a few 
mushrooms, which may be sent up into the air above the soil surface in a single night. Each mushroom (Fig. 1) consists of a stem commonly surmounted by an umbrellalike cap, on the under side of which are many thin vertical plates. Between these plates vast numbers of spores are soon produced, to fall to the ground, or to be wafted hither and thither by the winds. As soon as the spores are ripe the fungus dies. It will be noted that this plant has no chlorophyll, and is simply nourished by dead and decaying organic matter. Fungi like this are said to be saprophytes, or saprophytic, a word meaning living on decaying materials. Such plants, as a rule, do no direct mjury to other kinds of vegetable life.

There are many kinds of fungi which, instead of living upon dead or decaying organic matter, develop at the expense of other living organis ms. Consequently these are said to be parasitic in their nature. Some of these live within the bodies of animals, often kill- Fig. 2. сHINCH BUGs AFFECTED ing their hosts, and others

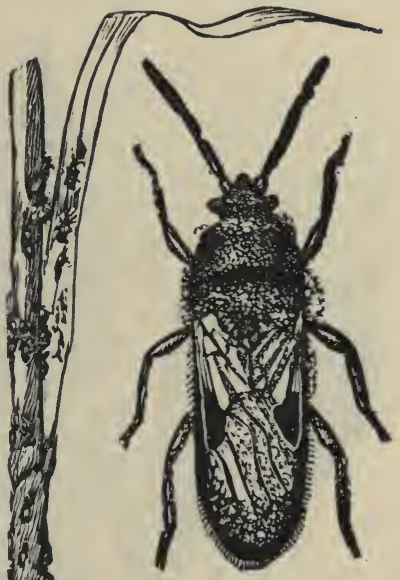
live within the tissues of the higher plants. A good example of the former is seen in the fungus which destroys chinch bugs, represented in Fig. 2. A number of dead bugs are shown on a wheat stalk on the left, while a single bug, much magnified, corered with the fungus, is represented at the right. This fungus belongs to a genus of plants called by botanists Entomophthora. To illustrate the manner of development of the parasitic fungi affecting higher plants, we may take the 
downy mildew which causes the well-known rot of the Irish potato. It is now believed that this disease does much less damage in America than has been commonly supposed, the injury attributed to it being often due to other fungi, but it is sometimes destructive, and its lifehistory has been carefully studied.

The first indication of the presence of the downy mildew in the potato field usually is the appearance of

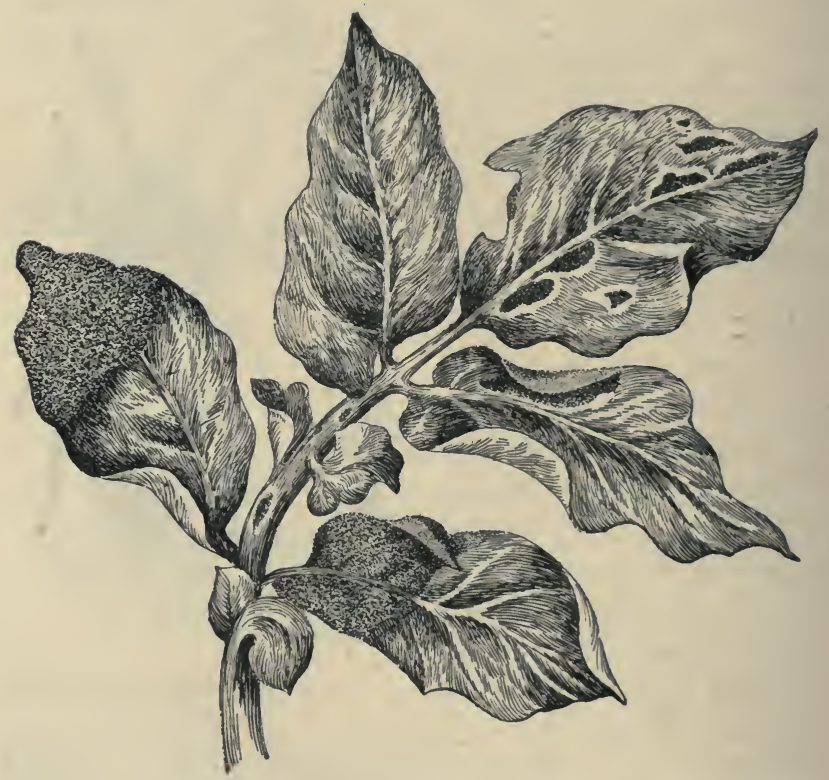

FIG. 3. DISEASED POTATO LEAF.

brownish spots upon the leares. As the disease progresses these spots gradually enlarge, finally involving the whole leaf, which turns dark brown or blackish. 'Then neighboring leaves become affected, and the whole plant eventually wilts and dies. 
If one looks closely at the under surface of the leaf beneath the brown spots, he will see, in case this fungus is present, a whitish velvety mold. By making a thin cross-section of the leaf at this point, and putting it under the microscope, an appearance similar to Fig. 4 will be seen. At the right is one of the long pointed hairs which grow naturally upon the under surface of the healthy leaf; next to this toward the left is another peculiar leaf-hair with a club-like tip; and beyond this

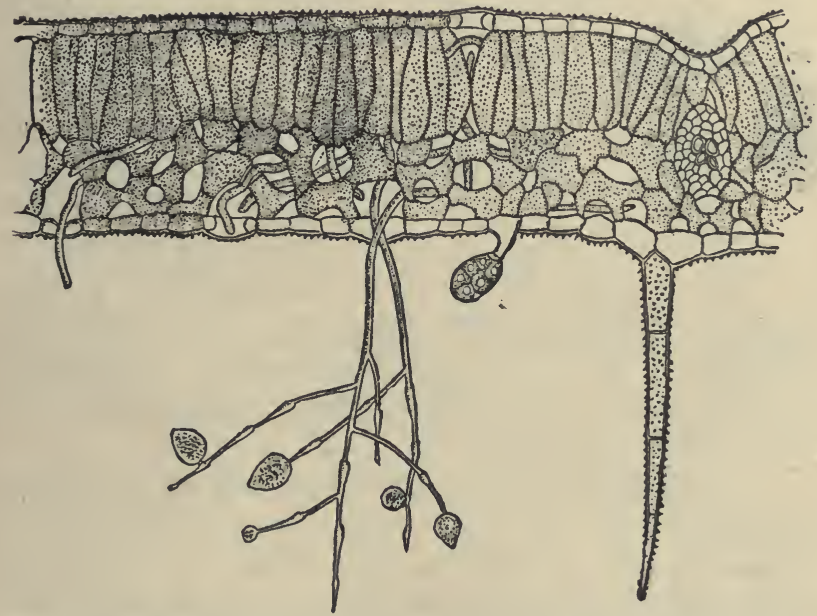

FIG. 4. SECTION OF POTATO LEAF SHOWING DEVELOPMENT OF MILDEW.

project the hyphæ, or fruiting threads of the fungus, which give off branches on which are borne small oval bodies. The latter are the spores, or conidia, of the fungus. They are uhe bodies by means of which the fungus reproduces itself, and are developed on the infested leaves in enormous numbers.

These conidia are easily dispersed by slight air currents, and are carried far and wide cn the wings of the 
wind. When one of them falls upon a moist potato leaf it germinates by a very peculiar method: The inside of the spore is composed of a granular substance which at this time divides into several individual particles, that escape through an opening in the smaller end of the spore wall, as seen in b, Fig. 5. Each of these particles now develops two minute hair-like projections, called cilia, as seen at $c$, by means of which it swims around in the drop of water; these are called swarm-

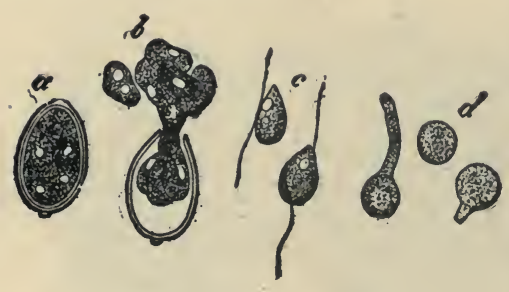

Fig. 5. POTATO MILDEW. spores, or zoöspores. After a short time these swarm-spores come to a rest, absorb the cilia, and change from the oval shape to one more spherical $(d)$; each then germinates by sending out a little $a$, conidium; $b$, same, with contents escaping;
$c$, swarm spores; $d$, same, come to rest and $\mathrm{m}$ in at ing tube, $c$, swarm spores; $d$, same, come to rest and something as a kernel
germinating. of corn sends out its germinating radicle, as shown in the two figures beside $d$.

In case these swarm-spores germinate on the surface of a potato leaf on or near to one of the breathing pores, or stomata-the peculiar openings with which both surfaces of most leaves are provided-the germ tube passes to the interior of the leaf through it, as shown at $a$, Fig. 6. If no breathing pore is in the immediate vicinity, the germinating spore bores through the cell wall, as shown at $c$.

After the parasitic fungus has thus entered the inside of the leaf it derelops rapidly at the expense of the tissues of the latter. It pushes its threads, or hyphoe, about between the cells, choking up the cavities which occur in the healthy leaf, and absorbing the contents of the cells. In many species of Peronospora the 
threads that run between the cells send into the cells themselves little processes called "suckers," or haustoria, which assist in absorbing the cell contents. Thus, in the downy mildew of the grape this occurs in a way illustrated at Fig. \%. These threads running through the leaf lead to the disorganization of its tissues, causing the cells to collapse and turn brown. When they have

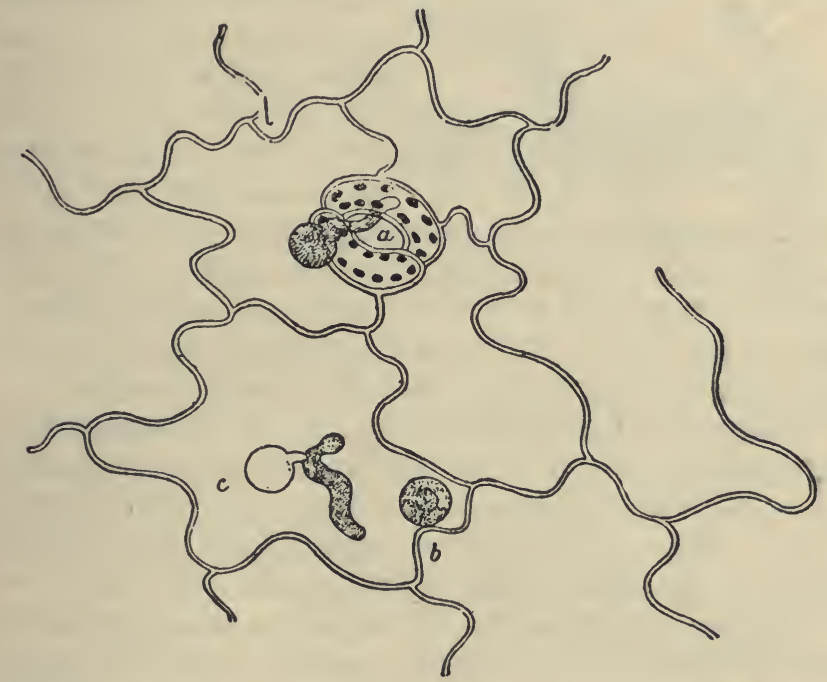

FIG. 6. SURFACE OF POTATO LEAF GREATLY MAGNIFIED, SHOWING GERMINATING SPORE ENTERING BREATHING PORE AT $a$, AND GOING THROUGH EPIDERMIS AT $c$.

developed to a considerable extent they collectively form the mycelium of the fungus.

After the Peronospora plant has reached this stage in its existence it is ready to prepare for reproduction. It sends out through the breathing pores of the leaf branching threads, and on these develops the conidia, as already described.

By means of these conidia, which are produced in great abundance, and the swarm-spores originating from 
them, the fungus is able to multiply with marvelous rapidity during the warm, damp weather most favorable to its growth. "In an ordinary potato field the abundant foliage, wet with rain and full of juices such as would favor the growth of the mycelium, is swayed by the wind, and leaf flaps upon leaf over the whole area; quite apart from the wind-blown conidia,

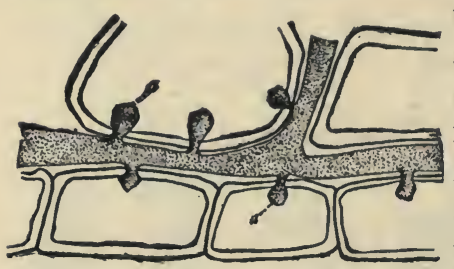
the active zoöspores can soon spread from any one center, and at once infect new leaves. In a few hours fresh disease-spots are developed, each putting forth new crops of Fig. 7. SECTION OF LEAF SHowing conidia, which again gerMYCELIUM OF FUNGUS, MAGNIFIED. minate and send out zoöspores, and so on." Under these conditions it is easy to see that the attack may be sudden and destructive.

Besides these conidia, or summer spores, many parasitic fungi develop in autumn certain spores, by means of which the fungus passes through the winter. The latter are usually better protected than the conidia. They are sometimes called winter-spores.

Besides the saprophytic and parasitic fungi discussed above, there are some which partake of the nature of both, belonging to one class during a portion of their development, and to the other during the rest. For example, the black rot of grapes is at first a true parasite attacking the healthy parts of the vine, but it completes its growth as a saprophyte, living upon the decaying berries.

RELATION OF THE WEATHER TO FUNGOUS DISEASES

There is a common idea that the weather is responsible for a large proportion of plant maladies. In an indirect way this is often true, but the condition of the 
atmosphere never directly causes a fungous disease. Such diseases, as already indicated, are produced by minute plants, which never arise spontaneously, but always from some spore, or other reproductive form of a previously existing plant of the same species. But weather conditions may be favorable to the rapid development of these fungi, and so indirectly cause the diseases.

\section{METHODS OF STUDYING FUNGI}

The successful study of the minute characteristics of most fungous diseases requires the use of a compound microscope. These, however, can be obtained for a comparatively small amount, and will well repay the investment in the wonders revealed. By the aid of some such little book as Phin's "How to Use the Microscope," or Bausch's "Manipulation of the Microscope," almost anyone can learn how to manipulate a microscope, and can exarnine the microscopic characters of the various fungi affecting crops. One desiring to undertake such study would find the following books helpful :

Bennett \& Murray: Cryptogamic Botany.

Burrill : Parasitic Fungi of Illinois.

Plowright: British Urediniæ and Ustilaginiæ.

Scribner : Fungous Diseases of the Grape and Other Plants.

Smith : Diseases of Field and Garden Crops.

Ward : Diseases of Plants.

The bulletins of the United States Department of Agriculture, especially the Journal of Mycology, and of the various experiment stations, will also prove very useful.

\section{METHODS OF DISTRIBUTION}

There are many ways in which fungous diseases are distributed, although the commonest one is by means of 
the various kinds of summer spores. With the great majority of diseases these are produced in countless numbers, and as they are wafted hither and thither by every breath of wind, are washed from leaf to leaf and from leaf to root by rains, and germinate quickly in their new situations, they are able to spread infection with marvelous rapidity. They are also, no doubt, often carried from place to place by insects and birds, adhering to some part of their bodies, especially the feet.

The various other kinds of spores produced by the fungi discussed in the following pages are also distrib. uted by similar agencies. Some of the smuts, as well, no doubt, as many other diseases, are often spread through the field in barnyard manure; and in cases likc the onion smut, the spores may be washed, with loose soil, from higher to lower levels. The spores of certain grain smuts appear to be able to pass from diseased to healthy kernels during the process of threshing, and, in some cases, the disease may be spread by means of hoes and other implements used in cultivation.

In diseases like the scab and blight, or rot of potatoes, the mycelium of the fungus is often distributed in the tubers used for seed, thus being ready to infect the new crop as soon as it gets well started.

\section{METHODS OF PREVENTION}

There are many ways in which the injuries of fungous diseases may be prevented. Among the more important of these are the following:

Fertilization and Cultivation.-As a general rule,-not, however, without important exceptions,plants weakened in vitality are more subject to the attacks of parasitic fungi than those in vigorous growth. Consequently methods of cultivation and fertilization which tend to produce rapid development and early maturity, are to be adopted as far as practicable. 
Selection of Resistant Varieties.-It has long been observed that with many crops certain varieties are more liable to fungous diseases than others. The reason of this, in many cases, is not well understood, but the fact will lead the careful cultivator to select such varieties as prove most resistant, other things being equal, in his locality. Dr. B. D. Halstead has recently shown that plants with variegated foliage are much more subject to fungus attack than those with green leaves.

Rotation of Crops.-The spores of the great majority of parasitic fungi pass the winter on or in the soil where the crop attacked was grown, and if a crop of the same kind is planted there the next season it is almost certain to be infested. The onion smut is a striking example of this. In consequence, the proper rotation of crops is not only desirable, but often imperatively necessary. The rotation should be so arranged that each crop will not be liable to attack from the diseases of the preceding crop.

Clean Culture.-Injurious fungi may be largely destroyed by keeping the farm premises clean and free from weeds and rubbish. Burning potato tops, old tomato vines, and similar refuse, will destroy millions of spores. Some fungi which infest cultivated crops also grow upon weeds, and, hence, keeping the ground free from the latter may prove of great benefit to the former. Care should also be taken not to distribute the spores by means of stable manure.

Mechanical Exclusion.-It is often practicable to prevent the spores from reaching the crop by methods of mechanical exclusion. The most familiar example of this is to be found in the practice of bagging grapes to prevent their rotting. Small paper sacks are tied over the bunches as soon as the fruit is well formed, and allowed to remain until it ripens. The sacks exclude the rot spores, and also prevent insect attack. 
Hand Picking.-With diseases like the brown rot of peaches and plums, plum pockets, etc., much may be done in reducing injury by persistent hand-picking of the affected parts, which, of course, should be burned or buried deeply in the soil.

Use of Non-infected Seed.-Numerous fungous diseases start from the seed. For instance, the potato rot exists in seed potatoes, and so infects the new crop. In such cases care should be taken to obtain seed not so infected, or, when possible, so to treat the seed that the spores are destroyed.

Destruction of Alternating Forms.-As shown on other pages, some of the rusts exist in two or more forms on different host-plants. For instance, the apple rust has one form that produces "cedar balls" on cedar trees. The destruction of the latter will prevent the development of the former.

Use of Fungicides.-The most practicable way of preventing the great majority of the fungous diseases of cultivated crops is by the use of fungicides (a word meaning, literally, killers of fungi). These are discussed more fully under the following heading. The majority of them are applied externally to plants by spraying or dusting. In such cases they may act in either or both of two ways: (1) By directly destroying any fungus spores present at the time of application; and (2) by remaining on the surface in a condition to destroy, either before germination or during that process, any spores that may light upon the plant thereafter.

\section{THE IMPORTANT FLNGICIDES}

The following list includes the fungicides that have proved of practical value up to the present time. It is a list, however, that will probably be exterded during the next decade, as experiments are constantly progressing to learn the fungicidal value of many other substances. 
Water.-The use of water heated to $132 \frac{1}{2}^{\circ} \mathrm{F}$. has recently come into practice to destroy the spores of grain smuts in or on the seed. The water should not get above $135^{\circ}$, nor below $130^{\circ}$, while the seed is immersed. Full directions for this treatment will be found in the discussion of wheat and oats smuts.

Bordeaux Mixture.-This fungicide originated in France, and has become one of the leading combinations of copper salts. Since its introduction into America there has been a constant tendency to dilute the mixture more and more. The results from the diluted mixtures hare been apparently as good as from those of full strength, and, of course, the cost has been propertionately lessened. The different formulas are indicated below :

Original Formula.-Dissolve six pounds of copper sulphate in one gallon of hot water in an earthen or wooden vessel. In another vessel slake three pounds of fresh lime in one gallon of water. Strain the latter and add to twenty gallons of water. Now pour in the dissolved copper sulphate and mix thoroughly. Keep the mixture stirred while using.

Half-strength Formula.-In 1889, while at the Ohio Experiment Station, I experimented with potato blight by diluting this mixture a little more than half, using six pounds of copper sulphate and four pounds of lime to a barrel (fifty gallons) of water, instead of twenty-two gallons. This was applied to a number of plants besides potatoes, and, apparently gave as good results as undiluted mixtures. The same formula was also successfully used in 1890 , and has since been quite generally adopted, being now recommended by the United States Department of Agriculture. Mr. Galloway suggests the following method of procedure :

"In a barrel that will hold forty-five gallons dissolve six pounds of copper sulphate, using eight or ten gallons 
of water, or as much as may be necessary for the purpose. In a tub or half barrel slake four pounds of fresh lime. When completely slaked add enough water to make a creamy whitewash. Pour this slowly into the barrel containing tine copper sulphate solution, using a coarse gunny sack stretched over the head of the barrel for a strainer. Finally fill the barrel with water, stir thoroughly, and the mixture is ready for use. Prepared in this way the cost of one gallon of the mixture will not exceed one cent, the price of copper sulphate heing seven cents per pound, and lime thirty cents per bushel. In all cases it is desirable to use powdered copper sulphate, as it costs but little more and dissolves much more readily. It is highly important also that fresh lime be used."

Third-strength Formula.-In 1891 Mr. W. J. Green, of the Ohio Experiment Station, used on apples, plums, pears, cherries, raspberries, etc., a still more dilute mixture, viz., four pounds of copper sulphate and four pounds of lime to fifty gallons of water, and obtained very good results. The cost of the copper sulphate in a barrel of this mixture is less than one-third the cost of that in a barrel prepared according to the original formula.

A still more dilute mixture is recommended by the Rural New Yorker, and probably, in some cases, is as effective as any of the above, while also cheaper. It is "one ounce of copper sulphate and three-fourths of an ounce of lime to each gallon of water; that is to say, two pounds of copper sulphate and one and one-half pounds of lime to thirty-two gallons of water." A special advantage of the Bordeaux mixture is, that London purple or Paris green can be added to it, making a combined insecticide and fungicide.

Care should be taken not to use the Bordeanx mixture on fruit crops too late in the season. Traces of it 
remain for some time, notwithstanding numerous rains, and are liable to cause unnecessary suspicions when on marketed fruit. When a fruit crop requires treatment within a month of the time of picking, it is better to substitute some fungicide like eau celeste or carbonate of copper, but it is doubtful if even these combinations should be applied so near the time of the fruit harvest. With nearly, if not quite, all of our fruit diseases, the treatment should begin early and not continue too late.

It sometimes happens that traces of Bordeaux mixture remain upon the fruit, even when a considerable interval elapses between the last application and the ripening of the fruit. Such traces may be easily removed by dipping in a solution made by adding two gallons of cider vinegar to ten gallons of water. A good way is to hare three tubs, one holding the vinegar mixture, and the other two pure water. Then place the grapes or other fruit in wire baskets holding fifteen to twenty pounds, dip them in the vinegar tub for five minutes, and then rinse in the two tubs of clear water, afterwards spreading the fruit on frames or shelves, something like those used in fruit evaporators. Grapes can be treated in this way on a large scale for six cents a hundred pounds, and their appearance for market is not injured to any appreciable extent.

The Bordeaux mixture must be kept well stirred in the reservoir during application. A paddle in the barrel, something like that of an old-fashioned churn, is one of the most efficient agitators. The addition of enough soap to make a slight suds has been recommended, as causing the mixture to spread more evenly over the plants.

Eau Celeste.-This is made by dissolving two pounds of copper sulphate in six or eight gallons of water in an earthen or wooden ressel (such as the large crocks used for butter, or wooden pails or tubs), then 
adding one quart of ammonia and mixing with fifty or sixty gallons of water.

Modified Eau Celeste.-Dissolve four pounds of sulphate of copper in ten or twelve gallons of water, and stir in five pounds of washing or sal soda; dissolve one and one-fourth pounds of sal soda in hot water, then add three pints of ammonia and dilute to fifty gallons of water.

Carbonate of Copper.-This is commonly used in the form of an ammoniacal solution, made by dissolving four ounces of carbonate of copper in two quarts of ammonia, and then adding to a barrel of water. The carbonate will dissolve more readily if mixed with water enough to form a paste before it is added to the ammonia. It is a simple fungicide, easy to make and apply, and as it is a clear solution there is no trouble with its clogging nozzles. It has been successfully used to prevent apple scab, various mildews, etc.

Inasmuch as commercial copper carbonate is rather expensive, costing thirty-five to forty cents per pound at wholesale, Professor F. D. Chester advises that it be prepared at home according to the following method, in which case it costs, for materials, but fourteen cents per pound:

"Dissolve in a barrel twenty-five pounds of copper sulphate in hot water. In another barrel dissolve thirty pounds of sal soda in hot water. Allow both solutions to cool, then slowly pour the solution of sal soda into the copper sulphate solution, stirring the same. Fill the barrel with water and allow the precipitate of copper carbonate to settle. Upon the following day siphon off the clear supernatant liquid, which contains most of the injurious sodium sulphate in solution. Fill the barrel again with water, and stir the precipitate vigorously into suspension; again allow the precipitate to settle, and again on the following day siphon off the clear 
liquid. This operation washes the carbonate free of most of the sodium sulphate which contaminates it. Make a filter of stont muslin, by tacking the same to a square wooden frame which will just fit over the open top of the second barrel, letting the muslin hang down loosely so as to form a sack; through this filter the precipitate, so as to drain off the excess of water, and as the filter fills remove the precipitate, and allow it to dry in the air, when it is ready for use. The operation is not troublesome, and can be carried on in connection with other work."

Potassium Sulphide.-Dissolve one-half ounce of potassium sulphide (liver of sulphur) in one gallon of hot water. When cold apply in a spray. Used to prevent gooseberry mildew and similar diseases. Commercial lirer of sulphur costs fifteen to twenty cents per pound.

Soda Hyposulphite.-Dissolre one-half ounce, or one ounce of soda hyposulphite in ten gallons of water. This is recommended by some for gooseberry mildew and apple scab, but it is not in general use.

Sulphate of Copper.-Besides its use in combination with other substance, copper sulphate is often applied to vines and trees early in spring to destroy the winter spores of fungi. For this purpose it is used in a simple solution made by dissolving two pounds of the copper sulphate in fifty gallons of water.

Copper Chloride.-This is a greenish crystalline salt of copper, readily soluble in water, which has been recently tested as a fungicide at the Cornell University Experiment Station, with encouraging results. It is said to cost, at retail, about ten cents an ounce, or fiftý cents a pound. Used at the rate of one and one-half ounces to twenty-two gallons of water it injured peach and apple foliage. So little is now known of it that no practical recommendations can here be made, other than that it is worth experimenting with. 
Sulphur.-Flowers of sulphur form a valuable fungicide to use against various mildews and other diseases. The powder may be applied directly to the surface of the plants to be protected, or used as a wash, or in fumes.

\section{COMBINING FUNGICIDES WITH INSECTICIDES}

It is often desirable, in applying the fungicides used in spraying, to combine with them certain insecticides, to destroy insects attacking the crop at the same time. The advantages of this, in saving time and expense, are obvious. The following two combinations have been found practicable :

Bordeaux Mixture and Arsenites.-Add four ounces of London purple or Paris green to fifty gallons of Bordeaux mixture. This is one of the rery best combined insecticides and fungicides. It can be used safely and effectively upon a great variety of cropssuch as potatoes, for Colorado beetles and blight; apples and pears, for insects and scab; and plums and peaches, for curculio and leaf or fruit diseases. To use upon fruits the Green formula is probably the best, as too large an amount of copper sulphate occasionally prerents the perfect development of apples and pears. The remarks on page 16, concerning late applications of the Bordeanx mixture, are equally applicable to this combination.

Copper Arsenic Solution.-The Ohio Experiment Station recommends the following combination: Copper carbonate, six ounces; Paris green, four ounces; ammonia, two quarts; lime water, fifty gallons. "The copper carbonate and Paris green may be mixed and dissolved in the ammonia (more or less ammonia will be required, according to the strength), after which add the lime water. By lime water is here meant clear lime water made by dissolving as much lime in water as it 
will take up. One-fourth of a pound of lime to a barrel of water is as much as is required for the purpose of preventing the injury to the foliage which the Paris green might cause. A convenient method is to put several pounds of lime in a barrel, and then fill with water; after stirring vigorously allow to settle, when the clear water may be used. The barrel may be filled with water each time before going to the orchard, and allowed to stand while gone." Only sufficient ammonia to dissolve the copper carbonate and Paris green should be used, and no more lime than directed.

Care must be taken in combining the arsenites with other fungicide solutions, as one is liable thus to produce a compound very injurious to foliage. Paris green or London purple added to simple solutions of copper sulphate, or to ammonia compounds without lime, injures foliage vastly more than in simple water mixture.

\section{COST OF FUNGICIDE MATERIALS}

The approximate wholesale and retail price of the more important substances used for fungicides is indicated below :

\begin{tabular}{|c|c|c|}
\hline W & $\begin{array}{l}\text { Wholesale. } \\
\text { Per lb. }\end{array}$ & $\begin{array}{l}\text { lietuil. } \\
\text { Per lb. }\end{array}$ \\
\hline Ammonia $\left(22^{\circ}\right.$ Baume $) . . . \ldots \ldots \ldots \ldots$ &..$\$ 0.07$ & $\$ 0.20$ \\
\hline Carbonate of copper (Precipitated)... & .. .40 & .60 \\
\hline Carbonate of ammonia................... & .14 & .30 \\
\hline Liver of sulphur.................. & .. .15 & .25 \\
\hline Lime, per barrel (300 pounds)...... & $\therefore 1.65$ & \\
\hline Sorla carbonate..................... & .. .04 & .10 \\
\hline Soda hypo-sulphite............... & .06 & .15 \\
\hline soda...$\ldots \ldots \ldots \ldots \ldots \ldots \ldots$ & $.011 / 4$ & .05 \\
\hline ll phate of copper (Powdered)... & .07 to .09 & .12 to 15 \\
\hline phate of copper (Crystals)........ & .05 & .10 \\
\hline 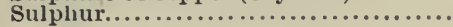 & .03 & .10 \\
\hline
\end{tabular}

\section{THE APPLICATION OF FUNGICIDES}

Fungicides may be applied to plants, either in the form of a dry powder or a liquid solution. In the former case they are usually most easily handled by means of a powder bellows-such as Leggett's powder gun- 
and in the latter by means of some form of spraying pump. In both cases it is important that they be finely divided and evenly distributed.

There are many forms of spraying pumps upon the market. In general they are of four sorts: The bucket

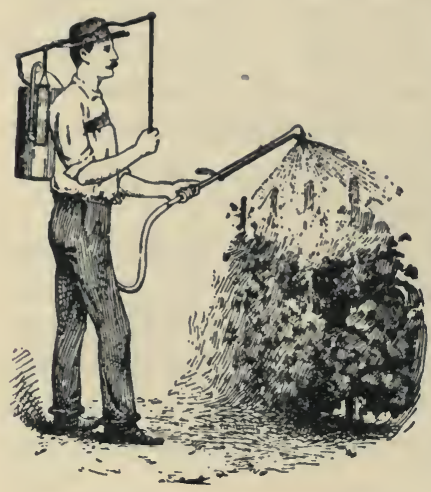

FIG. 8. KNAPSACK SPRAYER. pumps, the knapsack sprayers, the barrel sprayers, and the geared automatic machines. The form of the knapsack sprayer is shown in Fig. 8. It is useful in some cases, but in general the carrying of the reservoir and contained liquid should not be imposed on human shoulders. A convenient barrel outfit is shown in Fig. 9. The barrel has upon it a double discharge pump, to which are attached two lines of hose, provided with good nozzles, and fastened at the end to poles. Three men operate the machine, one driving and pumping, and two directing the spray.

Many different kinds of spray nozzles are also offered for sale. In several cuses, at least, each has a peculiar value for certain lines of work. Consequently the fruitgrower who dhas a variety of vines and trees to spray should own four or five nozzles, and use the one best adapted to the work in hand. Some of the best forms are the Improved Vermorel, Climax, Cyclone, Graduating Spray, Mason, and Improved MeGowen, No. $\%$

Professor L. H. Bailey uses, for bushes and vines which need to be sprayed on the under surface, the cyclone nozzle, in connection with a home-made wheelbarrow tank, as shown in Fig. 10. A piece of rubber 
tubing fire or six feet long connects the nozzle with the pump, the outer end of the tubing being tied to a light rod, so that the spray can be sent wherever desired.

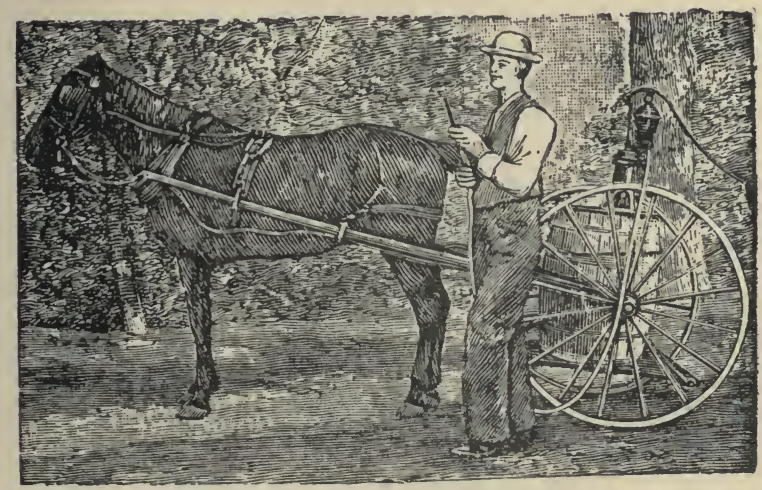

FIG. 9. THE CHESTER SPRAYING CART.

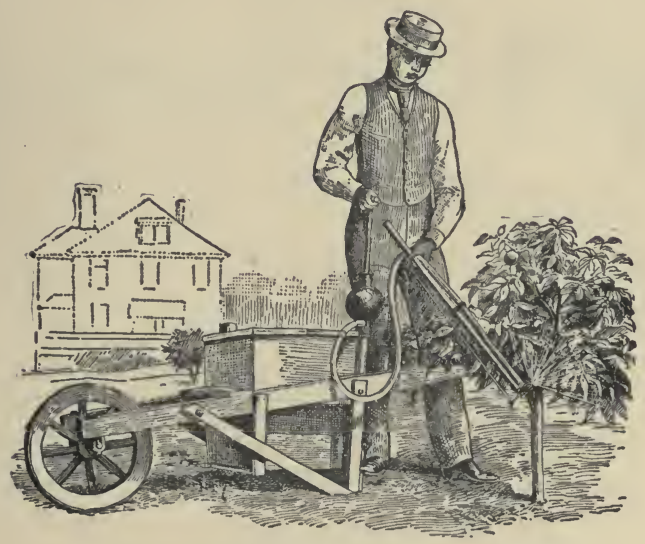

FIG. 10. METHOD OF SPRAYING BUSHES.

A fuller discussion of the subject of spraying will be found in the author's little manual entitled Spraying Crops. 



\section{PART I}

FUNGI AFFECTING ORCHARD FRUITS 


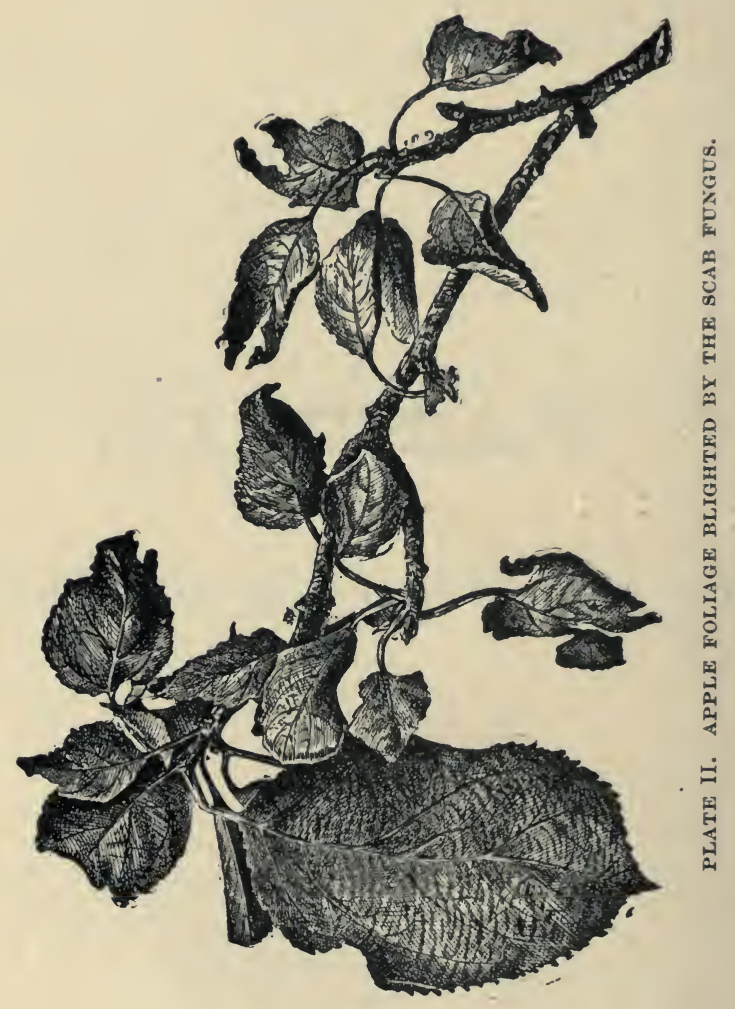




\section{FUNGI AFFECTING THE APPLE}

\section{The Apple Scab}

\section{Fusicladium dendriticum}

There is, probably, no fungous disease of fruits so familiar to the general public as the apple scab, or, as it is sometimes called, the black spot. This is due to a

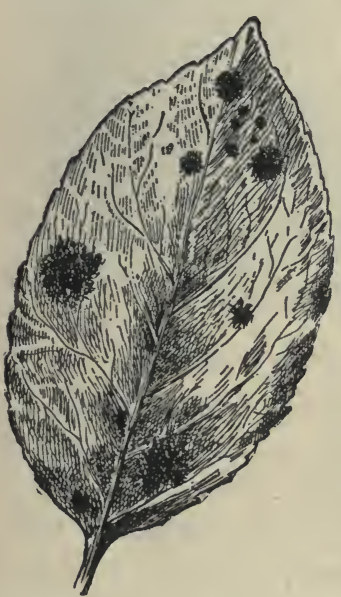

FIG. 11. APPLE SCAB SPOTS ON A LEAF.

fungus which produces the wellknown scabby spots upon the fruit, and also attacks the leaves and green shoots. It first appears upon the leaves in the shape of smoky greenish spots, more or less circular in outline. These gradually enlarge, and frequently several of them run together, so as to form good sized blotches; as they grow older their color darkens, finally becoming almost black. The upper surface of the leaf is usually affected.

Sometimes the fungus develops so rapidly on the expanding leaves in early spring as to blight them, dwarfing and killing the younger foliage. An instance of this, observed by Professor L. H. Bailey, is illustrated in 
Plate II, which represents the size of dwarfed leaves late in July, as compared with a full-grown one. In such seasons the newly formed fruit is also attacked by the fungus, which shrivels the young apples and causes them to fall off. Occasionally an entire crop is thus destroyed.

The spores, or reproductive bodies of the fungus, are produced in immense numbers on the blackened spots on the leaf and fruit, forming most abundantly dur-

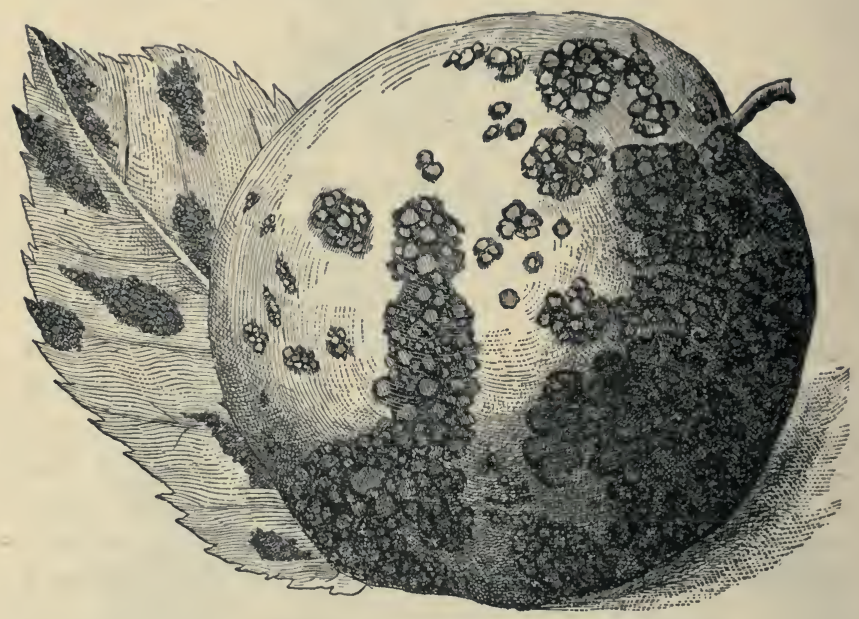

FIG. 12. FRUIT AND LEAF SPOTTED BY SCAB.

ing cool, wet weather. They are carried hither and thither by wind and rain. When they light upon a moist leaf or fruit they germinate, by sending out a little tube, and thus form a new center of disease. The spores pass the winter on the bark, twigs, and stored fruit, as well as on the fallen leaves and fruit. During the moist weather of spring they start the disease again. Besides the injury to the leaves and the destruction of the very young fruit, this disease causes serious losses 
by dwarfing and disfiguring the apples that mature. Secretary A. C. Hammond, of the Illinois State Horticultural Society, estimated the annual loss due to this disease in Illinois alone at $\$ 400,000$, and other authorities have estimated it at from one-sixth to one-half of the entire crop.

The mycelium, or vegetative portion of the scab fungus, consists of brownish cells which develop just beneath the skin of the leaf or fruit, but, as a rule, do not penetrate deeply into the tissues. After the fungus has grown in this way for some time it pushes outward, rupturing the skin ; and on the exposed surface short vertical brown threads are developed, on the tips of which the small oval spores are produced (Fig. 14). When mature the spores sepa-

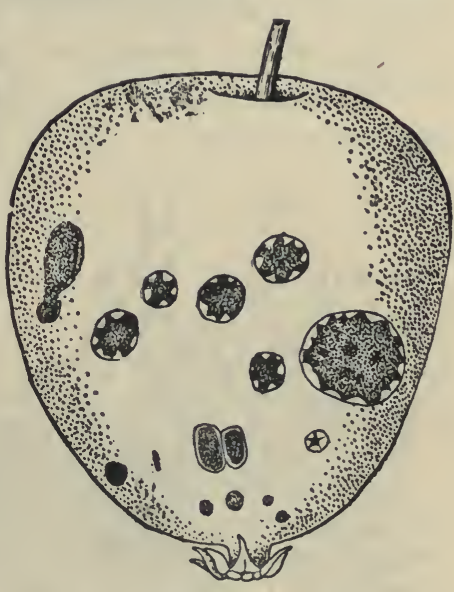

FIG. 13. SCABBY APPLE SHOWING RUPTURES IN THE SKIN. rate, and are scattered by wind and rain in all directions.

Treatment.-In spring, just before the leaf-buds open, spray thoroughly with dilute Bordeaux mixture, or else spray before the leaf-buds begin to swell, with a simple solution of copper sulphate; repeat the application of Bordeaux mixture a little later, just before the blossoms open; spray for the third time just after the blossoms have fallen, adding arsenites for the codling moth if desired; ten days after this third application spray again with the combination of Bordeaux mixture and Paris green or London purple. Do not apply Bordeaux mixture late to early ripening apples. 
Literature.-Articles concerning apple scab may be found in the following publications: Bulletin Ohio Experiment Station, IV, No. 9; Report U. S. Dept. Agriculture, 1887, pp. 341-347; First Report Wisconsin Experiment Station, 1884, pp. 45-56 ; Cornell University Experiment Station, Bulletin 48.

\section{The Powdery Mildew}

\section{Podosphoera oxyacanthce}

About midsummer one may often find on the leares and young shoots of apple, cherry, quince, peach, and

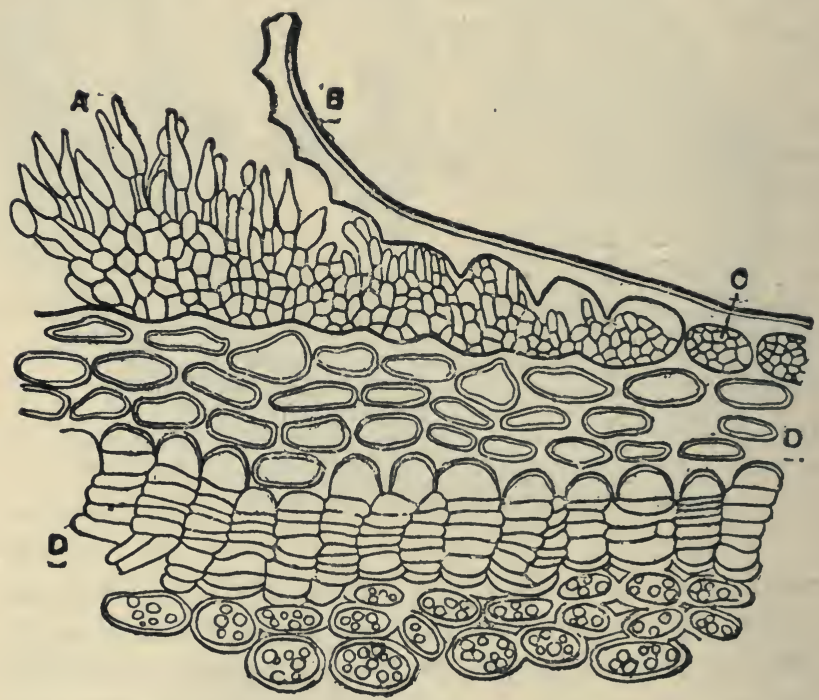

FIG. 14. SECTION SHOWING SCAB FUNGUS.

$A$, spores in position, as developed; $B$, skin of fruit turned up; $C$, parenchymalike cells of the parasite; $D$, tissues of the fruit. Much magnified.

several other trees, small round whitish blotches of mildew, which at first have more or less of a radiated appearance, due to the spreading of the threads. In a short time many of the spots enlarge so that they run 
together; and the mildew often covers the whole surface of the leaf, either as a thin coating through which the green surface can be seen, or as a thick, felt-like covering, which entirely conceals the leaf surface. This mildew is composed of a great number of minute white threads, branching in all directions, which form the mycelium of the powdery mildew fungus. In the fungi of this group the mycelium is external, $i$. e., instead of developing on the inside of the leaf of the host-plant, it develops on the outside, and in order to get nourishment

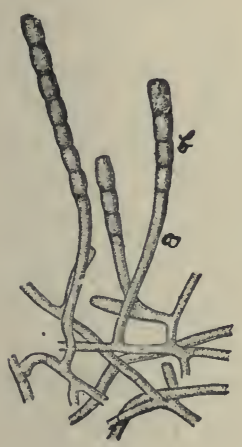

$c$

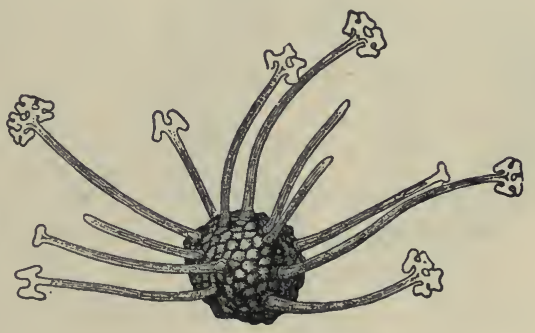

$d$

FIG. 15. APPLE POWDERY MILDEW.

$c$, Mycelium forming summer spores; $d$, winter spore case (perithecium). Magnified.

the mycelium threads send little suckers into the cells of the leaf and absorb their contents, for the benefit of the fungus. Soon after the mycelium gets well developed it assumes a powdery appearance, due to the production of great numbers of the minute white spores, called the summer spores, or conidia (Fig. $15 b$ ). These are very light, and are scattered by every breath of air. When one of them falls upon an unaffected leaf, where sufficient moisture is present, it germinates and starts the disease anew. By means of these summer spores-a 
vast number of which may develop from the mycelium of a single leaf-the fungus is able to spread very rapidly. Toward the end of summer the mycelium derelops small roind black masses just visible to the naked eye, which are the cases containing the winter spores. These cases are technically called perithecia, and when magnified resemble Fig. 15, $d$. They remain on the leaves when the latter fall in autumn, and tide the fungus over winter.

This powdery mildew may develop on either surface of the leaf, and is especially likely to appear on the leaves and stems of young shoots. It is also usually much more abundant on young trees than old ones, and is especially destructive to nursery stock; so much so, in fact, that where no treatment with fungicides takes place it often prevents the successful budding of a large proportion of the young trees. Leaves severely attacked by the fungus drop off prematurely, and so prevent the proper growth of the tree. The disease is usually most prevalent during seasons of dry weather.

Treatment. - As a rule, it is only in the nursery that this disease is sufficiently destructive to require remedial treatment. To prevent it, spray with the ammoniacal solution of copper carbonate, making the first application when the leares are about half-grown, and repeating four or five times at intervals of $t$ welve days. Mr. B. T. Galloway has shown that nursery stock can be sprayed with this solution five times, at a cost of eight cents per thousand trees, estimating the copper carbonate at forty cents per pound, and the ammonia $\left(26^{\circ}\right)$ at eight cents per pound.

Literature.-An excellent general account of this disease, by Mr. M. B. Waite, may be found in the 1.888 Report of the Department of Agriculture (pp. 352-357) ; while notices of remedial experiments appear in bulletins of the Division of Vegetable Pathology. 


\section{The Bitter Rot, Ripe Rot, or Apple Rot} Gloesporium fructigenum

The Bitter Rot of apples, frequently called the Ripe Rot, or simply the Apple Rot, is caused by a parasicic fungus which most commonly attacks the fruit as it approaches the ripening period, although it is said often to attack the apples at any time after they are threefourths of an inch in diameter. The injury is most likely first to appear at the calyx or blossom end of the fruit, but it may start anywhere upon the surface. It gradually spreads from the point of infection throughout the tissues, causing brown and decayed spots as

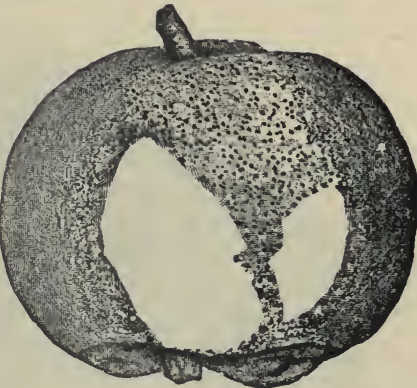

it progresses. The larger FIG. 16. APPLE AFFECTED BY BITfruits usually fall to the ground, but many of the TER ROT FUNGUS, SHOWING BLACK PUSTULES ON THE SKIN. smaller ones shrivel up and remain on the tree in a mummified condition. Great quantities of spores are developed on these withered "hangers-on," and by means of them the disease is started again the following spring. The fungus seems to be more destructive during damp weather. Professor H. Garman expresses the opinion that this disease causes greater loss in Kentucky than any other enemy of the orchardist. "It is no uncommon thing for three-fourths of all the fruit on a tree to be rendered worthless by its attacks. In the latter part of summer we find, in many orchards, the ground covered with well grown apples, suitable for marketing, as far as size and maturity are concerned, yet 
not worth gathering up because of the rot with which they are wholly or in part affected." Other southern states suffer equally serious losses. One orchard in Arkansas has been reported in which, in 1887, the attack of the fungus was so serere that seventy-five trees yielded less than twenty-five bushels of fruit. $\Lambda$ photographic view of one of the depressed rotten spots as it appears on the maturing fruit is shown in Fig. 1\%.

This disease is distinguished after it has become well established by the presence of small blackish pus-

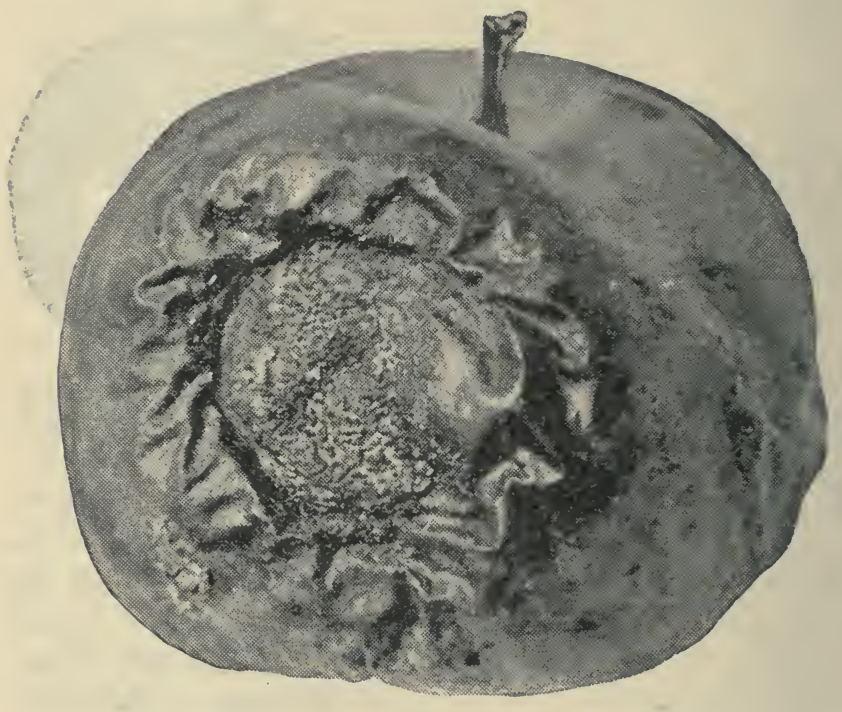

FIG. 17. APPIE SHOWING ROT SPOT.

tules scattered over the surface of the apple. These are the fruiting spots of the fungus. The mycelium which has penetrated the pulpy tissue of the fruit in all directions, disorganizing it and causing the rot, here develops a large number of cells, which rupture the skin of the apple and produce the spores at the tips of slender pro- 
jecting threads. These spores are blown off by the wind, or washed downward by rain. When one of them lodges upon another apple, where sufficient heat and moisture is present, it germinates by sending out a little tube, and may thus start the disease in a new situation.

If the mycelium of the fungus running through the apple is carefully examined, one will see at frequent intervals on the threads small spore-like bunches, simjlar to those shown in $B$, Fig. 19. From these other mycelium threads may start. In the same figure a ger-

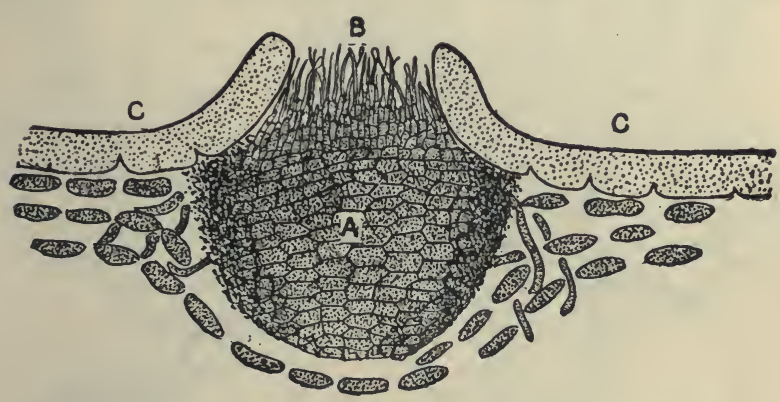

FIG. 18. SECTION OF PUSTULE.

$A$, Mass of fungus threads and cells; $B$, spore-bearing threads; $C C$, skin of apple ruptured by the fungus.

minating summer spore is seen in $C$, and one of the pustules already referred to in $A$.

This same fungus attacks grapes, and Dr. Halstead has recently found that it will develop upon pears, peaches, egg plants and peppers. Consequently it seems to have a wide range of hosts, and general clean culture is evidently important as a method of preventing its injuries.

Treatment.-The first step toward the successful prevention of this disease is the removal and burning of the mummied apples on the trees. This should be done during winter. It would be desirable, also, to rake up and burn, or bury, the fallen fruit and surrounding rub- 
bish. Then the Bordeaux mixture treatment recommended for the prevention of apple scab will have a decided influence in lessening the amount of damage.

An account of experiments with this disease may be found in Bulletin No. 44 of the Kentucky Agricultural Experiment Station; and of its nature in the 1889 report of the same station. It is also discussed in the 1887 Report of the U. S. Department of Agriculture, and more fully in the Journal of Mycology, v. VI, p. 164.

\section{The Apple Rust}

\section{Gymnosporangium and Roestelia}

A peculiarity of many parasitic fungi is that the complete cycle of their existence is not passed upon a single host-plant, but that, instead, one phase of derel-

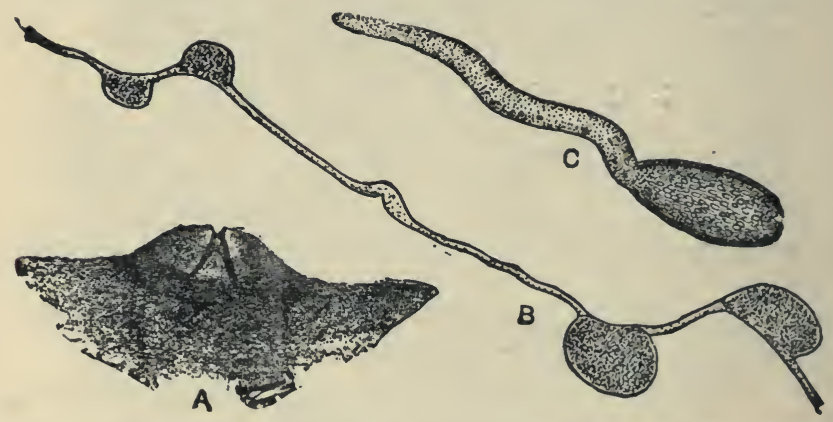

FIG. 19. $A$, surface view of pustule; $B$, mycelium thread; $C$, germinating spore. Magnified.

opment occurs upon one plant, while another quite aifferent stage of existence is passed on an entirely different host. A striking illustration of this is seen in the case of the rusts which sometimes affect apple trees, causing the leaves to become more or less blistered with orange-yellow spots. In this disease the fungus on the apple is an alternating form arising from spores produced by the socalled "cedar-apples," or "cedar-balls" of cedar or juni- 


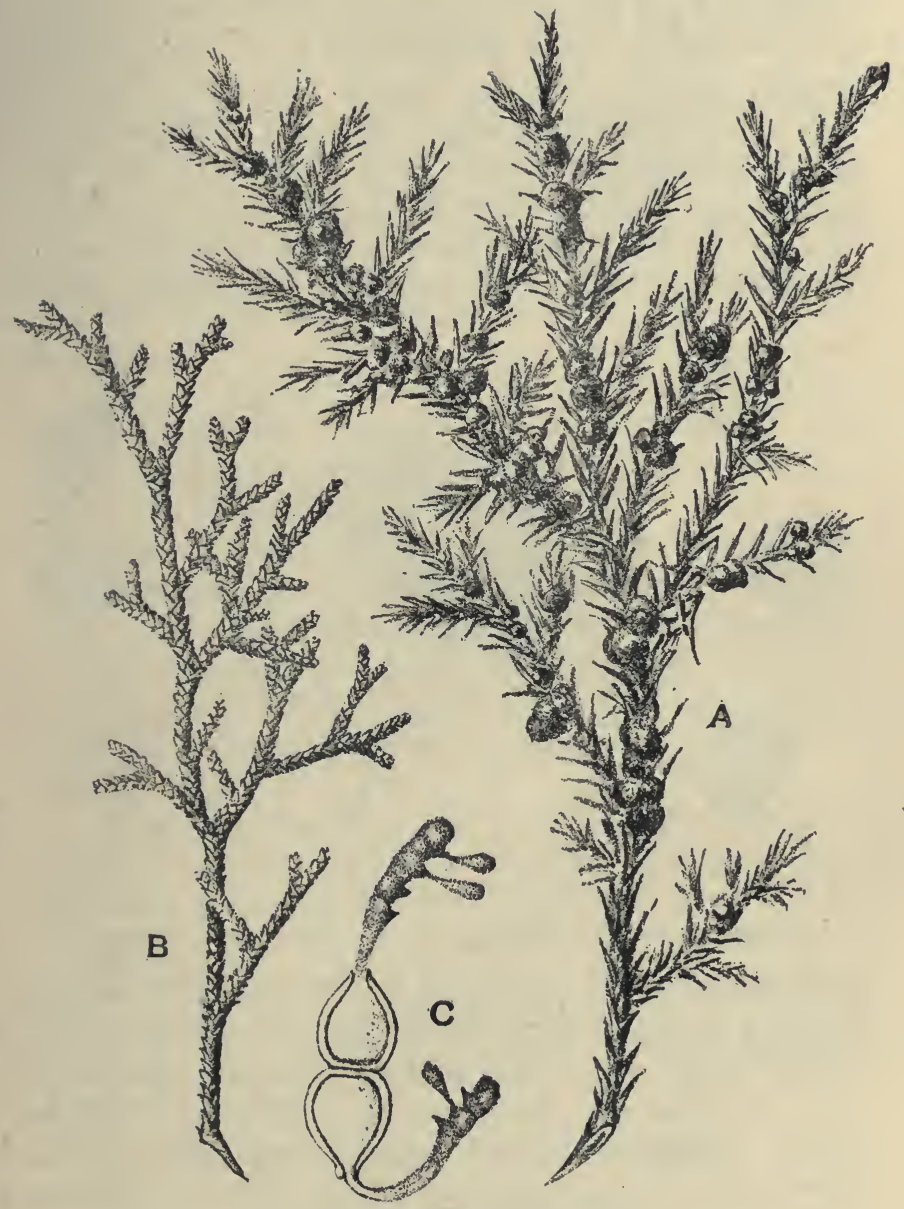

PLATE III. CEDAR APPLES (Fymnosporanguim clavipes). 
per. The presence of the fungus causes a peculiar development of the cedar leaves, as may be seen by reference to Plate III, where a normal healthy cedar branch is shown at $B$, and a diseased one at $A$. The affected branch not only has the "apples" developed, but the leaves are entirely changed in shape. Reproductive spores are produced from these "apples;" they germinate in a way illustrated at $C$, and are blown about by the wind. When one is carried to an apple leaf where conditions farorable to germination are present, it may
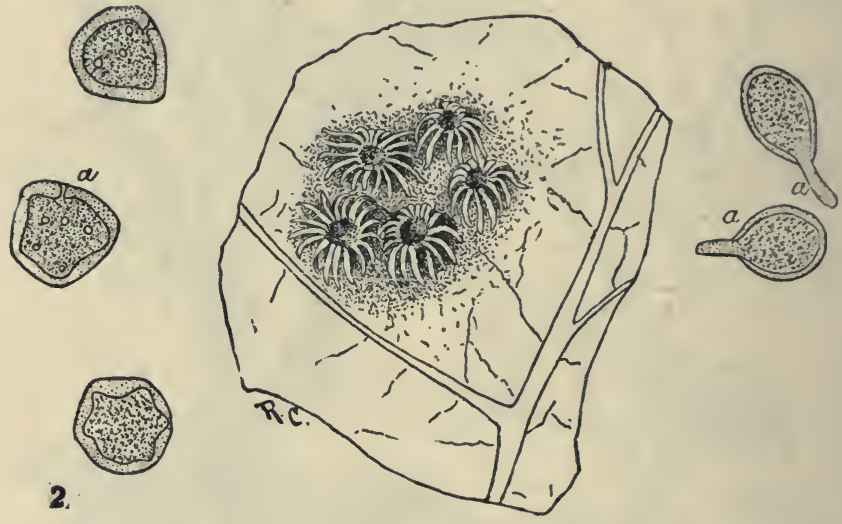

FiG. 20. APPLE RUST.

1, Cluster cups on under surface of leaf; 2, spores; 3, spores germinating.

develop and produce the apple rust. The affected apple leaf has scurfy bunches on the under surface, the area on the upper surface above these becoming orange-yellow, or sometimes almost crimson, in color. As the disease progresses the leaf becomes more and more distorted, and in case the injury affects a large proportion of the leaves serious damage to the tree may result.

The spores are produced in great numbers on the orange-yellow areas of the apple leaf, and are blown 
away by the wind. Those which light upon red cedar, under favorable conditions, may develop, and by so doing carry the disease back to the original host plant. Thus there is a continual alternation of the generations of the fungus.

The form of the fungus which occurs upon apples is commonly called the Roestelia form. Besides the discolored areas on the upper surface of the leaf, the peculiar "cluster-cups" of the fungus are developed on the under surface. A group of these is represented in Fig. 20. The "cups" are usually about a quarter of an inch in diameter. In them the chocolate brown spores are developed; some of these are seen in 2 , where the thin places in the wall through which the germinating tubes are to develop are seen at $a$, while in 3 some germinating spores are represented.

Treatment.-The knowledge of the fact that one essential stage of the fungus is passed upon red cedar, leads to the suggestion that, in a given region, the injury to apples may be prevented by destroying the red cedars. It is probable that spraying orchards with fungicides for scab, or other diseases, will also assist in preventing the rust.

Literature.-Dr. B. D. Halstead has published an excellent general discussion of the relations of apple rusts and cedar apples, in the 1888 Report of the Department of Agriculture (pp. 370-381). Professor A. B. Seymour has also treated of them in the Transactions of the American Horticultural Society (v. IV, p. 152), and Dr. R. Thaxter, in the 1891. Report of the Connecticut Experiment Station.

\section{The Apple Twig Blight}

\section{Micrococcus amylovorus}

The twigs of apple trees, together with the leaves, flowers or fruit which they bear, often turn brown or 

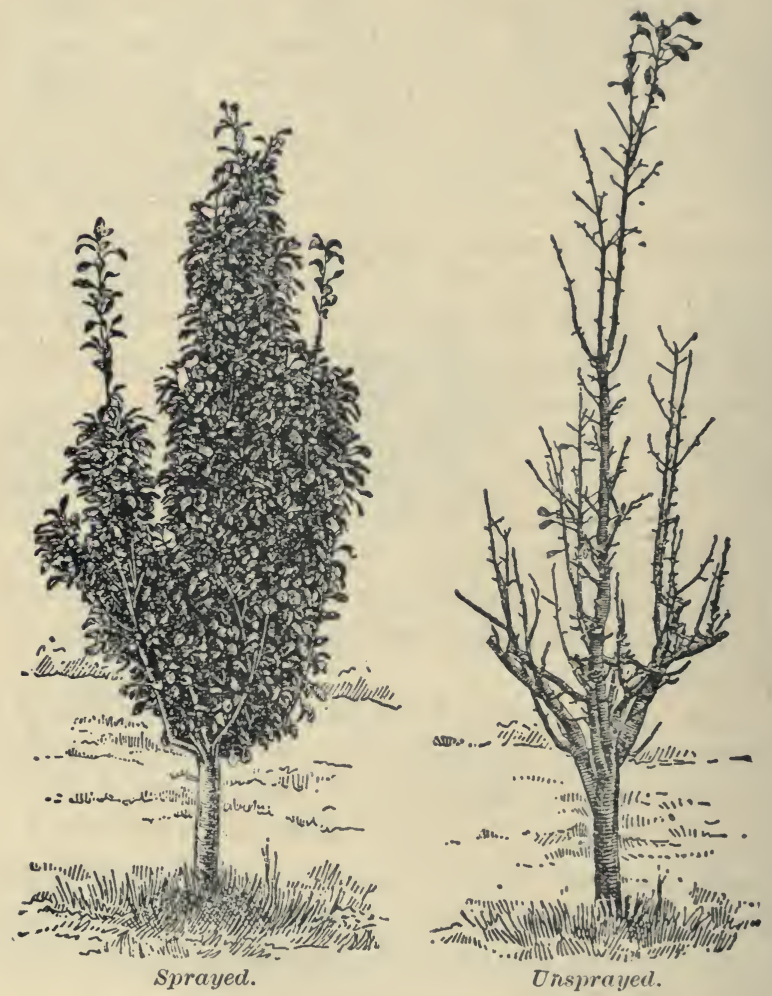

PLATE IV. PEAR LEAF-BLIGHT EXPEIIMNT. 
black, and die, in a manner similar to that of pear twigs affected by pear blight. Such injuries to apple are commonly called "twig blight," or "fire blight." They are, however, due to the same germs as the pear blight, discussed on a later page under the pear. Culting off and burning affected twigs is the best remedial measure.

\section{FUNGI AFFECTING THE PEAR}

\section{The Pear Leaf=blight}

\section{Entomosporium maculatum}

This is probably the most generally destructive fungous diseuse to which the pear is subject. It appears early in spring, soon after the leaves develop, usually

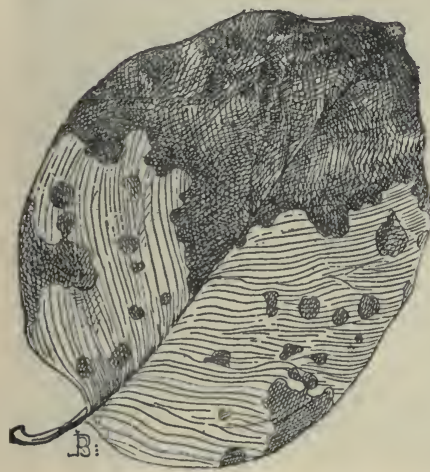

FIG. 21. QUINCE LEAF SHOWING LEAF•BLIGHT.

revealing its presence at first by minute, dull reddish spots on the upper surface of the leaf. A little later the spots appear on the lower surface also, and the reddish tint gives way to brown, with a darker center. As the fungus develops the spots enlarge, involving more and more of the tissues of the leaf, until the tissues directly affected within the spots, and those indirectly affected between, include nearly or quite the entire leaf, which appears sere and brown. Very young leaves sometimes curl up, as a result of the attack. The quince is also injurcd by this fungus, an infested leaf being represented in Fig. 21. When leaves are badly 


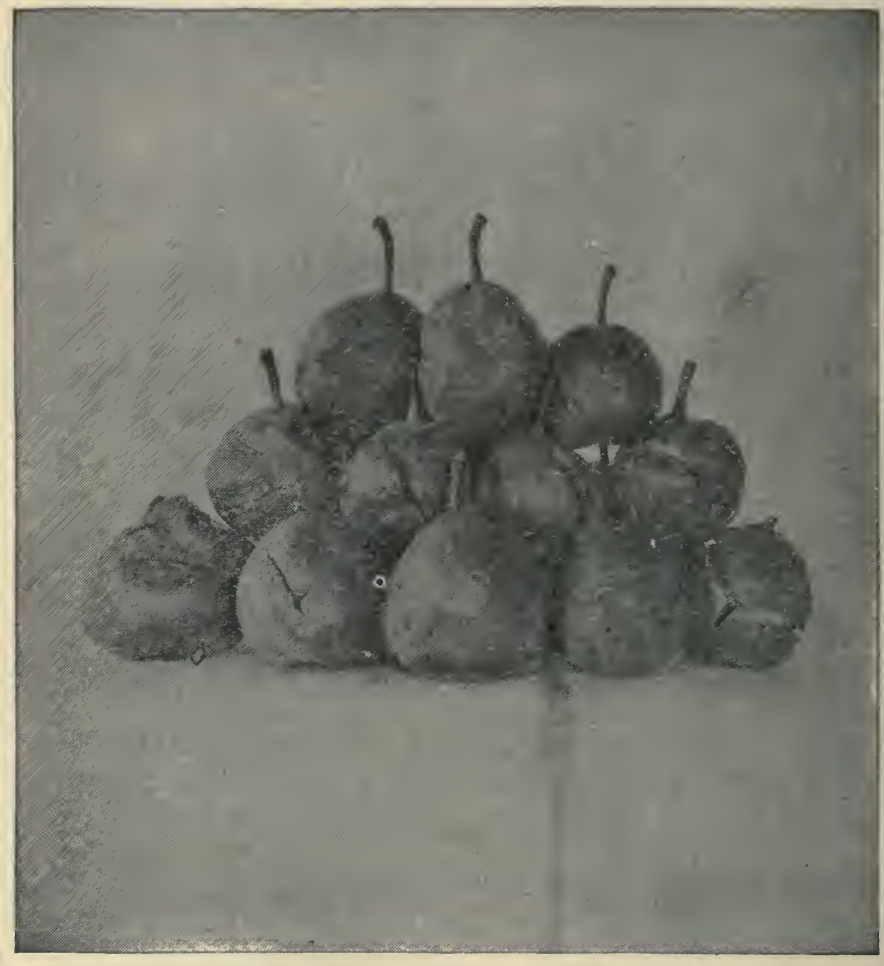

PLATE V. PEARS INJURED BY LEAF-BLIGHT FUNGUS. 
injured they fall off, and whole orchards are some times defoliated by the disease, the trees appearing as bare in midsummer as they normally do in winter (Plate IV, unsprayed). Of course, the effect upon the tree is very injurious; it is unable to store up the materials of growth properly, and it becomes weak and impoverished.

But this fungus does not confine its attention to the foliage ; the stems and fruit are also attacked. The former become blackish and dead, and the latter is at first covered with reddish pimples, which finally become blackened and roughened, and generally cause the pear to crack open in such a manner as to ruin the fruit. Several such pears, photographed by Dr. H. H. Lamson, are represented in Plate $\mathrm{V}$.

This disease is especially destructive to young pear trees in the nursery, and the defoliation caused by it quite generally prevents successful budding, unless preventive treatment is given. A good general account of the fungus occurs in the 1888 report of the Department of Agriculture.

The little black dots in the centers of the spots consist of the fruit of the fungus. If a vertical section be made of one of these and it be placed under the micro-

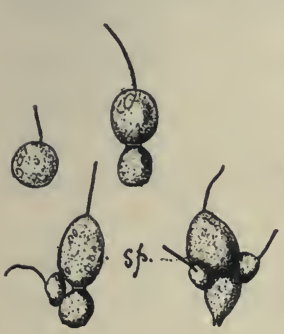

FIG. 22. PEAR LEAFBLIGHT SPORES. MAGNIFIED. scope, it will be seen that the peculiar two- to six-celled spores shown in Fig. 21 are borne upon short stalks coming from the mycelium in the leaf cells. These spores germinate under favorable conditions, sending out a tube which burrows its way into the tissues of the leaf, and starts the fungus again. These spores are the conidia, or summer spores. Other spores-the so-called winter sporesare said, by some botanists, to be found among the fallen leaves. 
Treatment.- Spray with the ammoniacal solution of carbonate of copper as soon as leaves begin to unfold, and repeat application two or three times at intervals of two weeks; or the dilute Bordeaux mixture may be used, spraying in the sane manner as recommended for apple scab. The effect of treatment with the Bordeaux mixture, as shown in one of Mr. Galloway's experiments, is illustrated in Plate IV. Discontinue the treatment before the fruit is half grown.

\section{The Pear Blight}

\section{Micrococcus amylovorus}

The literature of American horticulture during the present century contains frequent references to the perplexing malady called pear blight. Until recently there were innumerable theories as to the cause and cure of the disease; but now, thanks to the investigations of Professors Burrill and Arthur, we know that it is due to the presence of a specific germ-one of the bacteria-so minate as to require the aid of a powerful microscope to see it.

Pear blight is easily distinguished from other maladies. Limbs affected by it become dead and blackened, together with the leaves, flowers or fruit which they bear. The injury may be confined to one or a few limbs, or may gradually extend to the whole tree. The twigs of apples and certain other pomaceous fruits are also liable to the disease.

The germs of pear blight are so minute that they are carried through the air by the slightest wind. They seem to be unable to penetrate healthy bark, but gain access to the interior of the tree through the blossoms. They light upon the sticky surface of the inside of the flower cup, and are able to begin developing there, passing down through the stem to the twig below. The 
germs can also gain access through the tips of growing branches where the green growth is soft and succulent, and, no doubt, they occasionally enter through cracks in the bark.

After the bacteria have gained access to the tissues of the tree they multiply rapidly, and generally in the course of a few weeks have become so abundant as to show their presence by blackening the bark or blossoms. "As the disease progresses," says Professor Arthur, "the germs exude on the surface, and the gummy substance thus produced is washed off; the gum is dissolved and the germs set free and washed into the ground. The germs multiply there in rich mold and grow all winter, or year after year. In a dry time the wind takes up the germs into the air, or they may be taken up by simple evaporation. Now when the surface of the tissues is tender and moist, as in spring, the air, laden with these germs, playing over the trees, brings the germs in contact with the delicate tissues. The germs are held there by the moisture and enabled to grow; the disease gets a foothold, and in the course of a month or two it shows itself by the sudden blackening of the leaves." Insects also carry the germs to blossoms.

Treatment.-No successful method of preventing the disease by artificial applications to the trees has yet been found. But it has been shown that if the trees are carefully watched during the season of growth, and the affected twigs cut off (at least a foot below the lowest point of injury) and burned, the damage done may be greatly lessened. Professor Burrill advises the examination of the trees once a fortnight, and states that the bark reveals the damage best after a shower, when the surface is wet. It is important, also, to keep the bark free from wounds.

The fact that slow growing pear trees are less liable to injury by blight than those of rapid growth has long 
been noticed. Consequently, such cultural methods as will tend to produce a slow, steady growth are to be adopted.

Literature.-The really valuable publications concerning pear blight date from Professor Burrill's announcement of the genuine cause in 1880. His articles may be found in the following publications: Transactions Illinois State Horticultural Society, 1880, pp. 15\% 167 ; 1883, pp. 46-49; Report American Pomological Society; 1880 ; Report Trustees Illinois Industrial University, 1880 ; Transactions Illinois Department of Agriculture, 1880, pp. 433-436. Professor J. C. Arthur has also published a number of valuable papers. A summary of his results may be found in the Report U. S. Department of Agriculture, 1886,.pp. 125-129; Report of the American Pomological Society, 1885 ; and Report of the Michigan Horticultural Society, 1885, pp. 173-17\%. More recently Mr. M. B. Waite has been investigating the disease. His results may be looked for in the publications of the Division of Vegetable Pathology.

\section{The Pear Scab}

\section{Fusicladium pyrinum}

This disease is rery similar to apple scab, the fungus, in fact, being believed by many botanists to be the same species. At any rate, the chief points in the lifehistory and remedial treatment are the same as for the apple disease.

Care should be taken not to apply the Bordeaux mixture too late in the season. Early varieties should have but one spraying with this mixture after the fruit "sets," and late varieties but two. Where additional applications are needed, use the copper carbonate solution. 


\section{FUNGI AFFECTING THE QUINCE}

\section{The Leaf=blight and Fruit=spot}

\section{Entomosporium maculatum}

The leaves of quinces often become dotted with small round brown spots, resembling Fig. 23, which

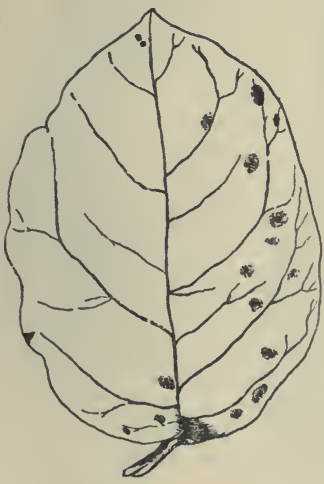
gradually become more numerous, and may finally run together to form large blotches, as shown in Fig. 21 (p. 41), involving, occasionally, the whole leaf, and causing the premature dropping of the foliage. This is the same fungus that causes the leaf-blight of the pear, and the main points in its development have already been described (pp. 41-44). Quince fruit, as well as foliage, is attacked by it, the effect on the FIG. 23. QUINCE LEAF-BLIGHT fruit being seen in small brown, or blackish spots which appear on the surface, and have given the disease the name of fruit-spot. Several of these spots frequently run together, and sometimes a large part of the surface becomes affected. The fungus dwarfs the fruit, and renders it less salable. The defoliation of the trees, of course, greatly reduces their vitality. Young quince trees in the nursery are especially liable to injury by this disease, as it causes the 
leaves to fall off during summer, and so prevents the growth necessary for successful grafting.

Treatment.-The treatment recommended for the pear (p. 44) is equally applicable to this fruit. The benefits of spraying with the Bordeaux mixture were

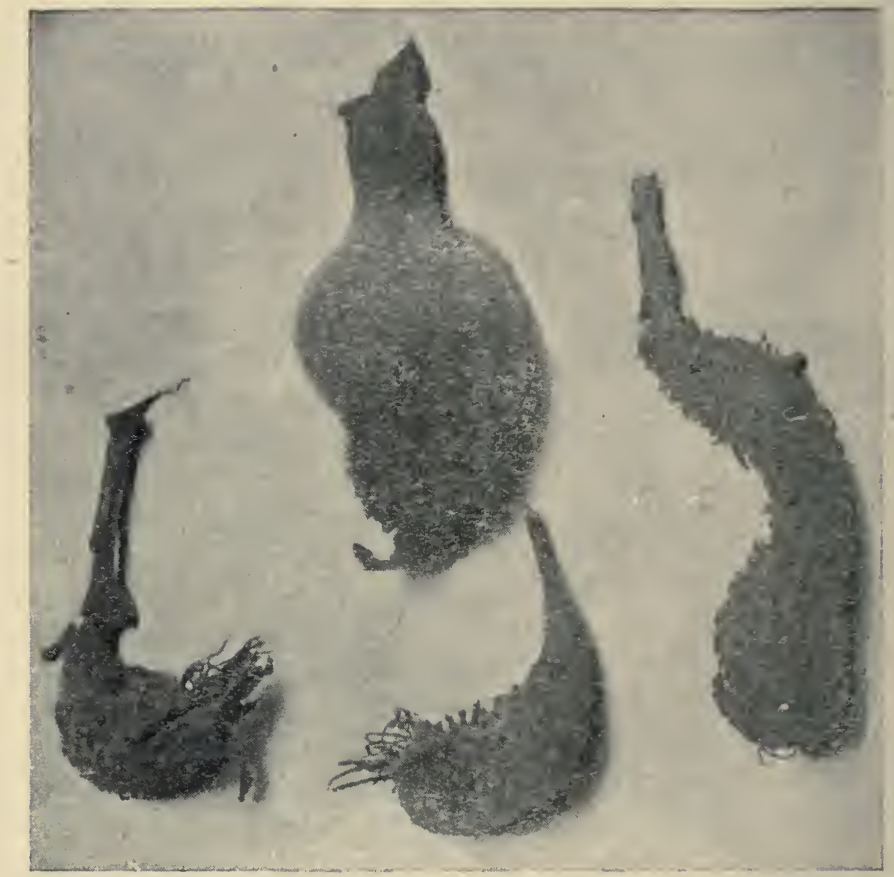

FIG. 24. YOUNG QUINCES INJURED BY RUST.

illustrated in a striking manner, by the results of some experiments made at the Connecticut Agricultural Experiment Station by Dr. Roland Thaxter. The sprayed rows had been treated both that season and the previous one, and so the year before had had an opportunity to store up 
nourishment for fruit production. Three applications were made, the first May 11, the second May 28, and the third June 22. Two sprayed rows yielded seventyone and one-half baskets of marketable fruit, while five untreated rows yielded one basket of marketable fruit. "Comparing the yield from the untreated rows, and estimating it at one-third basket per row, which is more than was actually obtained, the net income from a single treated row was one hundred times as great as from an untreated row."

\section{The Quince Rust}

\section{Roestelia aurantiaca}

Young quinces are sometimes disfigured by the presence of a rust fungus, in the peculiar way repre-

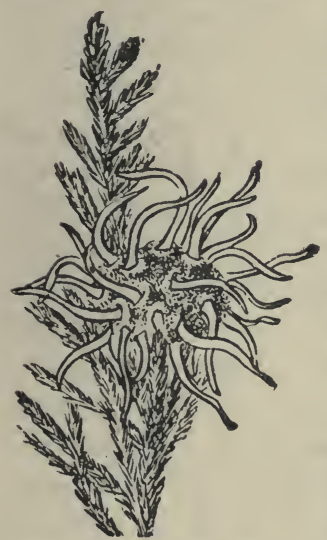
senter in Fig. 24. On some portion of the distorted surface orange spots eventually appear; they are usually more or less elevated. From them the spores of the fungus are produced in immense numbers, to be borue hither and thither by the wind. A peculiar fact concerning these spores is that they do not develop on the leares and fruit of other quinces, but, instead, are only able to develop upon the branches of red cedar and low juniper. Those spores which are FIG. 25. CEDAR BALL. blown to these plants under favorable conditions, produce on them the "cedar balls," or" "cedar apples," so often noticed. One of these is represented in Fig. 25. On the cedar or juniper other spores are produced, for the wind to carry back to quince to start the rust again. Thus there is constantly what is 
known as an alternation of the generations of the fungus, and two entirely different plants are required for its continued growth.

This rust is very similar to that which occurs upon the apple, discussed on a previous page. One important preventive measure consists in the destruction of cedars and junipers; and, probably, spraying with fungicides will prove to be another.

\section{The Black Rot}

\section{Sphoropsis malorum}

The fruit of the quince is subject to injury by several fungi which cause rot. The ripe rot of apples due to Glocosporium fiuctigenum often attacks them; is species of Phoma causes what has been called the "pale rot," and other fungi occasionally induce decay. The most destructive of these fruit diseases, however, is the black rot, which usually first appears upon the fruit when it is half grown, or larger, in the guise of a small brownish spot on the surface, generally at the blossom end. The spot increases in size rapidly, and blackish pimples soon appear; later the skin ruptures at these pimples, and the spores of the fungus escape, to be distributed by the wind. The infested fruit often becomes mummified, and may remain on the bushes over winter. This fungus also attacks apple and other pomaceous fruits. Quince orchards in the vicinity of apple or pear trees are liable to infestation from them, and vice versa.

While it is probable that the use of fungicides will prevent this disease, it usually appears so near the time of harvest that their application may not be adrisable. Diseases of this kind may be prevented, to a considerable extent, at least, by clean culture,- the destruction of the rotting or mummified fruits, by means of which the disease is propagated. This may often be supplemented 
to advantage by comparatively late spraying with the ammoniacal solution of copper carbonate.

An illustrated account of this and other quince fruit rots will be found in Bulletin 91 of the New Jersey Experiment Station.

\section{The Twig Blight}

\section{Micrococcus amylovorus}

Quinces are sometimes attacked by the "fire blight," or "blight" of the pear, discussed on Pages 44 to 46 . Branches so attacked turn black and are easily distinguished. Cutting and burning, as recommended for the pear, are the best remedial measures. 


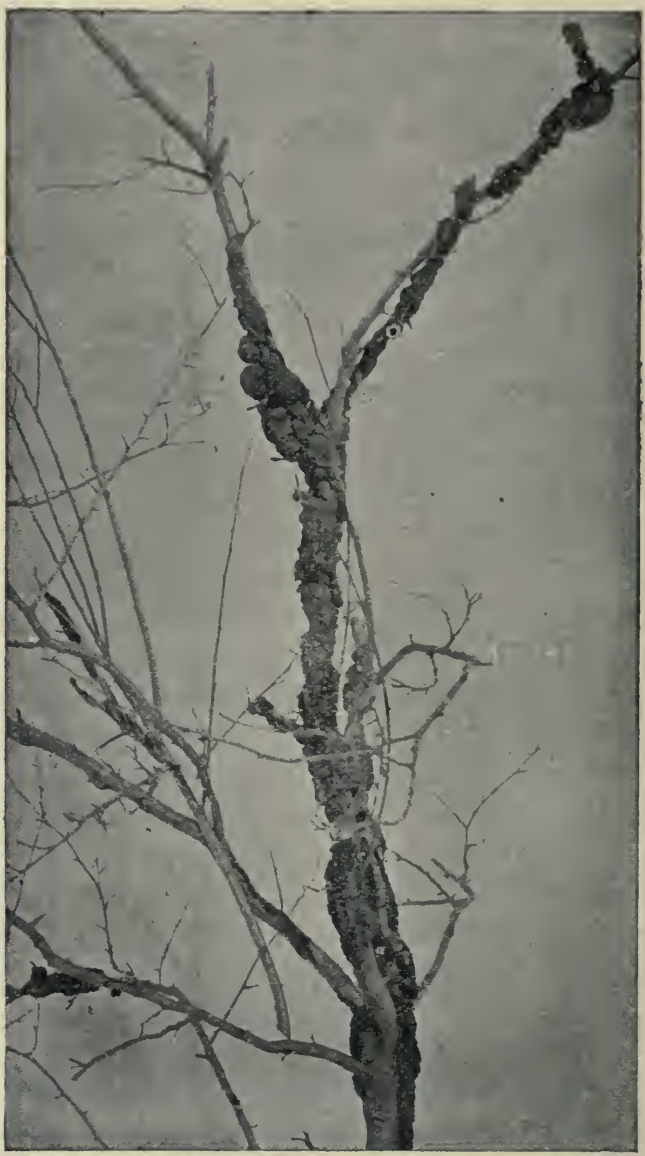

Plate VI. BRANCHES OF YOUNG PLUM TREE AFFECTED BY BLACK KNOT. 


\section{FUNGI AFFECTING THE PLUM}

\section{The Black Knot}

\section{Plowrightia morbosa}

No fungous disease of fruits is easier to recognize than this; the black, wart-like excrescences upon the twigs and branches of plum and cherry trees are too well known to the majority of fruit growers. In many of the older settled portions of the country the disease prevails to such an extent, that it has led to the practical abandonment of the culture of these fruits; and a similar condition is threatened in other localities unless preventive measures are vigorously applied. The fungus attacks nearly all varieties of wild and cultivated plums, and most varieties of cherries.

During the earlier years of the present century there was much discussion concerning the cause of black knot. Some horticulturists contended that it was due to insects; some that it was a constitutional affection of the trees; and some that it was due to fungi. The latter proved the correct supposition, the life-history of the fungus having been first worked out in $18 \% 5$ by Dr. W. G. Farlow. Like other fungi, this one reproduces by means of spores. The knots first appear as swollen places on the twigs; as the swelling increases the bark cracks open longitudinally, and the fungus produces quantities of spores within these cracks, making them appear as if covered with a velvety olive coating. These are the summer spores; they are blown through the air by wind, and washed from twig to twig by rain; those 
that lodge upon the tender bark of young shoots send out germinating tubes and start other knots.

"As the season advances," says Dr. Halsted, "the young knots and the fresh growth of older ones lose their olive, velvety appearance, turn a dark color, and

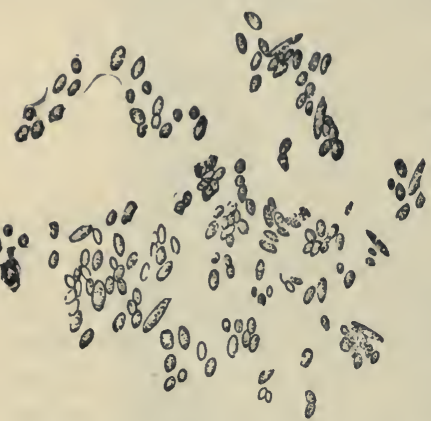

FIG. 26. SPORES OF BROWN ROT. MAGNIFIED. develop a hard incrustation on the surface. Within the substance of this black and brittle layer many spherical pits are formed, and, as winter advances, minute sacs are produced upon the wall of the cavity, that toward spring bear each eight oval bodies that are known as sac spores. These escape from their long sacs and pass out through a pore at the top of the cavity, and are then carried by the winds to the surface of a young cherry or plum twig, and thus begin another knot, which, in the course of time, produces a new crop of sum. mer, and another of winter spores, and thus the disease is preserved and propagated."

Treatment.-The only
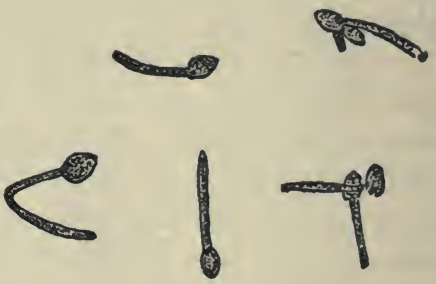

FIC. 27. BROWN ROT SPORES GERMINATLNG. MAGNIFIED.

successful treatment for a badly infested tree is to cut and burn it, trunk, branch and all. All knots on trees but little affected should be cut and burned. Never throw the removed knots on the ground, as spores are dereloped off as well as on the tree. When young knots appear on large limbs, or on limbs that one does 
not wish to remove, it is believed that painting them with a mixture of red oxide of iron in linseed oil will destroy them. Probably an application of the Bordeaux mixture would prove equally effective. All trees liable to injury by this disease should be examined at frequent intervals, and any signs of forming knots be at once removed.

Concerted action is necessary among all the fruit growers of a neighborhood, if the disease is to be stamped out. Local horticultural societies should agitate the matter and create a public opinion that will render it

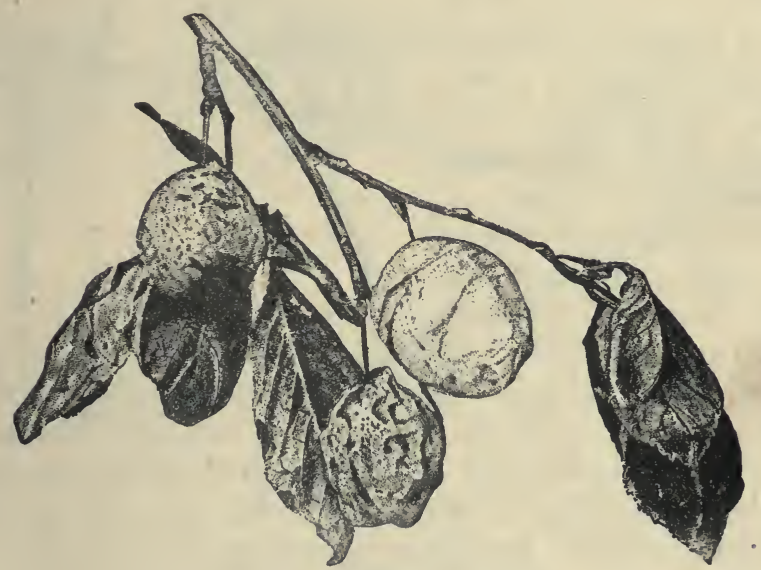

Fig. 28. PLUMS AFFECTED BY BRUWN ROT.

uncomfortable for any one to allow the knots to remain on his trees as a source of contamination for his neighbors' orchards. In some states laws have been enacted compelling the destruction of the knots. Wild cherry trees should be included in the examination for diseased trees.

Literature.-Dr. Farlow's article was published about 1875, in the Bulletin of the Bussy Institute. An 
excellent popular account of the disease, by Dr. Halsted, appears in Bulletin 78 of the New Jersey Experiment Station. 'There are many other short accounts scattered throngh our horticultural literature.

\section{The Brown Rot}

\section{Monilia fructigena}

The brown rot of stone fruits is probably familiar to every grower of plums, peaches or cherries in the older portions of the United

States. It is one of the most destructive fungous diseases of fruits, attacking not only the fruit itself, but also the twigs, leaves and blossoms. It is occasionally found upon the apple and pear, but in the Northern States is

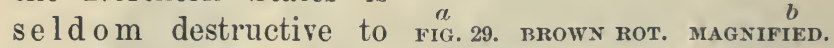
these fruits, although in $a$, Chains of spores; $b$, branching mycelium. some southern localities it is reported to do serious damage. The annual cycle of the fungus of brown rot may be briefly outlined as follows, starting with its attack upon the fruit: A minute spore (Fig. 26) falls upon a green plum on which there is a little water, left by rain or dew, and sends out a germinating tube which penetrates the skin of the fruit. Once inside it grows rapidly, pushing its branches through the pulp in all directions, and thus forming a dense mass of mycelium, which absorbs the contents of the cells, disorganizing the tissues and causing the so-called rot. The affected plum at first turns brown in one or two spots; these gradually enlarge until, finally, the whole plum becomes brown and "rotten." When it has reached this stage it 
soon becomes covered with a brownish, or ash-colored velvety coating, which consists of vast numbers of minute spores produced by the mycelium of the fungus. If one of these velvety masses be shaken over a glass "slide," and the slide be put under the microscope, it will be seen that a great many of the spores have separated and fallen off, as shown in Fig. 26. The spores are blown about by the wind, and when one of them lodges on an unaffected plum where sufficient moisture is

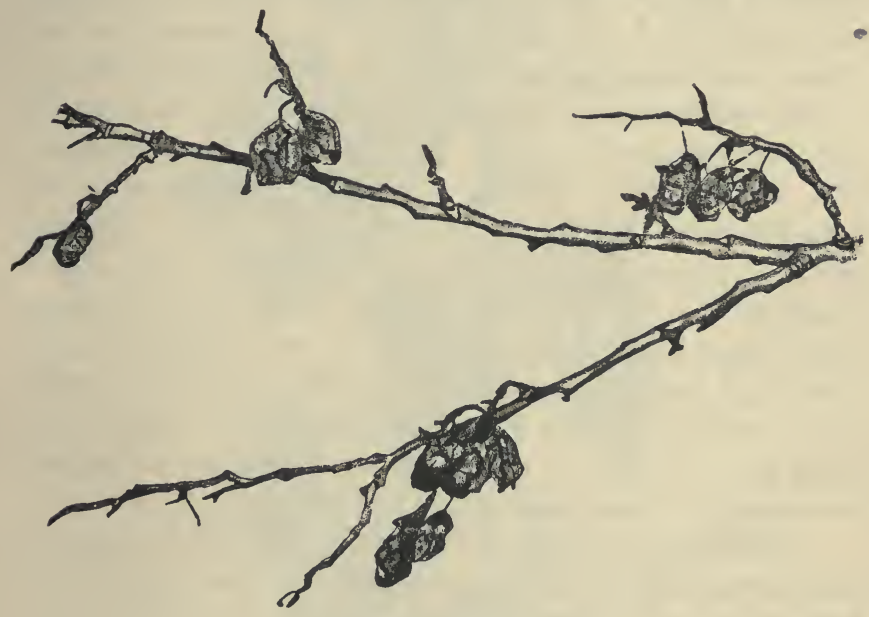

FIG. 30. MUMMIED PLUMS.

present it starts the disease again. The rotten plums continue hanging upon the tree, gradually shriveling up (Fig. 28), until finally they become dry and mummied husks, roughened by ridges of the skin, and in this state they remain on the trees through the winter (Fig. 30). On many of these mummied plums some spores will adhere, even until the following spring, when they apparently have the power of germinating; and in all, or nearly all, of them the mycelium remains in a dormant 
condition, so that during the warm, damp weather of early spring this inycelium is able to produce a new crop of spores. 'These spores are scattered everywhere, and many of them develop in the blossoms and young leares. Serious losses are sometimes occusioned by this kind of injury to the blossoms. As soon as the fruit is well formed it also may be attacked.

Treatment.- The first essential to success in preventing this disease is to pick off and burn, as early in winter as possible, all mummied plums hanging upon the trees; and the spraying treatment recommended below should also be supplemented by an oceasional inspection of the bearing trees, and the removal and burning of such rotting plums as may be seen. The most successful results so far obtained in spraying for this disease, have followed the use of the dilute Bordeaux mixture and the ammoniacal solution of carbonate of copper, especially the former. Spray first before the blossoms open; then as soon as the fruit is well formed spray again, and repeat the application twice later at intervals of two weeks. If the Bordeaux mixture is used, Paris green may be added for the earlier sprayings, to destroy the curculio at the same time.

Literature.-One of the first general accounts of this disease was published in 1885, by Professor J. C. Arthur, in the Fourth Report of the New York Agricultural Experiment Station. This was followed, in 1888 , by an extended article, illustrated by two excellent plates, by Mr. B. T. Galloway, in the Report of the United States Department of Agriculture for that year (p. 349-352); and since then Dr. Erwin F. Snith has contributed to the Journal of Mycology (v. V, p. 123; v. VII, p. 36) some valuable additional information. Professor J. E. Humphrey has also published a popular account of the disease in the Eighth Report of the Massachusetts Agricultural Experiment Station. 


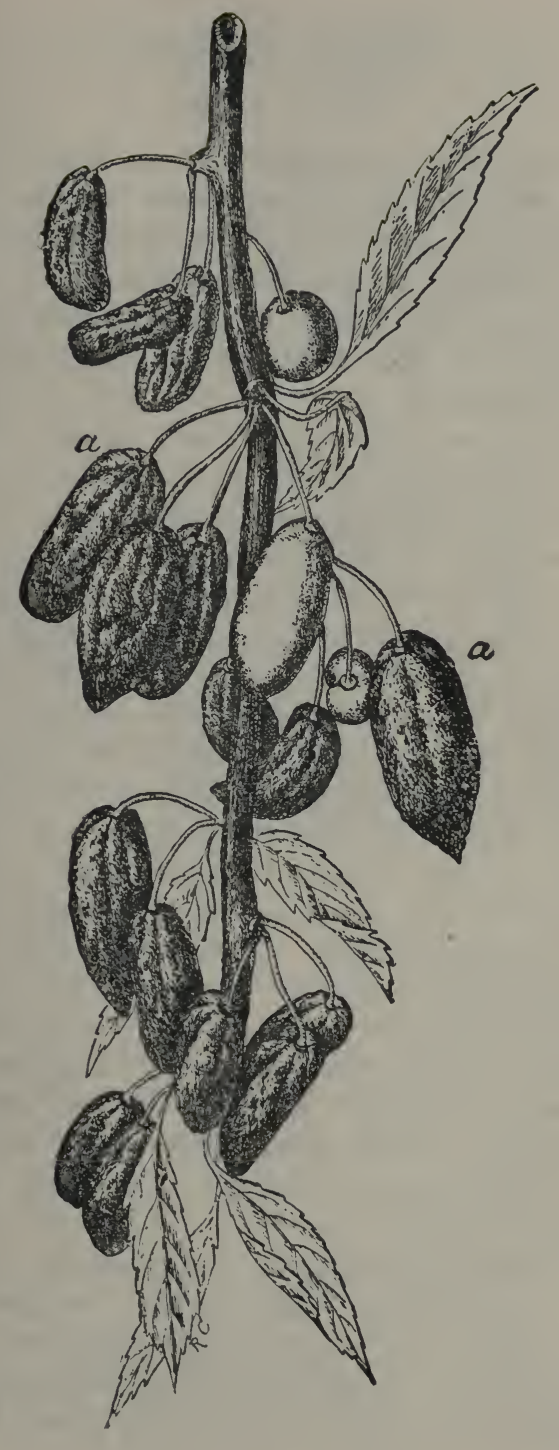

PLATE VI. PITM POCKETS. 


\section{Plum Pockets}

Taphrina pruni

Although this remarkable disease has been known for many years (having, indeed, been described as early as 1593), its real cause has been recognized only comparatively recently. It was formerly supposed to result from the attacks of insects, or from improper fertilization of the ovule; but it is now known to be due to the growth of a fungus.

Mr. Galloway states that " the 'pockets' (Plate VI) make their appearance soon after the flowers have fallen, attain full size and drop from the trees toward the middle or last of June. At first they are more or less globular in shape, but as they grow older they become oblong, or oval, and frequently more or less curved. 'They vary in size, but, as a rule, are from one to two inches in length, and from one-half to one inch in diameter. When young they are nearly smooth, and can be distinguished from the healthy fruit by their pale yellow or reddish color. As they grow older the color changes to gray, the surface appearing as though it had been sprinkled with fine powder, and at the same time the pockets become wrinkled. Finally they turn black, or dark brown, and rattle like bladders when brought in contact with any hard substance. They remain on the tree in this condition for two or three days, then fall to the ground and perish. Sections through the diseased fruit show that the walls are quite thick, and that in place of a stone there is a large cavity filled with fungous threads and air."

The leares and young branches are also sometimes attacked by the fungus; both become swollen and distorted. When a tree once begins to bear the pockets it usually continues bearing them during following seasons, unless vigorously pruned. The red and purple varieties 
are the ones most often attacked, but all kinds are liable to injury; and the fungus is occasionally found upon wild cherries.

The mycelium of this fungus consists of numerous colorless threads which ramify through the tissues of the young fruit. A special development of these threads occurs just beneath the outer skin (cuticle), and from this there are sent upward numbers of short cylindrical bodies (Fig. $31 a$ ), which finally burst through the skin and grow till quite long, as seen at $b$, being filled with a

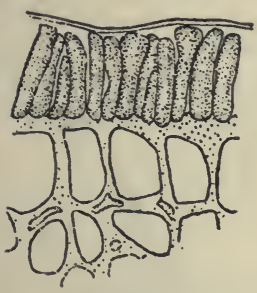

$a$

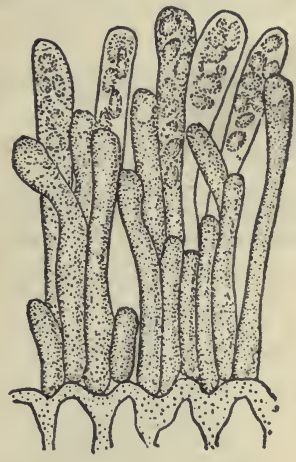

$b$
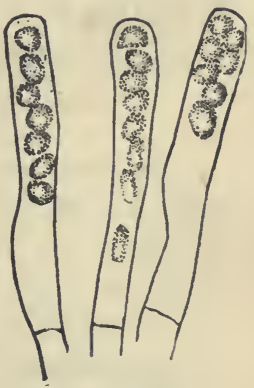

$c$

Fig. 31. PluM POCKRT FugGus. MAgNified.

granular matter. Then a transrerse partition is produced a short distance from the upper end, and the granular matter gathers itself together in six or eight little spores $(c)$. These spores finally escape from the cell in which they are held, and, under favorable conditions, germinate. In so doing each of the spores produces on one side a bud having a shape similar to the spore itself; this bud produces another bud, and this another, until the substance of the original spore is exhausted. But botanists have not yet been able to infect healthy plums with these spores or their buds. 
The mycelium of the fungus also winters over in the tips of the young branches.

Treatment. $-\Lambda$ vigorous pruning of all affected branches some distance from the tips, in order to remove the mycelium in the tissues, seems to be the most practicable remedial measure. The pockets should, of course, be removed before maturing, and the safest way will be to burn all the material so cut off.

Literature.- The best article upon this subject so far, published in America, occurs in the United States Department of Agriculture Report for 1888 (pp. $366-369)$.

\section{The Plum Fruit=scab}

Cladosporium carpophilum

In Iowa and some other localities a comparatively little known disease has recently been noticed on native
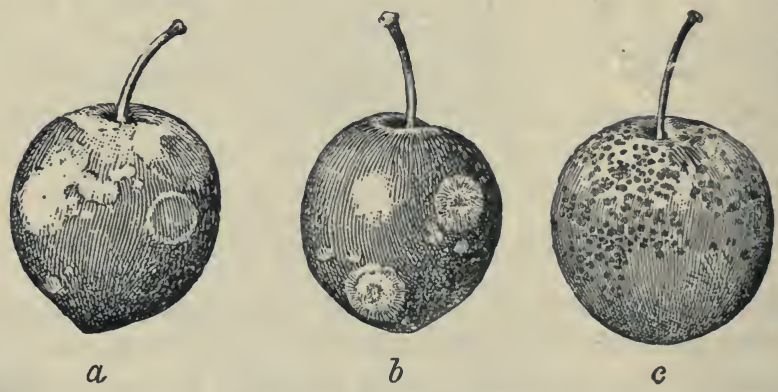

FIG. 32. PLUM DISEASES.

$a, b$, Fruit scab; $c$, fruit spot.

plums. It appears when the fruit is ripening, in the shape of minute round specks, of a paler or grayer color than the surrounding skin. These usually enlarge as the fruit ripens, finally attaining a diameter of a quarter, or even half an inch. Several spots sometimes run together to form a blotch. The mycelium of the fungus 
does not penetrate deeply into the fruit, and in itself the disease usually causes little direct damage ; but indirectly it is often injurious, by making cracks in the skin through which the spores of other fungi get entrance to the pulp of the fruit. Presumably spraying with Bordeaux mixture will have a preventive effect upon it.

\section{THE PLUM FRUIT-SPOT}

Professor L. H. Bailey has called attention to a fruit spot affecting certain native varieties of plums in the south (Fig. 32 c). It is caused by a species of Phoma, and is believed to be allied to the black rot of the grape, and to be controlled by the Bordeaux mixture.

\section{The Plum Leaf=blight}

\section{Cylindrosporium padi}

The leaves of plum and cherry trees are often attacked by a fungus which produces a blight that sometimes becomes very destructive, causing whole orchards to drop their foliage prematurely, and thus interfering with the normal development of the trees. Small discolored spots, generally of a purplish hue, are the first indications shown by the leaves, of the attack. In a short time these spots turn brown, the tissues being destroyed, and later the leaves become yellow, while many of the affected areas separate from the surrounding portion of the leaf and drop to the ground, leaving holes, which have given the disease the name of "shothole fungus." It is also called the leaf-spot disease. Under a lens the brown spots show a few black dots, where the reproductive spores are developing. The fungus is believed to live over winter on and in the fallen leaves.

Some confusion exists in horticultural and mycological literature concerning the nomenclature of this 
disease. Various names of fungi have been used in connection with it, one of the commonest being Seploria cerasina. The name printed above is the one now accepted by botanists.

The leaf-blight is especially destructive in the nursery, the young trees often being defoliated before the middle of August. Bearing plum trees also lose thoir leaves prematurely on account of it.

Treatment.-Experiments conducted on an extensive scale by the Ohio Experiment Station show that in the orchard this disease may be prevented by spraying with dilute Bordeaux mixture. Two or three sprayings early in the season are deemed sufficient. It should not be used too late, on account of the liability of the mixture to remain on the ripened fruit. In the nursery the Bordeaux mixture is also a preventive; the results of its use are well represented in Fig. 34, reduced from photographic

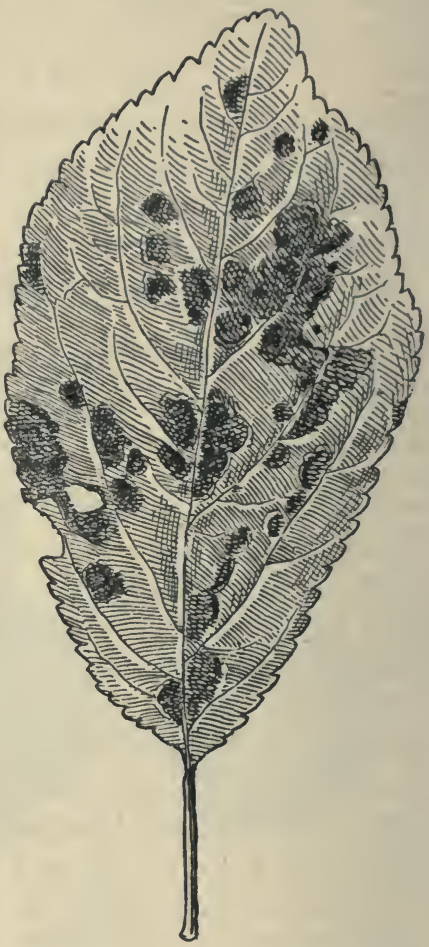

FIG. 33. DISEASED PLUM LEAF. views of experiments conducted by the Division of Vegetable Pathology.

Literature.-This disease has frequently been discussed in our horticultural literature, although very little of value concerning remedies has been published 
until quite recently. An account of the Ohio experiments mentioned above will be found in the Bulletin of the Ohio Experiment Station for December, 1891 (v. IV, pp. 216-217), and of the nursery experiments in the Journal of Mycology (v. VII, No. 3).
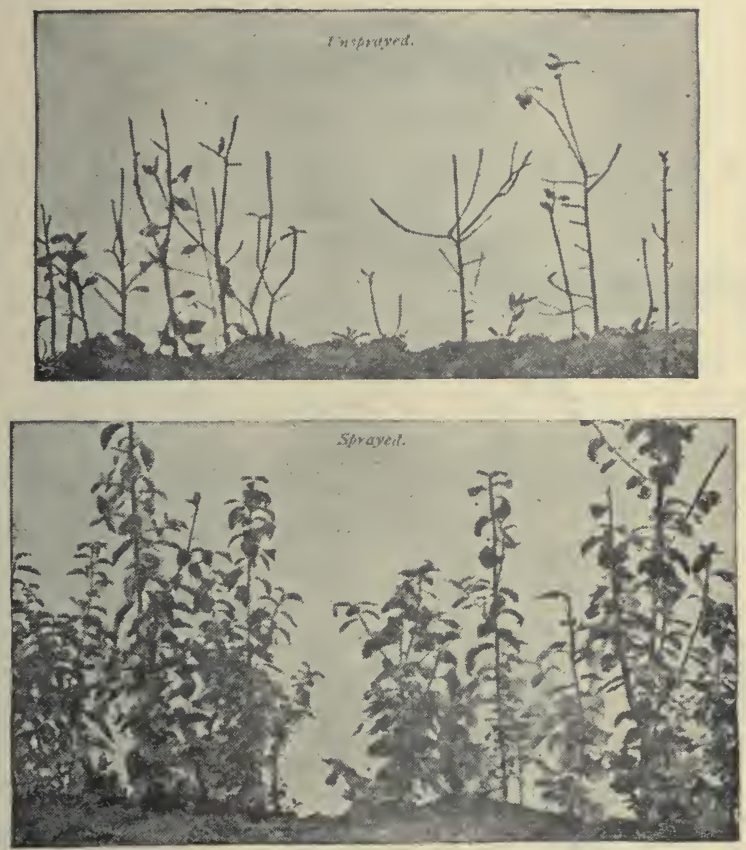

FIG. 34. SPRAYING FOR PLUM LEAF-BIIGH'T.

\section{The Plum Leaf=rust}

\section{Puccinia pruni-spinosas}

This is a disease somewhat similar to the 'last. Leaves affected by it become spotted with reddish above, and yellowish-brown below, and when the attack is severe the trees may be defoliated. The remedial treatment is the same as for the leaf-blight. 


\section{FUNGI AFFECTING THE CHERRY}

\section{The Brown Rot}

Monilia fructigena

As stated on page 56, where this disease is discussed

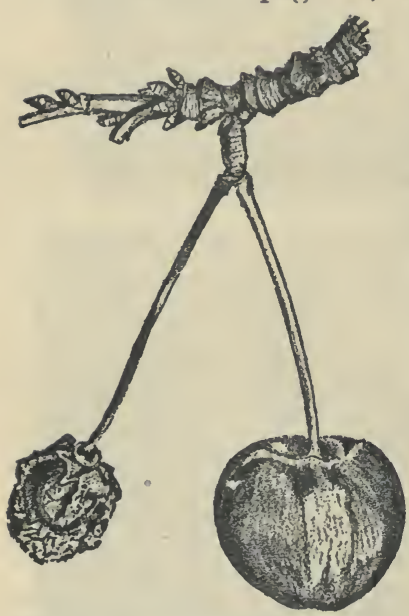
in its relations to the plum, it frequently attacks cherries, as well as plums and peaches. Its life-history on the cherry does not differ materially from that on the plum, although it usually does not pass from fruit to fruit so often on the cherry, because the individual fruits do not touch each other so much. Fig. 35 represents a sound ripe cherry, together with one mummitied by this disease.

FIG. 35. DISEASED AND SOUND CHERRY.

\section{The Black Knot}

Plowrightia morbosa

This disease is often as destructive to cherries as to plums, under which it has already been discussed (pp. 53-55). The account of its life-history and the means of exterminating it there given applies with equal force when it affects the present fruit.

The fungus which causes plum leaf-blight also attacks the cherry, and frequently does great injury. 


\section{FUNGI AFFECTING THE PEACH}

\section{The Peach Leaf=curl}

Taphrina deformans

It often happens that in spring, soon after the leaves begin to expand, the foliage of peach trees be-

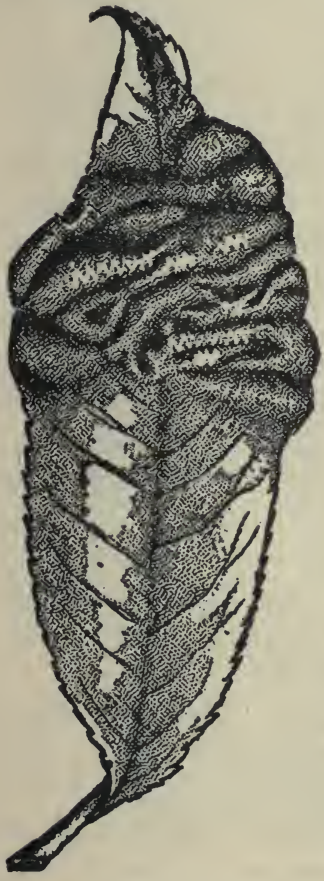
comes curled and misshapen. The leaves are usually thickened and discolored, and fall off in a short time. All the branches may be attacked, or the injury may be confined to only a part of the tree. When the disease is severe the young fruits fall off, and the crop for the year is destroyed. The defoliated trees soon push out a new set of leaves, but too late to repair the damage done to the fruit crop.

This, leaf-curl is most injurious during wet springs. It often ruins the peach crop over large areas. It is uncertain in its attacks, and comparatively little is known of the life-history of the fungus which causes it.

If a thin section of one of the swollen leaves be placed under a high power of the microscope, the FIG. 36. PEACH LEAF-CURL. threads of the mycelium of the fungus can be seen between the leaf cells, and sometimes extending through them. The mycelium is most abund- 
ant just beneath the outer skin, and it pushes out through the skin numerous "spore-sacs," each containing a half dozen or more spores. These spores are supposed to spread the disease to other peach leaves, but as stated above, very little is known of the life-history of this fungus.

Treatment.-No practical remedy for this disease has yet been found. The removal and burning of diseased leaves, whether on the tree or ground, is commonly . recommended; and spraying the trces early in spring, before the leaves expand, with some of the fungicides, has been suggested. The latter method is worthy of trial.

Literature.-The peach leaf-curl is very frequently mentioned in our horticultural literature, but fer important articles concerning it have been published. 'The best popular discussion that has come to my notice is in Professor Lamson-Scribner's excellent little volume on the "Fungus Diseases of the Grape and Other Plants" (pp. 126-131).

\section{The Peach Yellows}

The peculiar affection of peach trees called the "yellows," has been known to occur in America for at least a century, and during that time it has ravaged many of the fairest orchards of the country. Although most commonly affecting peaches, it also occurs in nectarines, almonds and apricots.

No disease of fruits has proved so difficult to investigate as this. Until very recently there were numberless theories as to its cause, but the investigations of Dr. Erwin F. Smith, to whom we are indebted for much of the positive knowledge now possessed concerning it, indicate that it is a germ disease, due, probably, to some obscure bacterium-like organism. 


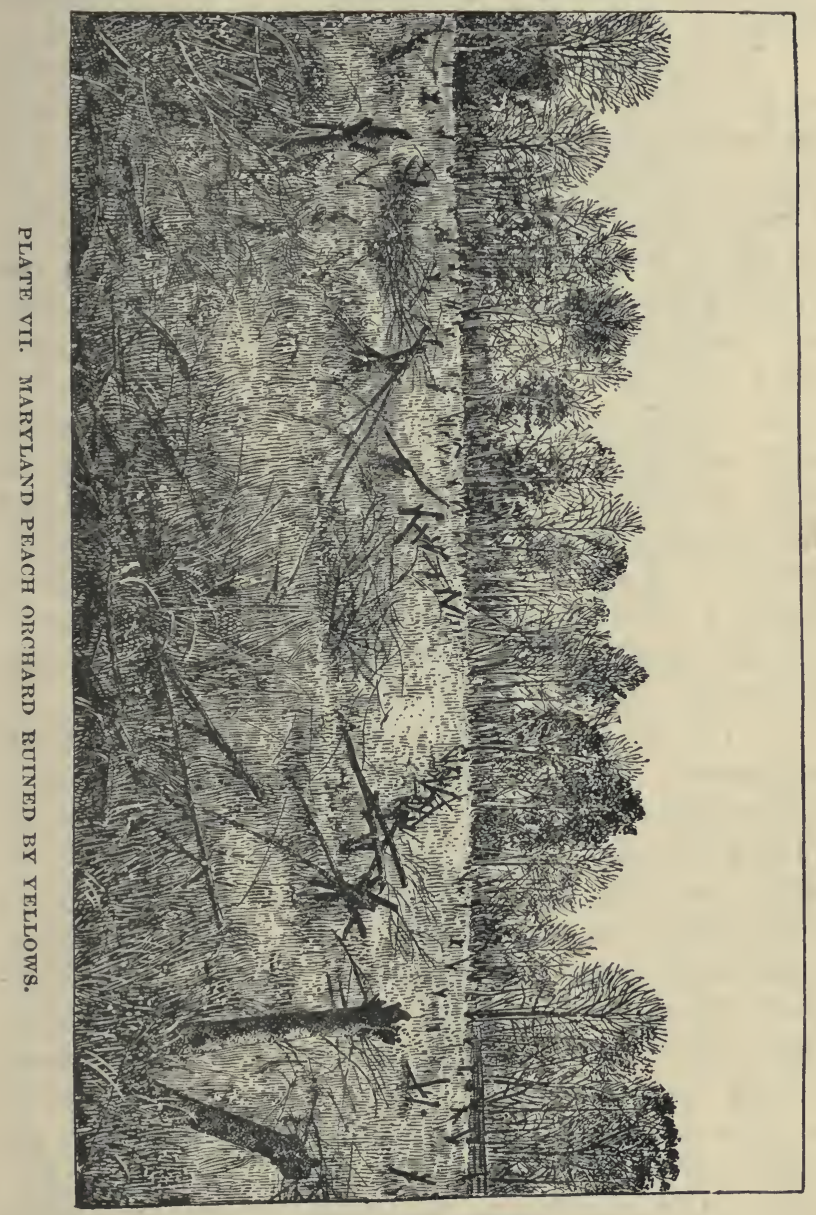


Peach yellows now occurs over a large portion of the States east of the Mississippi River. During recent years it has destroyed thousands of trees in Michigan, Maryland, Delaware, New Jersey and New York.

Symptoms.-According to Dr. Smith, "the eariiest unmistakable symptom of the yellows is the premature ripening of the fruit. Diseased trees ripen their fruit, in whole or in part, from a few days to several weeks in advance of the proper time. Often the peaches on one or two limbs only will be diseased, all the rest ripening in a normal manner. In such cases the premature peaches are full-grown, ripe, and high colored, when those on the rest of the tree are green and but half grown. These peaches, no matter what their natural color, are more or less red and purple spotted on the skin, and splashed and streaked within. Sometimes the normally white or yellow flesh is very beautifully mottled, or almost entirely crimson; again there is hardly a trace of the abnormal color. The flavor of immature peaches varies considerably, but they are usually insipid, and sometimes bitter.

"The next symptom, which generally appears the same season, but is sometimes delayed until the next, is the appearance of diseased, dwarfed growths upon the trunk and limbs. These growths bear diminutive leaves, which are pale green, yellowish, reddish or white. They often show a marked tendency to repeated branching, sometimes as many as four sets of branches being developed within a few months. These growths may arise either from obscure buds on the trunk and main limbs, or from the ordinary winter buds. They may appear at any time during the season, from spring until late autumn. Often the winter buds push in October or November, after the foliage has fallen, or even in August and September, while it is still green and vigorous.

"When attacked the tree is very often in a vigorous, healthy looking condition, and sometimes during the 
whole of the first season there is no sign of disease beyond the appearance of a few premature peaches, the foliage being fully grown and dark green, and the shoots in no way dwarfed or sickly. As already intimated, the

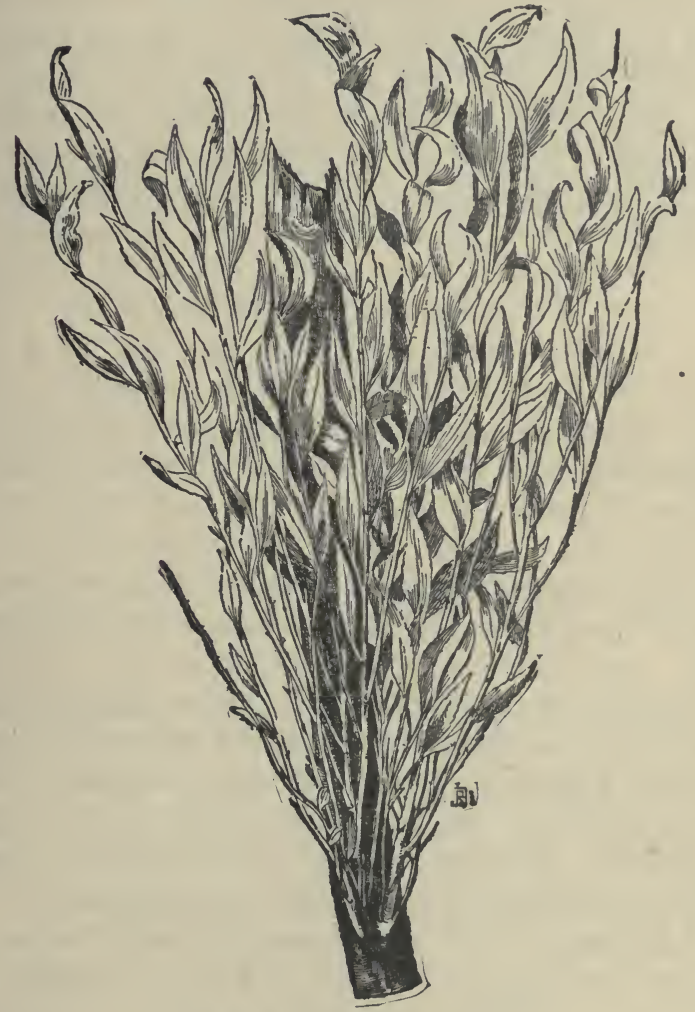

FIG. 37. YELLOWS TUFT.

disease usually appears first in one limb or one side of the tree, but sometimes in all parts of the tree at once, or on opposite sides. No matter to how slight an extent the tree is first diseased, it never recovers, but becomes 
entirely diseased in the course of two seasons, or at most, three.

"The limbs first attacked are badly diseased the seeond year, their entire growth, shoots and foliage, being mueh dwarfed and of a sickly green, tinged with yellow or reddish-brown. In eourse of two or three seasons the entire growth of the tree assumes this appearance, and is then a sufficient warrant for the common name, such trees espeeially, when massed in orchards, being distinguishable at some distance by their yellow or reddish-brown appearance, whieh is in marked contrast with the beautiful dark green of healthy foliage.

"Trees not infrequently die outright the seeond year of attaek, but ordinarily they languish for a number of years, dying gradually from the extremities downward. Often such trees are barren after the first year, or they may bear another crop of premature peaches, which are, however, of small size and very inferior flavor."

An orehard ruined by yellows is represented in Plate VII, while in Fig. $3 \%$ is shown a tuft of diseased twigs.

Treatment.-No remedy for this disease is known. The only sueeessful treatment yet found is that of promptly digging out and burning all affected trees. In several States this is made compulsory by special laws, and in Miehigan, at least, it has proven quite a satisfactory method of stamping out the disease.

Literature.-A very elaborate report upon the peach yellows, prepared by Dr. Erwin F. Smith, was published in 1888, as Bulletin No. 9 of the Botanieal Division of the United States Department of Agrieulture. A short summary of the same results was also published in the Department Report for the same year (pp. 393-398). Sinee then Dr. Smith has published various reports of progress in the publications of the 
Department and elsewhere, especially in Bulletin 1 of the Division of Vegetable Pathology.

\section{The Peach Rosette}

The name Peach Rosette has been given to an obscure disease affecting trees in various States, characterized by the presence of rosettes of leaves upon the branches. It has been studied by Dr. Smith in connection with peach yellows, and is treated of in the publications referred to above, especially in the Journal of Mycology (v. VI, No. 4).

\section{The Peach Rot}

\section{Monilia fmuctigena}

The main points in the development of this fungus have already been discussed under the plum (pp. 56-58). It also attacks peaches, and probably causes more loss on this fruit than on the other. Dr. E. F. Smith, who has made a special study of peach enemies, says: "This fungus is more common and far more destructive than any other observed on the peach in this country. It is rarely absent from the orchard, and in rainy weather it frequently destroys from one-half to three-fourths of the crop, in some cases the entire crop. Under its influence the fruit quickly loses its normal color and flavor, and becomes an entire loss to the grower. As the fungus invades the healthy tissues of the fruit the latter become leather-colored, or dark brown, and the peach is said to rot, although, as Von Thümen first pointed out, the change is not strictly a 'rot." "

During unusually wet springs the blossoms of peach trees are frequently destroyed by this fungus, and the young twigs are also attacked. The spores are propagated in vast numbers by the mummied peaches hanging on the trees, and are blown through the orchard, carry- 


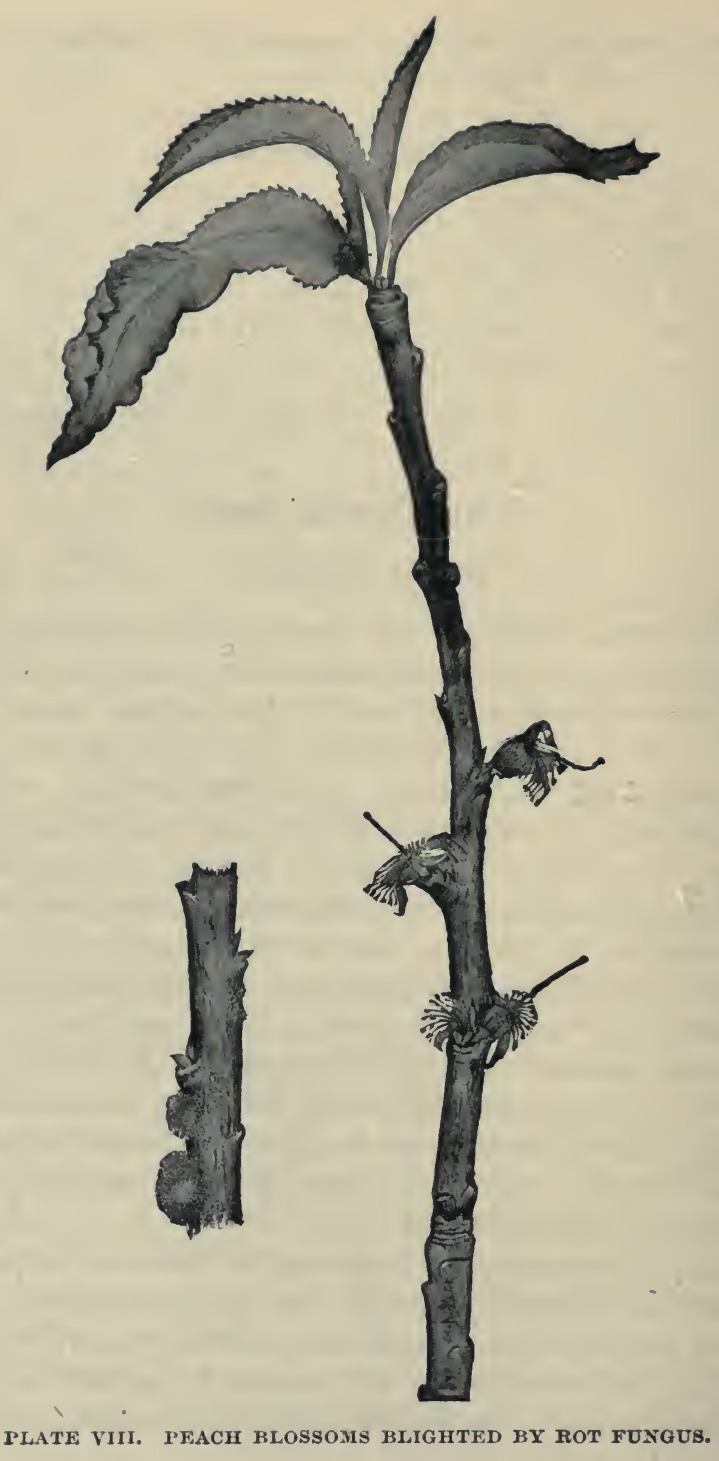


ing destruction wherever they light on a blossom. This injury is sometimes called "peach blight." Some blossoms so injured are represented at the right in Plate VIII, from a drawing published by Professor F. D. Chester. Some tufts of spores on a twig are shown at the left of the same figure.

Treatment.-The remarks upon this subject concerning the plum (p. 58) are equally applicable to the peach. Experiments made in Delaware indicate that a considerable proportion of the rot may be prevented by proper treatment. Professor Chester recommends the following procedure: Pick off late in autumn or early in winter all mummied fruit on the trees. It would be better to remove it at the time of picking, or soon after. Spray with simple solution copper sulphate (one pound to twenty-five gallons water) early in spring before fruit buds begin to swell. Spray again with ammoniacal solution copper carbonate as soon as these buds begin to swell, and repeat the application just before the buds open, to prevent injury to blossoms. "As soon as the fruit shall have reached full size and begins to show signs of color, make a third application. This should be followed by two or three other applications at close intervals of five or seven days during the ripening period. A heary rain followed by warm weather may, at this vital period, cause the peaches to rot rapidly; hence, due regard should be given this point in regulating the exact time when a spraying should be made. Due attention to this principle may save hundreds of baskets of fruit, and the grower can well afford to make spraying at the right time his first business." It may be doubted, however, whether these late applications are advisable, from a sanitary standpoint. Treatment with copper mixtures at frequent intervals during the ripening period means the presence of copper salt upon the marketed fruit, unless it is washed off after picking. 
Literature.-Dr. Smith's articles concerning the injuries of peaches caused by this fungus may be found in the Journal of Mycology, v. V, pp. 123-134, and subsequent issues. An account of Professor Chester's experiments is given in Bulletin XIX of the Delaware College Experiment Station.

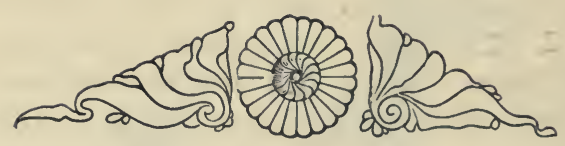




\section{PART II}

Fungi AFFECTING SMALL FRUITS 


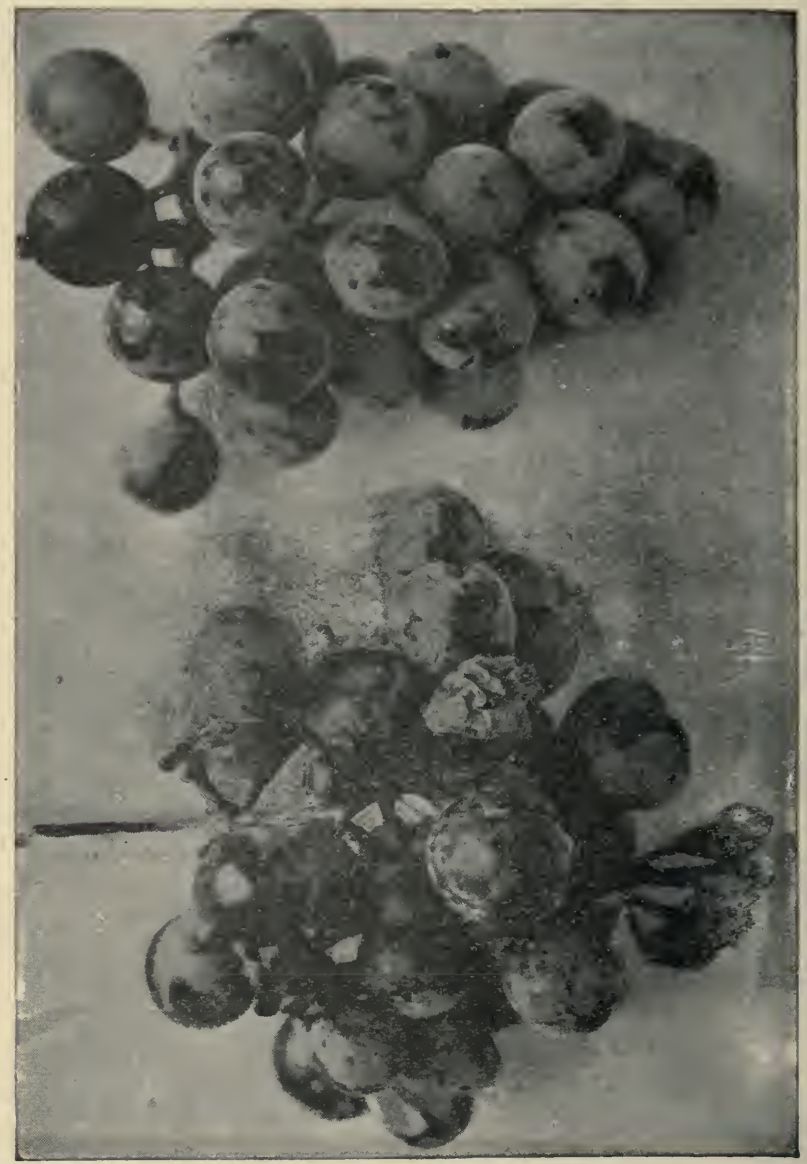

告 


\section{FUNGI AFFECTING THE GRAPE}

\section{The Black Rot}

\section{Loestadia bidwellii}

This is the most generally destructive fungous disease of the grape in the United States. It is most injurious in southern latitudes, being much less virulent as far north as Northern Ohio or Western New York than in Tennessee or the Carolinas. Like most fungous diseases, it develops with greatest rapidity during damp, hot weather, or when nights with heavy dews alteruate with hot days.

The black rot fungus usually first appears on the leaves early in summer in the shape of small, sharply defined reddish-brown spots, having yellowish centers, and dark brown or blackish borders, with numerous minute black pustules scattered over the surface. A short time afterward-generally about a fortnight-the attack upon the fruit becomes noticeable.

According to Professor F. D. Chester, who has studied this disease in Delaware, "the first appearance of rot upon the berry shows itself as a light brown spot, caused by the decay of the underlying pulp, this spot increasing in size so as to involve the entire berry. Simultaneous with this change, the parts first affected turn black and become covered with minute black pustules. Finally the entire berry dries and shrivels, the skin crumpling into angular folds. The entire berry is, at this stage, profusely and uniformly covered with the pustules. If a thin section be made through a rotting berry, the microscope will reveal the presence of minute 
threads growing into and between the cells. These threads which form the vegetating portion of the fungus, technically mycelium, are in diameter only about one-sixth that of a single fiber of cotton wool. It is the growth of these threads throngh the tissues of the berry which causes the decay and shriveling, externally manifest as black rot.

Microscopic Characters.-At points beneath the cuticle the mycelium collects into little knots, which afterwards develop into the black pustules seen upon

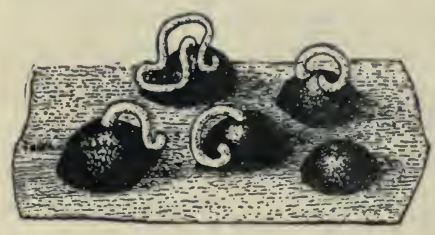

FIG. 38. BIT OF SKIN SHOWING PUS-

TULES, WITH FSCAPING COILED stylospores commonly esMASSES OF SPORES. MAGNIFIED. cape through an aperture or pore in the summit of the pycnidium in the form of threads; these threads are masses of spores glued together by some adherent substance. Fig. 38 represents a small bit of the cuticle or skin of the grape, with the pustules considerably magnified; through the pore in the summit of four of them the coiled masses of spores are escaping."

These stylospores are scattered through the vineyard, and those which lodge upon green grapes with a drop of moisture present, germinate by sending out a little tube, which penetrates the skin and starts the disease anew.

Besides these stylospores, there are three other kinds of spores produced by the black rot fungus. They are called by botanists the spermatia, the conidia, and the ascospores. The latter are produced in May and June, by the mycelium in the berries destroyed the pre- 
vious year, and so are supposed to start the disease for the season. Full accounts of the development of these various spores will be found in the articles reforred to below, under the head of Literature.

Treatment.-Spray with the ammoniacal solution of copper carbonate or the Bordeaux mixture five to eight times, making the first application when the buds begin to swell, early in May in the Northern States, and repeating at intervals of fifteen days. In case Bordeaux

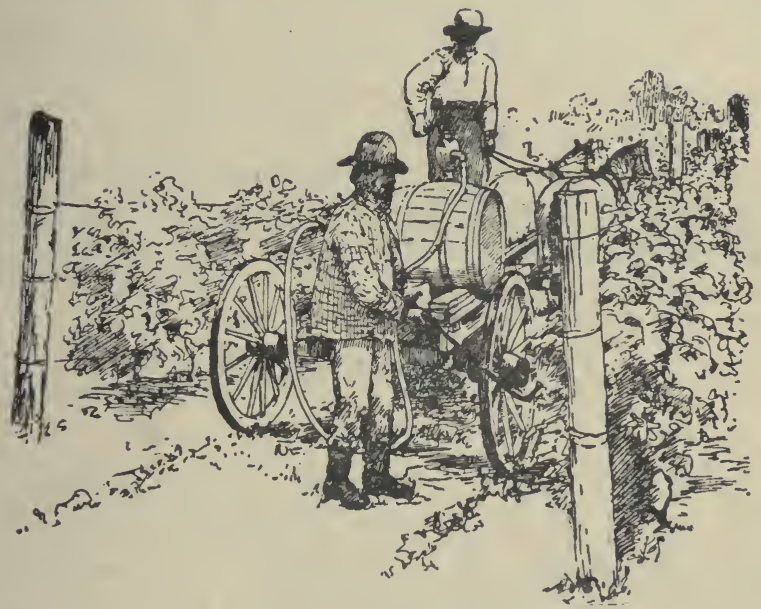

FIG. 39. OUTFIT FOIR SPRAYING GRAPES.

mixture is used, substitute the ammoniacal solution for the last one or two sprayings, to avoid spotting the fruit. The time of the first application will, of course, vary with the latitude,-earlier in the South than at the North. A convenient spraying outfit for vineyard use is illustrated in Fig. 39. It consists of a barrel with pump attached, mounted crosswise in a wagon. One man drives and pumps, and another sprays the vines behind the wagon. The hose terminates in an S-shaped 
pipe, by means of which the operator can spray any part of the vines. The great increase in value of sprayed over unsprayed grapes has been repeatedly demonstrated. It has been found that spraying with Bordeaux mixture not only prevents the disease, but keeps the vines in a much healthier and more thrifty condition than unsprayed vines not diseased.

Literature.-The black rot fungus has been very frequently diseussed in recent horticultural literature, especially by Messis. Scribner, Galloway, Chester and others. The principal articles are to be found as follows: United States Department of Agriculture, Reports, 1886, pp. 109-112 ; 188\%, pp. 326-327 ; 1888, pp. 326-334; 1889, pp, 399-405 ; 1890, pp. 394-396, and in various bulletins; Delaware Experiment Station, Bulletins Nos. VI and $\mathrm{X}$; Proceedings Society Promotion of Agricultural Science, 1888, pp. 68-73; 1889, pp. $62-64 ; 1890$, pp. 58-63.

\section{The Downy Mildew}

\section{Peronospora viticola}

In the Northern States the downy mildew, or brown rot, is one of the most destructive fungus enemies of the grape. It is distributed over nearly the entire eastern half of the United States, and occurs both upon the wild and cultivated varieties of grapes. It probably lived upon the former before the introduction of the latter. It appears usually about the time the vines blossom, producing upon the leaves a distinct whitish mildew which has earned for it its common name. The leaves, and often the young shoots, are more or less injured, and from them the fungus spreads to the newly formed berries, coating them also with mildew and causing them to fall off. The damage continues throughout the summer. When larger grape berries 
are attacked their growth is checked, and they gradually turn grayish or brown.

A good example of the parasitic fungi affecting higher plants is furnished by this downy mildew of the grape. It is a minute, parasitic plant that derelops at the expense of the tissues of the grape, thus causing blighting of the leaf and decay of the fruit. It attacks all the green parts of the vine, including the young shoots, as well as the leaves and berries, and, like other fungi, reproduces by means of spores.

When one of these spores falls upon a leaf where there is sufficient condensed moisture, its contents divide into a number of distinct particles, which escape through an opening in the spore-wall. Each of these particles mores about in the drop of water on the leaf for a few minutes,

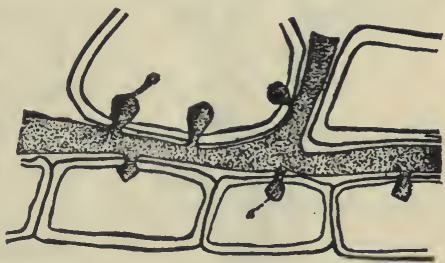
then comes to a standstill Fig. 40. SECTION of LEAF SHOWING and germinates by sending MYCELIUM OF FUNGUS. MAGNIFIED. out a little tube-somewhat as a kernel of corn in moist soil sends out its germinating radicle-and this tube penetrates the epidermis, or skin of the leaf. Once inside, the tube continues to grow, pushing about between the cells of the leaf, and forming the mycelium, or regetative portion of the fungus, which may be likened to the roots of the higher plants. As there is little nourishment to be obtained between the cells, this mycelium develops minute processes, which push through the cell walls and absorb the cell contents. A small section of an affected leaf, greatly magnified, is represented in Fig. 40, the unshaded double-walled spaces representing the leaf cells, the shaded part between the walls the mycelium of the fungus, and the projections marked $a$, $a$, the processes, or suckers, that penetrate the cells. 
After this mycelium has developed in the leaf for some time, it is ready to produce its spores. Consequently it sends out through the breathing pores, or stomata of the leaf, its fruiting branches. These bear

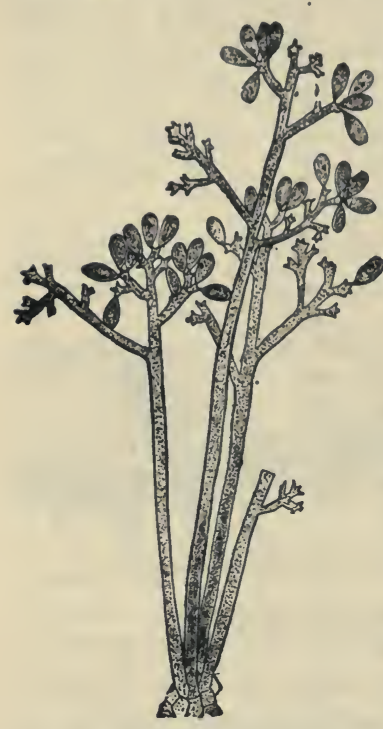

FIG. 41. FRUITING BRANCHES, GREATLY MAGNIFIED.

upon their tips small oval bodies, which are the spores. Some of these fruiting branches are shown in Fig. 41. The "mildew" visible to the naked eye is composed of these fruiting branches and their spores. It only develops under certain atmospheric conditions; so that the mycelium may exist in the affected parts of the vine for some time before this outward manifestation of its presence occurs. Besides the spores above described, which are produced during the summer season, and, consequently, are called summer spores, there is dereloped in autumn a different class of spores, by which the fungus passes through the winter. Hence, these latter are called the winter spores.

Treatment.-Eau Celeste is a practical and efficient preventive of this disease. Spray first a week or ten days before the vines blossom; second, as soon as the berries are well set; and third, about three weeks later. In very wet seasons it may be desirable to spray a fourth time, but this is seldom done. The other copper fungicides, especially the Bordeaux mixture, would doubtless prove equally effective, but eau celeste has been most generally used against this fungus, at least in some of the more important grape-growing regions of the country. 
Literature.-An excellent account of this downy mildew, by Professor F. L. Scribner, may be found in the United States Department of Agriculture, Report for 1886 (pp. 96-105). Since then much has been published, in the Department reports and bulletins, in experiment station bulletins, and in the horticultural press, concerning remedial measures.

\section{The Powdery Mildew}

\section{Uncinula ampelopsidis}

The powdery mildew of the grape seldom becomes seriously destructive, except in the Southern States and along the Pacific coast. It only thrives in very dry weather, and attacks all the green parts of the vine.

This fungus is closely related to the powdery mildews affecting apple and gooseberry, which are discussed on other pages of this book. During summer reproduction takes place by means of summer spores, which germinate upon the moist surface of leaf or fruit, the germinating tubes sending out suckers (Fig. $42 \mathrm{c}$ ) which penetrate the tissues of the host, and enable the mycelium to develop on the outside of the cuticle or skin. In this way the mycelium may grow all over the outer surface of the leaf, giving it a cobwebby appearance, and drawing nourishment from it by means of the suckers already mentioned. After it has grown for awhile in this way it sends up certain vertical branches $(b)$, which soon develop transverse partitions, and thus produce the small oval summer spores. These are light and easily distributed by the wind, and serve for the rapid extension and propagation of the fungus during summer.

Later in the season the mycelium produces another kind of spores-the so-called winter spores. These are more complicated in structure than their summer representatives; as seen under the microscope, they consist 
externally of a small spherical case, from which project fifteen or twenty, or sometimes more, rather long delicate appendages with recurved tips, as seen in $a$, Fig. 42. This is the outer spore-case (which botanists call the perithecium). If it be crushed it will break open on one side, and there will be pushed out about half a dozen small, oval, flattened bodies-the inner spore cases, or asci-within which may be seen from four to

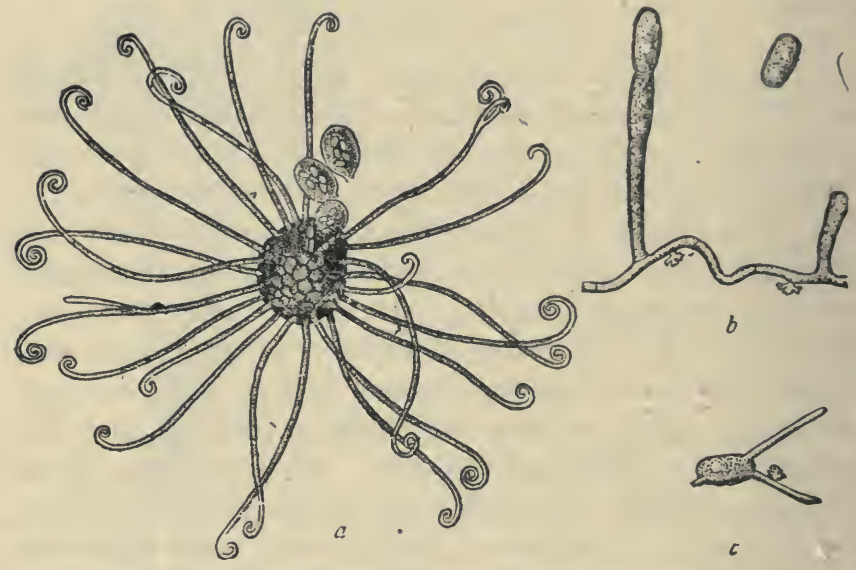

FIG. 42. POWDERY MLDEW. MAGNIFIED.

$a$, Perithecium; $b$, mycelium; $c$, germinating spore.

six small bodies, which are the winter spores. By means of these the fungus passes through the winter.

Microscopic Characters.-A good idea of the structure of this powdery mildew may be obtained from Fig. 42. A small piece of the mycelinm running over the surface of the leaf is represented in $b$; on the lower side are two of the peculiar suckers which penetrate the tissues of the host-plant to draw out nourishment for the fungus, and on the upper side are represented the vertical branches from which the summer spores are produced, as well as one loose spore. In $c$ one of these 
spores is shown in process of germination, one of the germ tubes having already formed a sucker on its side. 'The winter spore case, with the inner cases escaping through its ruptured side, is well shown in $a$.

Treatment.-This disease may easily be prevented. According to Mr. Galloway, "it succumbs readily to sulphur, either in the form of flowers of sulphur, or solutions of the sulphide. In applying the sulphur, bellows should be used, and the first applications should be made ten or twelve days before the flowers open, the second when in full bloom, and a third three wceks or a month later if the disease seems to be on the increase. The best results are obtained with the thermometer ranging from $80^{\circ}$ to $100^{\circ} \mathrm{F}$. In this temperature fumes are given off which quickly destroy the fungus. We have obtained excellent results in treating this disease with a solution made by dissolving half an ounce of potassium sulphide to the gallon of water. This preparation is cheap, and can be quickly and effectually applied with any of the well-known spraying pumps. The greatest care should be exercised in making the second spraying, which, by the way, should be at the same time as that mentioned for the flowers of sulphur, in order to protect the blossoms from the fungus."

Literature.-An excellent account of this fungus, from the pen of Professor Scribner, may be found in the Report of the United States Department of Agriculture for 1886 (pp. 105-109). There are many shorter articles concerning it scattered through our horticultural literature.

\section{The Grape Anthracnose}

\section{Sphaceloma ampelinum}

The peculiar and characteristic injury produced by the fungus of anthracnose easily distinguishes it from the other diseases of the vine. It attacks all the 
green parts of the plant, usually doing most damage to the young shoots and the fruit. On the former it ap-

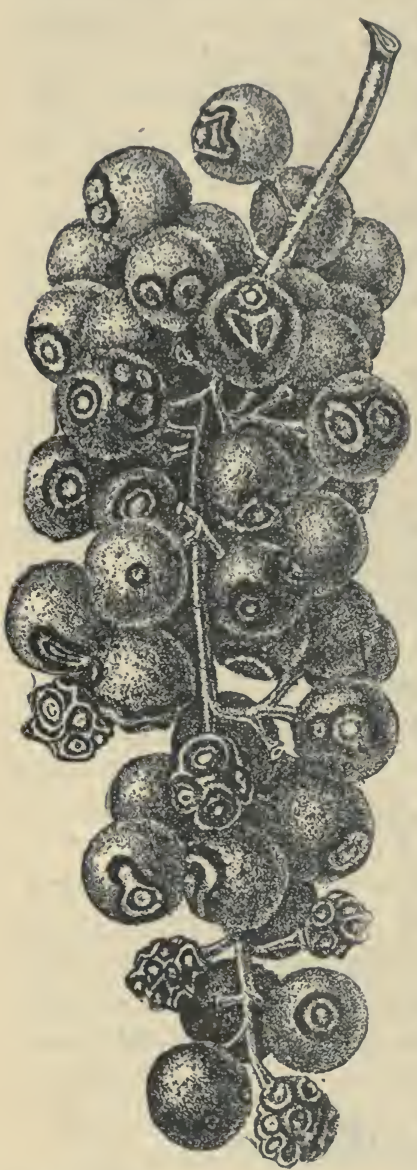

FIG. 43. ELVIRA GRAPE AFFECTED BY ANTHRACXosE. pears at first in the shape of small sound brown spots, depressed in the center, and having a slightly elevated dark colored border. As the shoots grow the spots gradually elongate, and their midale portions become more distinctly depressed because of the killing of the tissue. The effect upon the fruit is well illustrated in Fig. 43 ; there first appears a small grayish spot, having its margins dark brown. The spot gradually enlarges, and there is frequently developed just inside the dark brown margin a bright vermilion ring. On account of this, the disease is often called the "Bird's-eye" Rot. As the fungus progresses the growth of the berry is checked, and it finally becomes a dry, withered mass of skin, surrounding the partially developed seeds. The manner of development upon the leares is similar to that upon the green shoots. Like other fungi, the anthracnose fungus reproduces by means of minute spores, some of which are represented, highly magnified, at Fig. $44 c$. 
When one of these spores falls upon a green leaf, stem or fruit where there is a particle of water, it sends out a germinating tube, which penetrates the skin or cuticle. On the inside it begins the production of mycelium which grows near the surface, and finally produces, in certain spots, quantities of spores. These masses of spores gradually push the skin outward, as shown in $\alpha$, and finally rupture it and escape, as seen in $b$. They are then blown and washed about, and such of them as alight on the green parts of other vines when conditions are favorable for germination, start the fungus again.
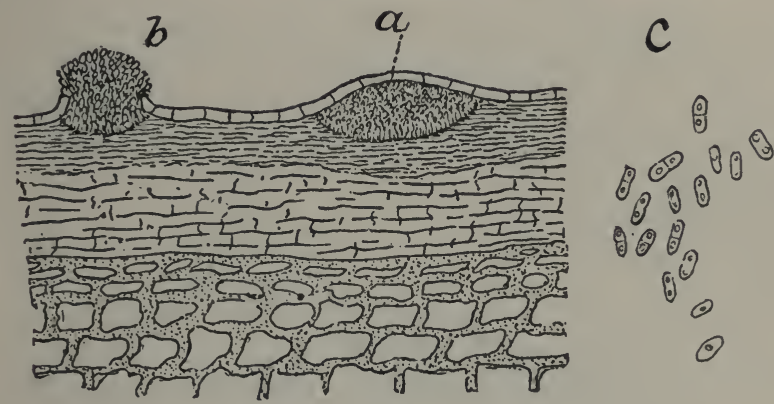

FIG. 44. ANTHRACNOSE.

$a, b$, Vertical section of grape showing development of spores; $c$, spores. Magnified.

The light colored and white varieties of grapes are the ones most affected by anthracnose. A bunch of Elviras injured by this disease is represented in Fig. 43.

Treatment.-This is a difficult disease to prevent. The treatment usually recommended is to cut out all injured canes during winter, and early in spring, before the buds start, to spray the vines thoroughly with a strong copperas (iron sulphate) solution. Mr. E. P. Powell has reported successful results from a solution of ten pounds of copperas to a barrel of water. In case the disease appears, a powder composed of equal parts 
of sulphur and lime may be dusted on; or the Bordeaux mixture may be applied.

Literature.-Professor F. L. Scribner has published, in the Report of the United States Department of Agriculture for 1886 ( $p$ p. 113-115), an extended account of grape anthracnose. Since then it has been frequently treated of in The Journal of Mycology, and in experiment station bulletins and reports.

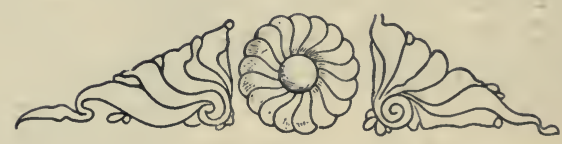




\section{FUNGI AFFECTING THE CURRANT AND GOOSEBERRY}

\section{The Leaf=spot Disease}

Septoria ribis and Cercospora angulata

The foliage of currants and gooseberries is often attacked early in summer by two or more species of fungi, which produce small brownish spots, at first often no larger than a pin head, but gradually increasing in

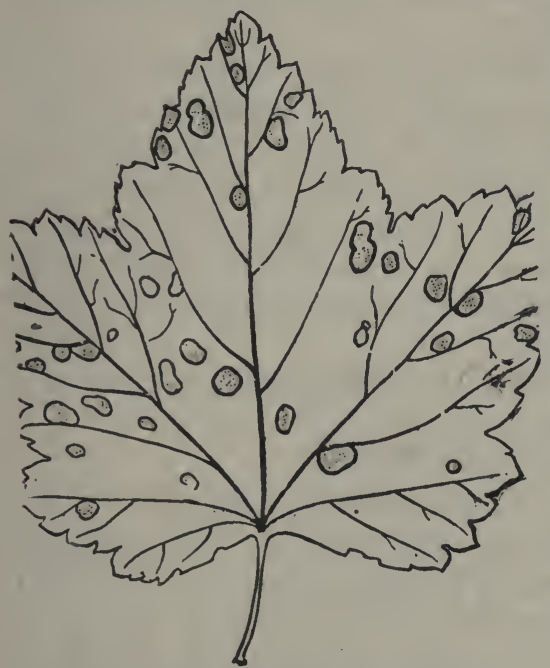

FIG. 45. SPOT DISEASE OF CURRANTS. size until a considerable proportion of the leaf surface is a ff e c ted. Sometimes several spots may run together, forming a large blotch; and these blotches, as well as the older spots, are often of a dead gray color. When the leaves are badly attacked they fall prematurely, so that the bushes may become as bare in August as they ordinarily are in December. Of course, the effect upon the plants of such a loss of foliage is disastrous. If a heary crop is already hanging the plant may be unable 
to ripen it; and, in any case, it has no opportunity to store up vitality for the coming season's fruitage.

The life-histories of the two species of fungi concerned in the attack do not seem to hare yet been definitely worked ont. Sometimes the Cercospora is the cause of the disease, and sometimes the Septoria. The spores apparently pass the winter in connection with the fallen leaves.

Treatment.-Spraying with some fungicide, like the ammoniacal copper carbonate solution, promises to be a preventive of this disease. The first application should be made early - soon after the leaves fully expand. Gathering and burning, or composting the fallen leaves, will prove helpful in destroying the spores. In case the leaves are composted, the resulting fertilizer should, of course, be applied to some crop away from any currant or gooseberry bushes.

Literature.-This spot disease has been discussed by Professor A. B. Seymour, in the report of the Minnesota State Horticultural Society for 1886 (v. XIV, p. 219); by Professor L. If. Pammel, in Bulletin No. 13 of the Iowa Experiment Station (pp. 6\%-70); and by Dr. B. D. Halsted, in the report of the New Jersey State Horticultural Society for 1889 (p. 156).

\section{The Currant Anthracnose}

\section{Glocosporium ribis}

This disease has only attracted attention in this country during recent years, and has been especially studied in New York by Professor Dudley (Cornell Experiment Station, Bulletin XV). It first appears in June or the early part of July, in the shape of small, dark brown or blackish spots, about one-twenty-fiftl of an inch in diameter, chiefly on the upper leaf surface. The spots enlarge, and the cuticle of the leaf is pushed 
upward by the developing spores, which escape through a small opening, in a peculiar, tendril-like mass, the individual spores being held together by a mucilaginous substance. The raising of the cuticle gives the spots a white or grayish tint. The infested leares become dull brown or yellow in color, and drop off, commencing sometimes by midsummer, and defoliating the bushes in Angust. Of course, the fruit on bushes so defoliated does not mature properly. Spraying with fungicides, such as the ammoniacal solution of copper carbonate, is recommended to prevent this disease.

\section{The Gooseberry Mildew}

\section{Sphorotheca mors-uvœ}

For many years it has been impracticable to grow the finer foreign varieties of gooseberries in the United States, on account of their liability to injury by the gooseberry mildew. This fungus usually appears in spring upon the partially developed leaves and buds, first showing as a sparse, cobwebby covering, which, later, is made to appear white and powdery by the production of the summer spores. The young berries are also attacked, generally being dwarfed and one-sided as they develop. As the summer progresses the infested leaves become brown and dead, and are generally covered with a thick growth of the fungus mycelium.

With most of parasitic fungi treated of in these pages the mycelium, or vegetative portion of the fungus is internal; that is, it develops inside the outer cuticle of the host-plant, among the cells of leaf, stem or fruit, sending out its fruiting branches when it has completed its growth. But with the class of so-called "powdery mildews," to which the present species belongs, the mycelium is external, developing on the outside of the host-plant. The mycelium consists of slender white 
threads which run over the surface of the leaf, and obtain nourishment by sendung down into the cells short branches, often called suckers. During the summer these threads also send upward in the air certain other branches, which gradually divide into a number of parts, as shown in $a$, Fig. 46, and thus produce the summer spores, or conidia. These summer spores are very light, and are blown about by the wind; when one falls upon a damp gooseberry leaf it germinates by sending out a slender tube, from which the mildew starts anew. As the summer spores are unable to survive the winter, the fungus produces, especially late in the sea-

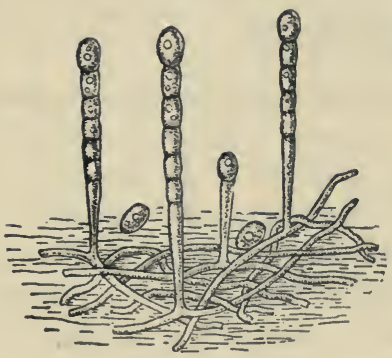

$a$

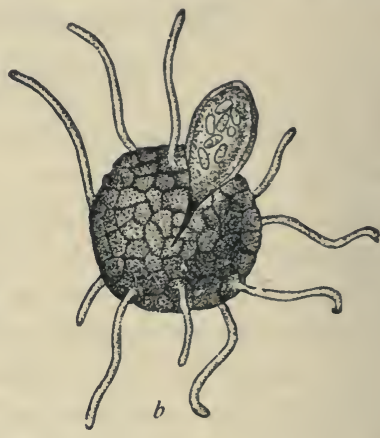

FIG. 46. SPORES OF GOOSEBERRY MILDEW. MAGNIFIED.

son, another kind of spores, the so-called winter spores. These are much more complicated in structure than the others. As seen under the microscope, they consist externally of a small round case, from which project about a dozen short delicate appendages, like those represented in $b$, Fig. 46. This is the outer spore case (called by botanists the perithecium). If it be crushed it will break open on one side, and there will be pushed out a flattened oval body-the inner spore case, or ascus - within which may be seen eight small bodies, which are the spores $(b)$. By means of these the fungus survives the winter. 
Treatment.-Spray with a solution of potassium sulphide (liver of sulphur) at the rate of one-half ounce to one gallon of water. Begin as soon as the leaves commence unfolding, and repeat the application at intervals of eighteen to twenty days. The sulphide dissolves more readily in hot than in cold water. This treatment has proven entirely efficacious for a number of years at the New York Experiment Station. Early in the season the Bordeaux mixture may be used instead of the sulphide if more convenient.

Literature.-An excellent article concerning this disease, by Dr. B. D. Halsted, may be found in the Report of the United States Department of Agriculture for $188 \%$ (pp. 373-380). It has also been discussed in the reports and bulletins of the New York Experiment Station, and in various books and papers on horticultural topics.

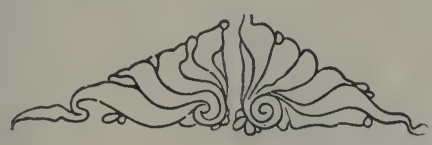




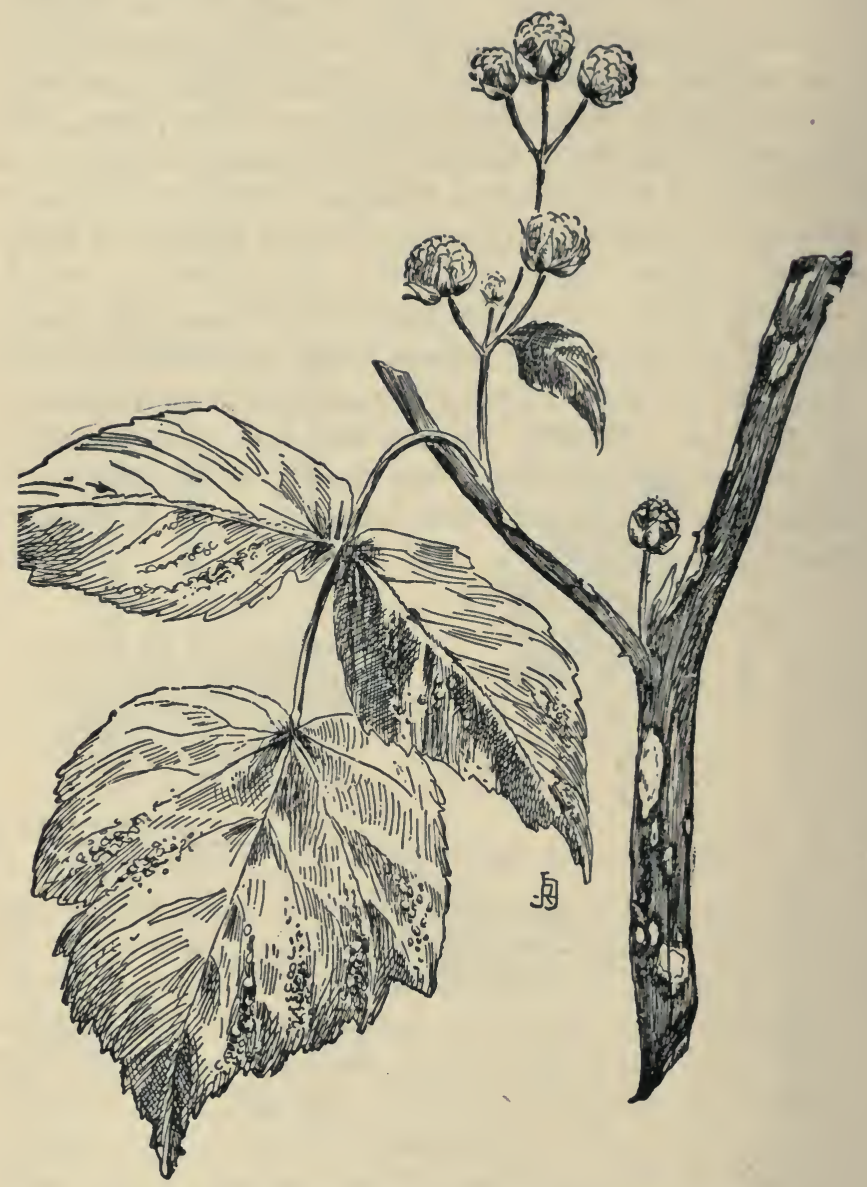

PLATE X. RASPBERRY AFFECTED BY ANTHRACNOSE. 


\section{FUNGI AFFECTING THE RASPBERRY AND BLACKBERRY}

\section{The Raspberry Anthracnose}

\section{Gloeosporium venetum}

Although this fungus is a widespread enemy of raspberries and blackberries, public attention was first called to it only about twelve years ago, when Professor T. J. Burrill published an account of it, under the name Raspberry Cane Rust, in the Agricultural Review. Fruit growers frequently call the disease "sun scald," but its more proper name is anthracnose.

This fungus especially infests blackcap raspberries and the thornless varieties of blackberries. It appears both upon the canes and leaves. On the former it may generally be found late in spring or early in summer on the young shoots, when about a foot high, in the shape of small reddish-purple spots, scattered irregularly over the surface near the ground. As the canes grow these spots increase rapidly in size, their centers becoming grayish-white, and other spots appearing on the upper portions. There is an elevated dark purple margin around each spot, representing the division between healthy and diseased tissues. As the season adrances the spots continually enlarge, many of them finally running together to form irregular longitudinal blotches, which sometimes run clear around the cane and thus girdle it. The injury extends through the outer bark, frequently rupturing it, and sapwood (cambium layer), but usually does not penetrate the pith. As the tissue 
is killed the purple color of the margin changes to brown. The purple spots also appear on the stems of the lower leaves, gradually extending outward, until the whole leaf stem may be affected. Minute purplish dots are also to be found upon the leaves themselves, indicating that the fungus is developing there. In the center of many of the spots one may often see little raised patches consisting of the spores.

Of the effect of raspberry anthracnose, Miss Freda Detmers says: "The disease is not fatal the first season, nor does it seem visibly to effect the growth of the young canes; but the next season, when last year's young canes bear fruit, its destructiveness becomes but too apparent (Plate I, Frontispiece). The effects of the fungus are most noticeable at the time of the ripening of the berries, which do not attain to a normal size, but. shrivel, and finally dry up; the leaves are much smaller than healthy ones, and have a generally unhealthy appearance, later turning yellow, then brown. The canes finally become blackened and die."

The mycelium, or vegetative portion, of the raspberry anthracnose consists of slender, microscopic threads which penetrate between the cells of the plant, and absorb their nourishment; the.cells thus robbed become first discolored, and then they shrivel and dry up, the tissues finally becoming dead. Toward the center of this dying tissue the mycelium threads unite to form a mass of slender club-shaped bodies (basidia), which push outward on the thin bark cuticle, or skin, until the latter is ruptured. On the end of each of these club-shaped bodies there is produced a single spore (conidium). Both the club-shaped bodies and the spores are at first enveloped in a yellowish, gelatinous covering, which, however, is soluble in water, so that during the first rainfall it dissolves and the spores escape. The shape of the spores is represented in Plate XI; they 


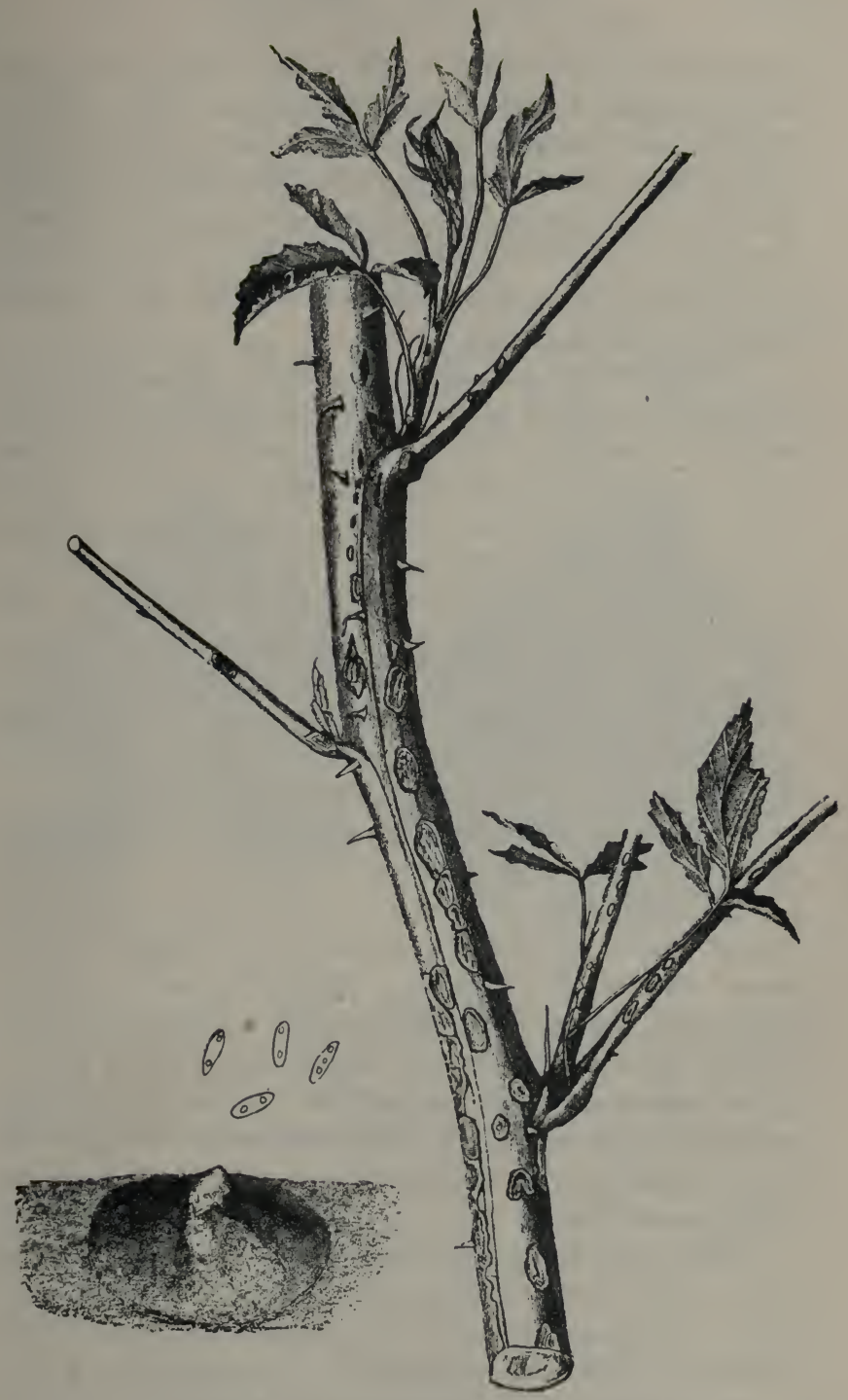

PLATE XI. AXTHHACDUSE OF RASPBERRY. 
are carried to new places on the plant during rains, and there they germinate and start the disease anew. Many of them are probably blown from plant to plant and field to field by the wind, and thus the disease is spread. All of these spores are the so-called summer spores (conidia); no true winter spores have yet been found. It is supposed that the mycelium is perennial, carrying the fungus through the winter.

Treatment.-Raspberry foliage is very sensitive to the corrosive action of fungicides, so that care in treatment is necessary. The most successful results in preventing this disease, as yet obtained, are those reported by $\mathrm{Mr}$. W. J. Green, of the Ohio Experiment Station, who used a dilute Bordeaux mixture. His directions are as follows: "The first application should be made early in the spring before the leaves open, at which time the spraying should be very thoroughly done. The second application should be made soon after the young canes appear above ground, and the spray directed to them alone. The third application is to be made about two weeks from the date of the second, taking the same precaution to spray the young canes only. The fourth and last application should be made just previous to the time of blooming, in the same manner as advised for the second and third sprayings. Raspberry leaves are very tender and the mixture injures them slightly, but not enough to preclude its use, especially if some care is taken to keep it off the leaves of the bearing canes. The leaves on the young shoots of the current season's growth are not so easily harmed, hence no pains need be taken to keep it off them."

Mr. Green also reports good results from the ammoniacal copper carbonate solution, "with even less harm to the foliage, but, all things considered, the dilute Bordeaux mixture is preferred." It is advisable to cut out and burn all fruiting canes each summer as soon as the crop is gathered. 
The most extended account of this disease is published in the 188\% Report of the Department of Agriculture (pp. 35\%-361).

\section{The Orange Rust}

\section{Cceoma nitens}

The orange rust, or red rust, of blackberries, is familiar to most growers of small fruits. The disease becomes noticeable as soon as the foliage expands in

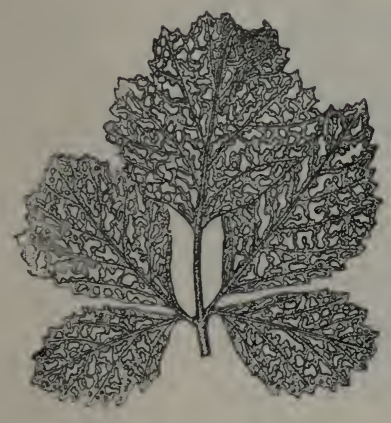

$a$

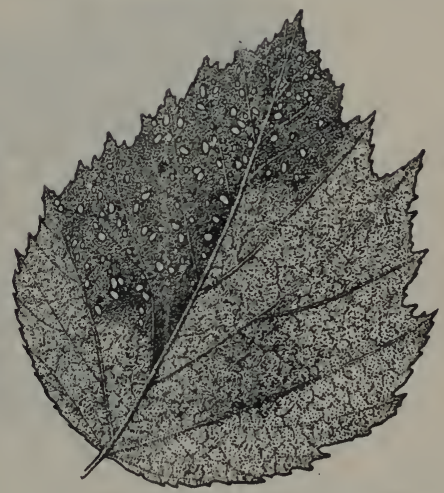

$b$

FIG. 47. ORANGE RUST.

$a$, Under surface of blackberry leaf showing splots of recidium stage: $b$, same of raspbery leaf showing both æeidium and Puccinia spots.

spring, affected leaves having a peculiar golden color, which at once distinguishes them. A little later the surface becomes more or less covered with small round patches of orange-colored spores, to which the common name is due. The life-history of the fungus has only recently been definitely worked out.

The fungus exists on the blackberry plant in two very different stages. The orange spores that are developed in spring and early summer, as shown in Fig. 48, belong to the cecidium stage. They germinate on the 
leaves of raspberry and blackberry; the germinating tubes enter the stomata, or breathing pores, of the leaf, develop a mycelium inside, and finally produce on the surface the spores of the teleuto stage, which has heretofore been considered an entirely different fungus, called by botanists Puccinia peckiana. These Puccinia spores are believed to be washed on to the underground

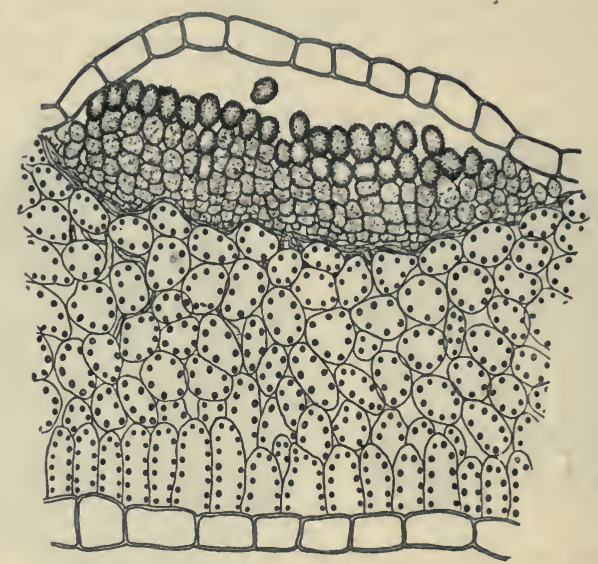

FIG. 48. SECTION OF BLACKBERRY LEAF, SHOWING DEVELOPMENT OF ORANGE RUST SPORES. MAGNIFIED.

shoots, and to infect them with the mycelium, which subsequently produces the orange spores of spring.

Blackberries are most commonly affected by this fungus-especially certain varieties-but blackcap raspberries often suffer also.

Treatment._All diseased canes should be cut out and burned as soon as they show signs of disease, leaving none to develop spores to infect other plants. In considering varieties, select-other things being equal-those least liable to the disease. Insist on your neighbors keeping the rust in check, and also look out for wild plants that have it. A spraying with fungicides will 
doubtless assist in preventing infection, especially of the Puccinia stage.

An extended account of this disease, by Mr. G. P. Clinton, occurs in Bulletin 29 of the Illinois Experiment Station.

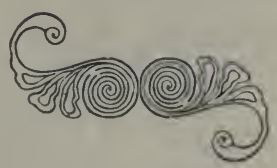




\section{FUNGI AFFECTING THE STRAWBERRY}

\section{The Strawberry Leaf=blight}

\section{Sphcerella fragarice}

The strawberry leaf-blight, leaf-rust, or leaf-spot is the most destructive of the numerous fungous enemies of this delicious fruit. The disease apparently occurs in the United States wherever strawberries are grown, having been recorded from Maine in the north and east, to Florida in the south, and California in the west. Over a large portion of this vast territory it frequently becomes very seriously injurious.

This fungus first appears on the upper surface of the leaf in the shape of small purplish or reddish spots, which, though minute at the start, increase rapidly in size. Their centers also gradually become lighter in color, changing from purple, or reddish, to brown, then to gray or white, but the margin generally remains purple. The size of the spots varies greatly, single ones sometimes being a quarter of an inch in diameter, and others running together to form large discolored blotches. Badly affected leaves finally wither, turn brown and die. The vitality of affected plants is seriously impaired, and if they are not killed outright, the crop of fruit produced by them is diminished.

Professor $\mathrm{H}$. Garman says that if one of the diseased spots "be cut through with a pair of fine scissors, the leaf will be found, at the point where the spot is formed, much thinner than elsewhere, because of the killing and drying out of its substance. Examined under a microscope the fungus may now be found to 104 
have pushed through the tissues of the leaf, and to have formed all over the brown central region of the spot, but most abundantly at its margins, small whitish tufts, looking like microscopic shrubs. These are the fruiting parts of the parasite, and are made up of numerous

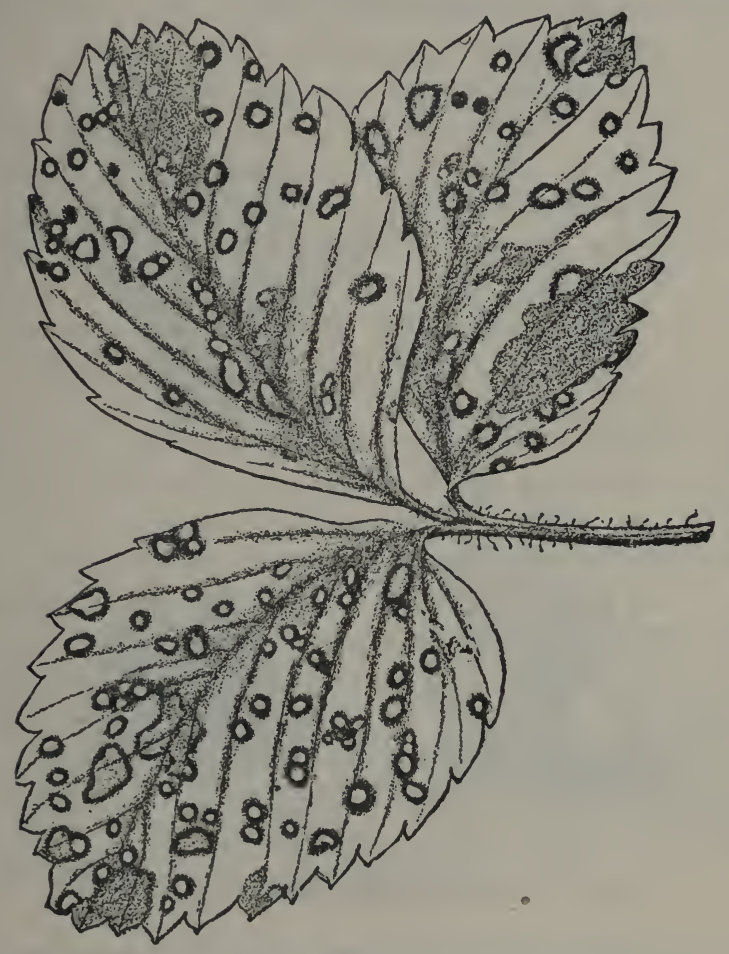

FIG. 49. STRAWBERRY LEAF AFFECTED WITH BLIGHT.

threads, each bearing at its summit a long jointed spore. As these latter ripen they are set free, and are scattered upon fresh leaves by winds and rains, to germinate there, push into the leaves and form new spots." The fungus is propagated by these long spores throughout 
the summer, but in autumn the threads of mycelium "form solid tissue-like masses in the dead parts of the spots," which finally appear at the surface as small black dots. By means of these dots or nodules, (which are called by botanists schlerotia) the fungus mainly passes the winter, but Professor W. R. Dudley has shown that
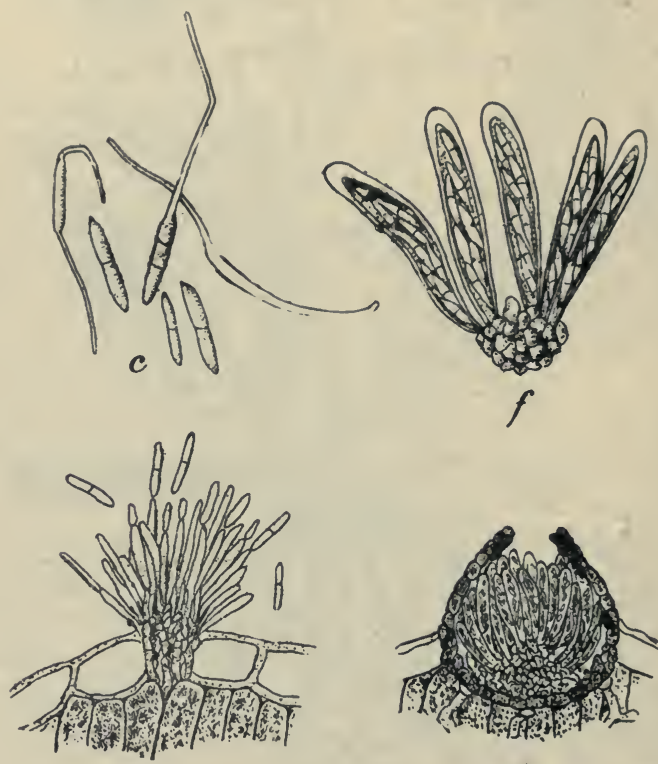

$b$

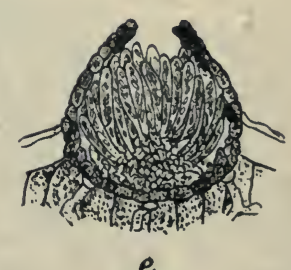

FIG. 50. LEAF-BLIGHT FUNGUS. MAGNIFIED.

it is also carried through the winter by the mycelium in the leares, and the so-called winter spores, or ascospores.

Microscopic Characters. - The process of development of the summer spores, or conidia, is represented in $b$, Fig. 50, which shows a tuft of them after having broken through the upper epidermis of the leaf. At $c$ may be seen some of the individual conidia, three of 
which have sent out germinating tubes. The winter spores within their cases, as they are borne on the leaf in partially closed sacs-called perithecia-are seen in $e$, and at $f$ some of these cases containing spores are represented more highly magnified.

Treatment.-It has been repeatedly shown that this leaf-blight may be prevented by the Bordeaux mixture. Usually spraying after the crop is gathered, especially when the plantation is mowed and burned over, keeps the disease sufficiently in check, but additional spring sprayings-one when the new leaves start, and another just before the blossoms open-will prove of much benefit. Young, non-bearing plantations should be sprayed two or three times during summer.

Literature.-The strawberry leaf-blight has frequently been discussed in the American literature of plant diseases. In 1885 Professor Wm. Trelease published an article concerning it in the report of the Wisconsin Experiment Station for that year (pp. 47-58). Professor F. L. Scribner has an elaborate account of it, illustrated by a colored plate, in the report of the United States Department of Agriculture for 1887 (pp. 334-341). Other articles concerning it have been published by Professor Arthur in the report of the New York Experiment Station (1888, p. 351); by Professor Dudley, in the Bulletin of the Cornell University Experiment Station (XIV); and by Professor Garman in the Bulletin of the Kentucky Experiment Station. 

PART III

FungI AFFECTING SHADE TREES,

ORNamental Plants AND Flowers 


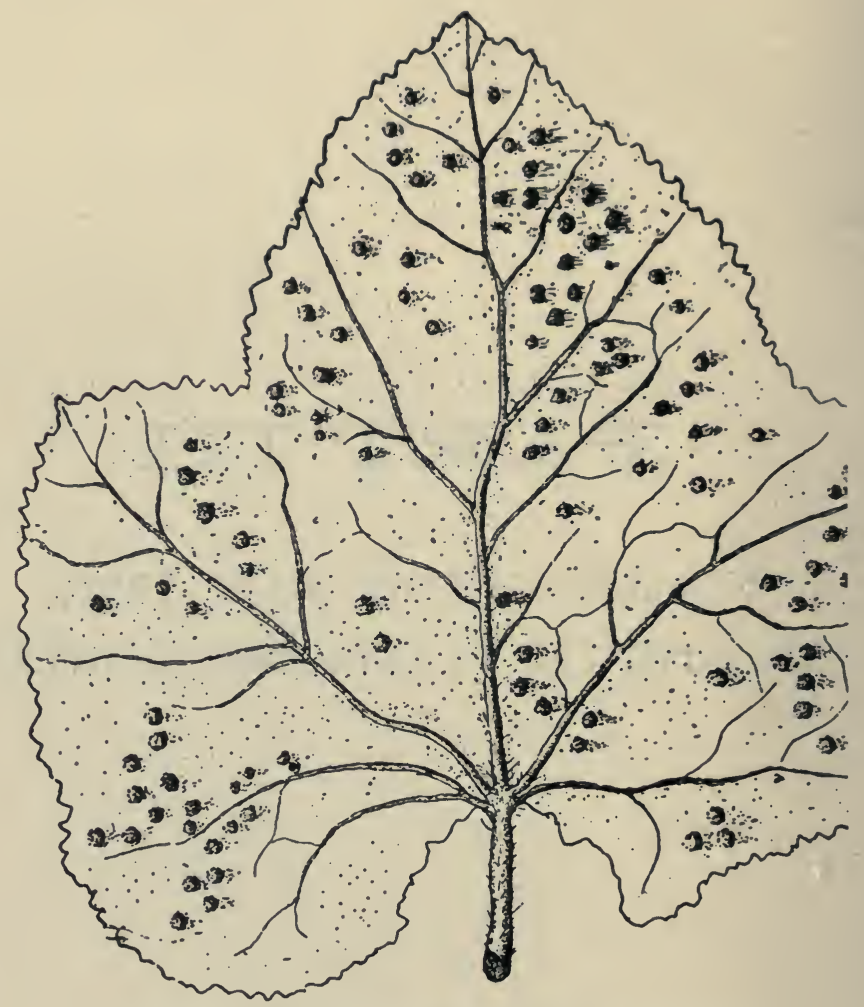

PLATE XII. HOLLYHOCK JEAF AFFECTED WITH RUST. 


\section{FUNGI AFFECTING SHADE TREES}

\section{The Catalpa Leaf=spot Disease}

Phyllosticta catalpoe

Early in summer small discolored spots frequently appear in the leaves of Catalpa trees. Although minute at first they gradually enlarge, and two or more often run together to form brown or blackish blotches, which sometimes involve most of the leaf. In badly affected trees the tissues of the leaves may be so diseased as to cause defoliation during the latter part of summer. In less severe cases the affected areas may drop out of the leaves, round holes appearing in their stead.

This disease is caused by a fungus which originates in spores like those represented in Fig. 51, $b$. When one of these spores falls upon a moist catalpa leaf it germinates by sending out tubes, as illustrated in $c$, of the same figure, and these germ tubes enter the leaf-tissues, where they develop a mass of mycelium, which grows at the expense of the leaf cells, the latter becoming disorganized and turning brown. After the mycelium has developed in this way for some time it produces spores in certain parts of the spot, rupturing the skin, or cuticle, of the leaf, to enable the spores to escape, as shown in $a$. These spores are blown or washed upon other leaves where, under favorable conditions, they may germinate and start new spots. There is another fungus, quite different in microscopic characters from the one illustrated, usually found on the spots, but it is believed to be a secondary form growing on the disorganized 
tissues, which the fungus under consideration first produces.

Treatment.-The burning of fallen catalpa leaves in autumn is an advisable preventive measure. Probably early sprayings with Bordeaux mixture, or some similar fungicide, would prove an effectual remedy.

The only important article on this subject that has come to the writer's notice may be found in the report

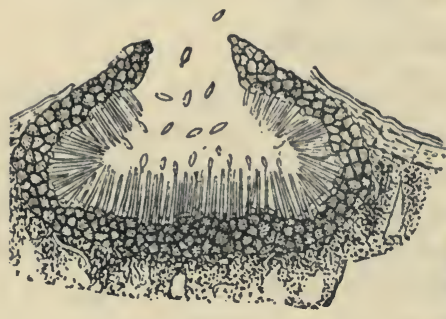

$a$

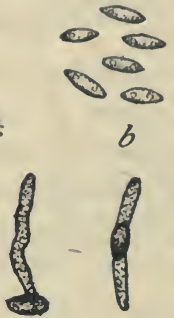

b

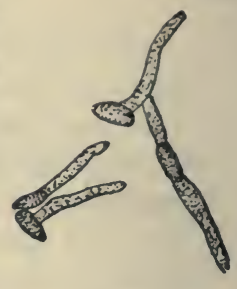

$c$

FIG. 51. CATALPA LEAF-SPOT.

$a$, Section showing spore production; $b$, spores; $c$, spores germinating. Magnified. of the United States Department of Agriculture for 1887 (pp. 364-366).

\section{The Cottonwood Leaf=rust}

\section{Melampsora populina}

The leaves of poplars and cottonwoods are quite commonly covered on the underside with an orange colored powder, which consists of the spores of a rust fungus. Such leaves usually fall prematurely, so that the trees may be defoliated long before the proper time. Later in the season the orange powder is replaced on the leaf by reddish brown, waxy pustules. 'This is the winter stage of the fungus. Raking and burning fallen leaves is advised, as a remedial measure. This fungus is discussed in the 1888 Report of the Department of Agriculture (pp. 390-392). Recent experiments have 
shown that this malady may be prevented by early spraying with Bordeaux mixture.

\section{The Sycamore Blight}

\section{Gloeosporium nervisequum}

The tips of branches of sycamore trees often exhibit a peculiar injury in spring, which is commonly attributed to frost. The leaves turn brown, presenting a scorched appearance. The effect is really due to a parasitic fungus, which produces its fruit in minute black pustules that may be found on the injured leaves. No remedy, except that of cutting and burning affected twigs-impracticable in most cases-has been suggested. The disease is discussed in the report of the Department of Agriculture for 1888 (pp. 38\%-389).

\section{The Maple Leaf=spot Disease}

\section{Phyllosticta acericola}

The leaves of various species of maple are often attacked by this fungus, which appears late in spring or early in summer in the shape of minute, blackish circular spots. As the mycelium inside the leaves develops the spots increase in size, and their color often becomes more brownish, the shade differing considerably with the various kinds of maple. Many of them finally become a half inch or more in diameter, and two or more often run together to form a large blotch; in case of severe attacks so much of the leaf-surface may be affected that the foliage withers and falls from the tree.

The disease could probably be checked by fungicides, but the application of these to large numbers of shade trees is usually impracticable. In nurseries, however, they may be employed. Gathering and burning the fallen leaves helps to check it by destroying the spores. An illustrated discussion of this fungus may be found in the Department of Agriculture Report for 1888, pp. 383-386. 


\section{FUNGI AFFECTING THE ROSE}

\section{The Rose Mildew}

Spherotheca pannosa

The mildew of roses is probably familiar to every one who has grown these plants in a greenhouse. The characteristic covering of mildew upon the leaves is very likely to appear if the roses are neglected in any way. Professor S. T. Maynard says that "long experience in growing the rose has led many to believe that the rose mildew is brought on by various conditions that weaken the vigor of the leaf, such as want of an abundance of plant food in a proper condition, unhealthy condition of the soil, often resulting from improper drainage, irregular or over-watering, or too sudden changes of temperature, especially after the plants have been forced at a high temperature. The successful rose grower, therefore, is one who, by constant care and good judgment, always provides against any or all of the above causes."

Treatment.- The ordinary method of preventing the mildew is to close the house and fill it with sulphur fumes three times a week. The sulphur may be put in a thin iron kettle over a small kerosene stove, placed where there is no danger of upsetting, and only fire enough should be turned on to boil the sulphur. If it catches fire the plants in the house might be ruined. Probably spraying with copper carbonate solution, or a similar fungicide, would also prove an effectual preventive. 


\section{The Rose Rust}

\section{Phragmidium mucronatum}

This is a distinct and easily recognized affection of roses which has long been known, both in Europe and America, to lovers of the queen of flowers. It seldom attacks tea roses, usually confining its attention to the hardy hybrid perpetuals. It generally appears early in summer in the form of orange-yellow spots upon the leaves, their petioles, or the green growing stalks. At first these spots are small, but they grow in size, especially on the leaf petioles and young shoots, where they generally bacome elongate, while the petioles and shoots often become twisted and otherwise deformed. About midsummer the orange-yellow color gives way to a brickred color, the latter appearing on the same spots and being due to the production of a different kind of spore. Towards autumn still another kind of spore is produced, developing in small blackish masses, mostly on the under sides of the leaves. These masses consist of the so-called winter spores, which live over winter among the fallen leaves, and in spring start the disease again.

Microscopic Characters.-This is one of those fungi which produce different spores at different seasons. The spring form, producing the orange-yellow spots on the leaves, is composed of the so-called acidio-spores. They are small spherical or angular bodies, which serve for the rapid spread of the disease as they are blown about by the wind. The spores forming the brick-red spots of midsummer are called the uredo-spores. They are borne on short pedicels, and though spherical in general outline, have the outer surface roughened by numerous projecting points. One of the spores composing the black spots found late in the season-called by botanists the teleuto-spore-is represented at Fig. 52. It is yery different from either of the preceding forms, being cyl- 
indrical, divided into numerous cells by transverse partitions, and borne on a stout pedicel. According to Professor Scribner, these spores germinate the following spring by "sending out somewhat thickened tubes

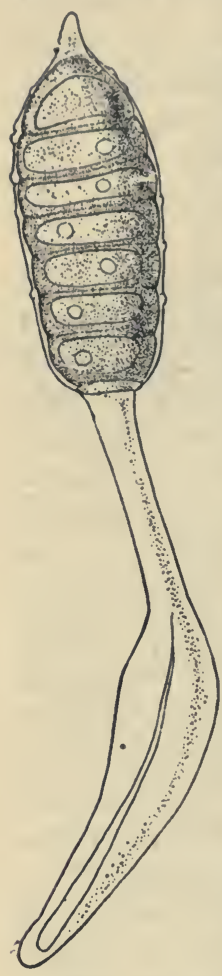

FIG. 52. WINTER SPORE. MAGNIFIED. (usually one tube issues from each cell), which, after attaining a length several times that of the spore, produce sereral minute globose bodies on short and slender stalks. These bodies, named sporidia, are easily wafted from place to place by the slightest currents of air, and when they fall upon rose leares where there is moisture they send out slender filaments, which probably bore their way through the cuticle into the interior of the leaf," where the mycelium is again developed, and the disease is started for another season.

Treatment.-Rose bushes should be watched early in the season, and as soon as any lemon-yellow spots are noticed the affected portions should be removed and burned. Raking up and burning at the end of the season, the leares beneath any bushes that may have been affected during summer, is advisable, on account of the winter spores so destroyed. It is well, also, to spray such bushes, and the ground beneath, during winter, with a solution of copper sulphate, or with some other fungicide. Probably spraying with the ammoniacal copper carbonate in spring, after the leaves expand, would prove helpful if needed.

A good account of this fungus, illustrated with a colored plate, may be found in the United States Department of Agriculture, Report for 1887 (pp. 369-371). 


\section{The Rose Phragmidium}

Phragmidium speciosum

'The peculiar appearance of this disease when attacking the stems of roses is well illustrated in Fig. $52 a$.

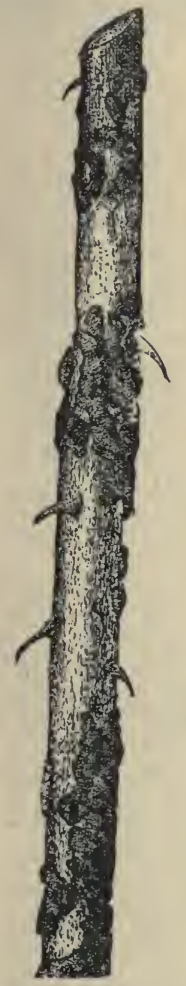

a

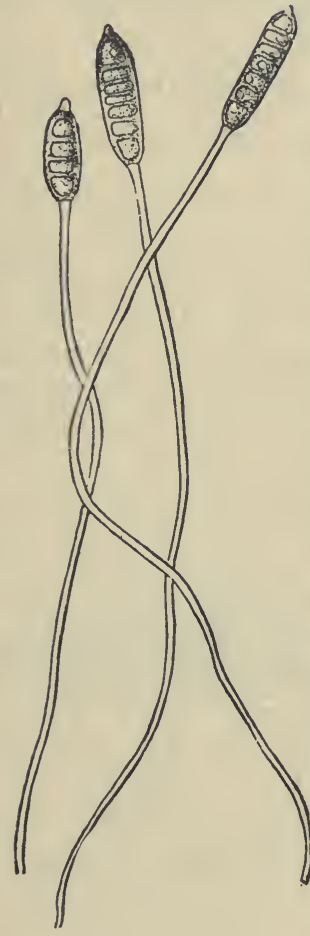

$b$

The bark of $\mathrm{such}$ stems is more or less cuvered with irregular black patches, consisting of vast numbers of the winter spores of the fungus, borne upon long slender stalks, as seen, much magnified, at $b$. The spores themselves are divided by transrerse partitions into from five to seven cells. The mycelium of this fungus develops in the inner bark and the cambium layer of the stems, but is believed not to penetrate into the woody tissue. Of course it interferes with the flow of sap, and when, as often happens, it extends clear around the stem, it may prove fatal to FIG. 52. ROSE PHRAGMIDIUM. $a$, Affected stem; $b$, winter spores. the plant. The mycelium is perennial in the stems, living from one season till the next, so that when once infested there is no way of ridding a plant of it. The 
only remedial treatment suggested is to cut and burn infested parts of bushes. Probably spraying or washing the stems with the Bordeaux mixture will prove advantageous in preventing the ingress of the parasite.

A short article concerning this fungus appears in the report of the United States Department of Agriculture for $188 \%$, Page $3 \% 2$.

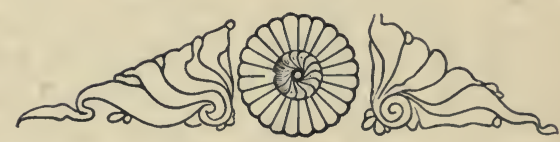




\section{FUNGI AFFECTING FLOWERS}

\section{The Hollyhock Rust}

\section{Puccinia malvacearum}

This fungus is a native of Chili, from whence, about 1869, it was introduced into Europe, where it has done much damage. It first appeared on hollyhocks in this country in 1886 , having been accidentally imported into Massachusetts the previous year on another plant. Since then it has gradually spread in various directions. It appears in May and June, in the shape of yellow or orange spots, on the leaves and stems of the hollyhock. These spots occur especially on the under surface of the leaves ; they increase rapidly in size, and the yellow color gives way to a brown. The spots, or sori, are composed of two-celled spores. When they are very abundaut they cause the plant to become sere and brown, preventing, in whole or in part, the production of flowers. A leaf showing the sori on the under surface is represented in Plate XIII.

Treatment.- When this disease appears in a new locality for the first time the best method will be to pull up and burn the affected plants at once. European gardeners have reported successful results from sponging all diseased parts of the plants with a mixture made by adding two tablespoonfuls of saturated solution of permanganate of potash to one quart of water. It seems probable that thorough spraying with some fungicide like the Bordeaux mixture or the ammoniacal copper carbonate solution,'would prove helpful. In any case, 
the fallen leaves and dead plants should be removed and burned.

'I'wo other hollyhock diseases commonly occur. The more abundant is the leaf-spot, due to the fungus Cercospora althceina. Leaves attacked by it show at first small distinct spots, which rapidly enlarge, often running together and destroying the entire leaf-tissue. It affects young, as well as old, plants, and frequently is very destructive.

The leaf-blight of hollyhocks is due to Phyllosticta atthceina. Affected leaves are usually not attacked in so many places as by the leaf-spot, but the injury in the infested area is more severe, the tissues being destroyed as the fungus spreads. Excellent illustrations of these diseases may be found in the American Florist (Jan. 25, 1894). The use of seed from non-affected plants, and spraying with Bordeanx mixture, are recommended as preventive measures.

\section{The Carnation Rust}

\section{Uromyces caryophillinus}

During recent years the growing of carnationsappropriately called the "divine flower"-has become one of the most important branches of the floral industry. In consequence, the fungous diseases of the plant have received unusual attention, and effective methods of preventing most of them have been discovered.

The carnation rust is the most important of these diseases. It first appears on the stem or leaf as a pale elevated pustule, over which the epidermis soon breaks, hanging on the edges in a ragged condition, and reveals a brown powdery mass which consists of the reproductive spores of the fungus. Like the other rusts, this fungus develops two kinds of spores, the uredospores, which may be likened to the conidia, or summer spores, of 
other fungi; and the teleuto-spores, which are the resting or winter spores. There is little difference, to the naked eye, except that the teleuto-spores are slightly darker in color. The uredospores are the ones by which the disease is rapidly propagated and spread. They may be blown or washed from plant to plant, spreading infection rapidly. Carnations of all ages are liable to injury, which is often so serious as to ruin large plantings.

Treatment.-The experience of a number of florists has shown that this rust can be prevented by the use of the dilute Bordeaux mixture, supplemented by careful hygienic methods. The application should be made upon the first appearance of the disease, or even before, if there is much danger of its presence, and repeated at occasional intervals. Instead of the liquid mixture, which it may not be desirable to use on plants in blossom, a dry preparation is used by some growers. It is made as follows: "Six pounds sulphate of copper dissolved in three or four gallons of boiling water, stirring till thoroughly dissolved; with this liquid and just enough added water, dry slake one bushel of lime (different limes require a slightly varying quantity of liquid to slake them.) Thoroughly dampen a tight wooden box, and put in a layer of the lime and sprinkle with the copper solution till it falls into a fine dust. Put in another layer and sprinkle, and continue till the bushel of lime is reduced to a dry powder." This powder is to be dusted over the foliage. Sulphide of potassium-one ounce to ten gallons of water-has also been successfully used.

\section{The Carnation Leaf =spot}

\section{Septoria dianthi}

This is a widely distributed and troublesome disease. It appears on the leares and stems in the shape of a more or less circular purplish spot with a whitish 
center, the latter often being dotted with black by the fruiting portions of the fungus. The fungus penetrates the stem rather deeply, often cutting off the supply of nutriment to the flowers, and, consequently, preventing their development. A plant injured in this way is represented in Fig. 53, from a photograph by Professor Atkinson. The spores are produced in great abundance,

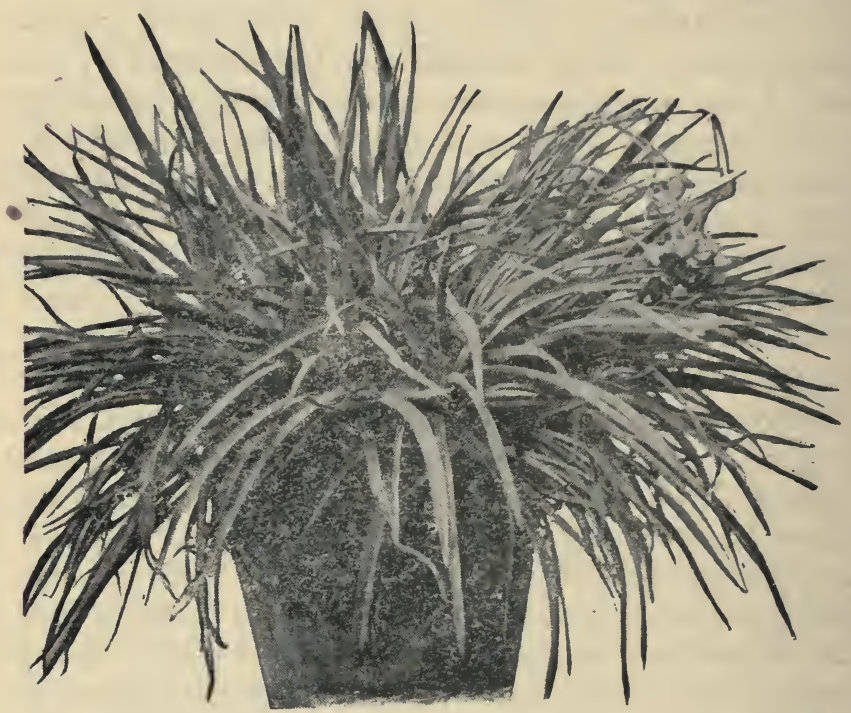

FIG. 53. CARNATION INJURED BY LEAF-SPOT.

and distributed by means of wind and water. Care in watering, and the use of fungicides, are the best remedial measures.

There are certain other carnation diseases, such as the anthracnose, the leaf-mold, and the rosette, which need hardly be discussed in this connection. Partial accounts of them may be found in American Gardening for April, 1893, where also the diseases treated of above 
are described. One of the fullest accounts of the carnation rust, by Professor Arthur, occurs in The American Florist, Feb. 18, 1892.

\section{The Mignonette Disease}

Cercospora resedae

Mignonettes frequently suffer from a disease which may first bo noticed, "either as minute pale spots with brownish or yellowish borders-little sunken areas in

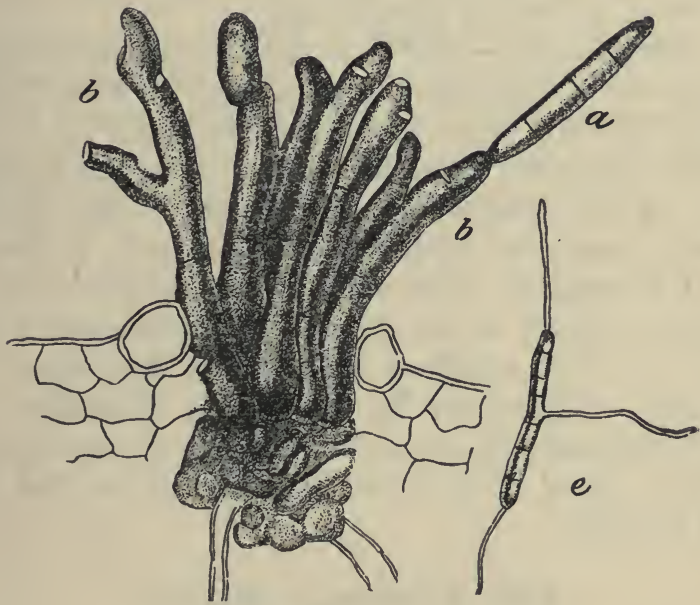

FIG. 54. MIGNONETTE DISEASE.

$a$, Spore; $b$, spore stalks; $e$, germinating spore. Magnified.

the succulent tissues of the leaf-or as reddish discolorations which spread over the leaf, and finally develop into these pale spots or patches." These spotted areas are portions of the leaf which the fungus has invaded and destroyed. As the mycelium develops within the leaf they increase in size, and finally involve so much of the surface that the leaf wilts and withers; the whole plant sometimes looks as if it had suffered severely from 
drouth. Black specks develop on the surface of the injured areas, giving it a granular appearance. These specks consist of the fruiting spores of the fungus. The young seed-pods are sometimes affected.

If one of the little black specks be looked at from the side under a high power of the microscope it will be seen to resemble Fig. 54, which represents a tuft of fruiting threads after they have burst through the skin of the leaf. At $a$ is seen a spore borne on the summit of one of these fruiting threads $(b, b)$, while at $e$ is seen a spore in process of germination.

Treatment.-Mr. D. G. Fairchild made some experiments in spraying the young plants with the Bordeaux mixture, from which he concluded that if the young plants are carefully sprayed with the Bordeaux mixture the trouble may be avoided. The spraying should be repeated whenever the spots begin to show.

Literature.-The only American articles of importance known to me are one by Professor A. B. Seymour in The American Florist for September, $188 \%$ (p. 38), and another by Mr. D. G. F'airchild, from which the above quotation is made, in the report of the United States Department of Agriculture for 1889 (pp. 429-432).

\section{The Verbena Mildew}

\section{Oidium erysiphioides}

This often proves a destructive enemy to verbenas under glass, appearing on the leaves and young stems as patches of white mildew. According to Professor L. H. Bailey, it may be prevented by spraying with sulphide of potassium (one-fourth ounce to a gallon of water) about twice a week. Probably the ammoniacal copper carbonate solution, or other copper fungicides, would prove equally effective. 


\section{The Petunia Blight}

Ascochyta petuniae

Petunia leaves are sometimes affected by a blight, which is likely to begin near the center and to spread in all directions. Sometimes rings are produced on the injured tissues. Like other fungi, this species reproduces by means of spores, which are developed in great numbers. The early application of fungicides is suggested as a preventive.

There are many other fungous diseases of flowers and foliage plants, but the limits of the present work prevent their discussion here. Illustrated accounts of many of them have been published by Dr. Halstead and others in The American Florist, Garden and Forest, The American Agriculturist, and other journals. 


\section{PART IV}

FunGI AFFECTING VEGETABLES 


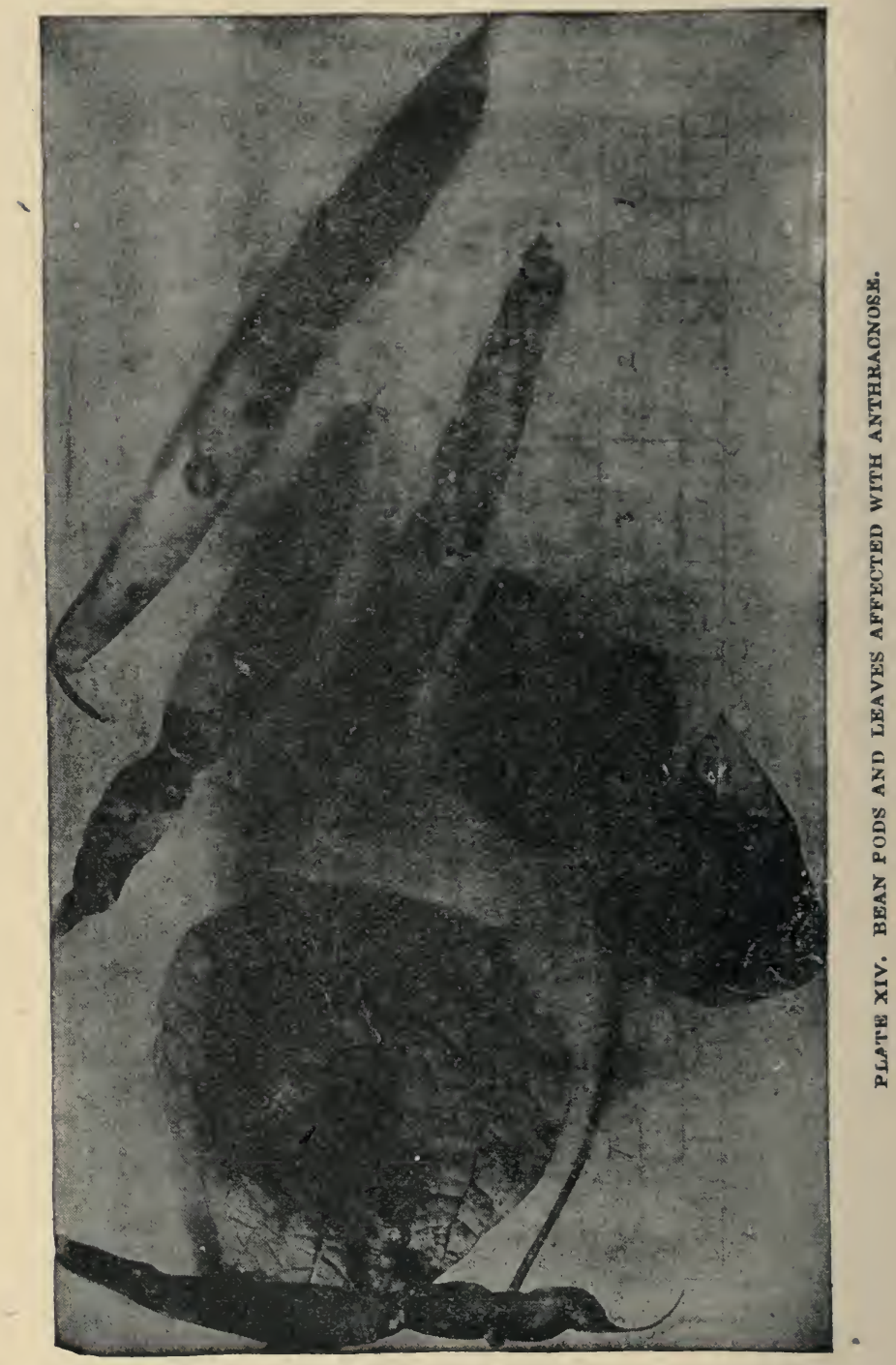




\section{FUNGI AFFECTING THE BEAN}

\section{The Pod=spot or Anthracnose}

\section{Colletotrichum lagenarium}

Young bean pods, especially of the yellow or wax varieties, are often affected by small reddish-brown spots, slightly sunken beneath the surrounding area. As the pods develop these spots increase in size, and their centers become blackened. In course of time many of them may run together to form long discolored blotches upon the sides of the pods, and generally the blackened centers eventually become of a dirty gray or light brown color. The effect ipon the pod of such an attack is disastrous; it is shrunken and out of shape, and the beans within are dwarfed and shriveled.

This disease is seldom destructive, except during seasons of rainy weather. It occurs in several European countries, and has been found orer a large portion of the United States. It winters over, in part, by means of diseased seeds, which, when planted, start the fungus again, and it spreads rapidly when sound and affected string beans are sent to market in the same receptacle. This same fungus attacks melons, and other cucurbitaceous plants, causing a rind-rot. Consequently, beans and melons shonld not follow each other in rotation, as the spores in the ground will cause trouble.

While the attack of this fungus on the pod is most noticeable, it does not confine itself to this part of the plant. In case diseased beans are used for planting, the attack may be noticeable as soon as the seed-leaves come up, and may develop so rapidly as to injure the 


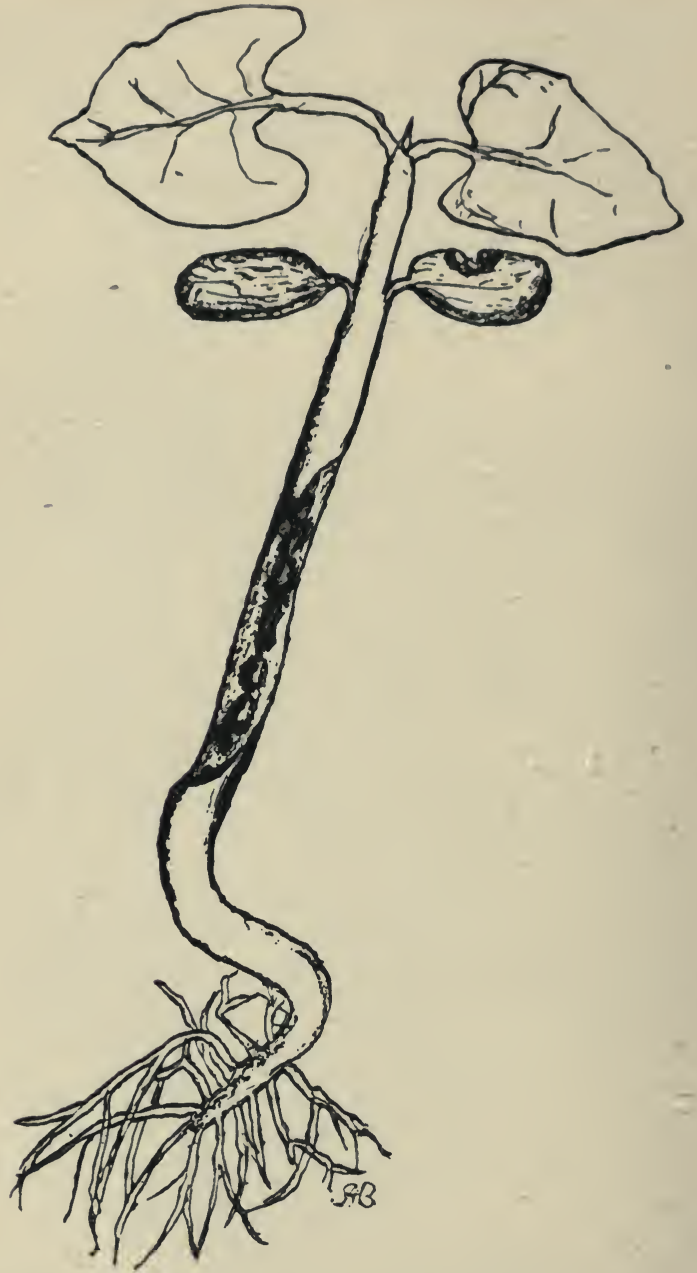

FIG. 55. BEAN PLANT ATTACKED BY ANTHRACNOSE. 
stalk (Fig. 56) and kill the plant. In this way a fourth of the seeds planted are sometimes killed off. As the leaves develop they are attacked, the veins becoming blackened, and discolored spots appearing. Dots of a light pink color appear on the middle of the spot shortly after it has formed. A microscopic examination will show that these dots consist of spore masses held together by a mucilaginous substance, which is readily soluble in water. When the enveloping mucilage is dissolved the spores are set free, to be blown or washed about, or carried to other plants by insects or other agencies.

Treatment.-Planting in a light soil, on high, well-drained land, is one of the best preventives of this disease. Experiments in New York have shown that it is well worth while to examine the seed beans carefully before planting and reject all that show signs of the disease. Then the young plants may be sprayed with dilute Bordeaux mixture, to which soap enough has been added to make a slight suds, applying first when the plants are two weeks old, and repeating two or three times at intervals of a week or ten days. Or soak the seed in dilute ammoniacal copper carbonate solution. In the case of string beans, where the pods are to be eaten, the spraying must cease earlier than with those crops where the beans themselves are to be harvested. 'The immediate removal and destruction of all plants or portions of plants which become affected is very desirable, as every plant so left becomes a center of infection. They should be taken away and burned or buried.

Literature.-The best article concerning this disease accessible to the American student was published by Professor Scribner, in the report of the Department of Agriculture for 1887 (pp. 361-364). It is illustrated by an excellent colored plate. Professor Trelease published an earlier account in the Cultivator and Country Gentleman (October, 1885). Other articles of especial 
value, because of their accounts of remedial treatment, will be found in the report of the New Jersey Experiment Station for 1891, and in Bulletin No. 45 of the New York Experiment Station. The latter account contains a list of sixteen articles, in which the disease is discussed.

\section{The Bean Rust}

\section{Uromyces phaseoli}

This is a decidedly different disease from the anthracnose of the bean. It commonly appears on both surfaces of the leaves in the form of small, round, brown, scattered spots, which at first are about the size of pin heads. These soon give off a brown powder, which is composed of the spores, or reproductive bodies of the fungus. In the course of the season the brownness of the spots changes to black. Often both brown and black spots may be found on the same plant at the same time. The blackness simply represents a later stage of development of the fungus. This disease is seldom destructive, and little has been done in the way of remedial treatment. Presumably spraying the plants with Bordeaux mixture will prove a preventive.

\section{The Bean Blight}

In some parts of America still another disease has proved destructive to beans. It appears to be due to bacteria. Mr. S. A. Beach says that "in its early stages this blight forms small pimples, which have a watery appearance. These may occur on the pods, blossoms (?) foliage or stems. They may or may not have a dull red border, but do not have either the black color or the sunken spots which characterize anthracnose. Microscopic examination in the early stages of the blight failed to reveal the presence of any mycelium, but bac- 
teria were always present. In later stages saprophytic fungi gained entrance through the diseased places and hastened the destruction which the bacteria had inangurated." 'The beans within the pods are also affected, many of them being more or less discolored and disfigured by the blight. Lima beans are also attacked by what is supposed to be the same disease. So little is known of this disease that the only remedial measures at present to be suggested are the burning of diseased vines, the selection of healthy seed, and crop rotation.

\section{The Lima Bean Mildew}

\section{Phytophora phaseoli}

This fungus first attracted attention two or three years ago, in the vicinity of New Haven, Connecticut, where it was carefully studied by Dr. Roland Thaxter, who has published an excellent account of it. It does not, as yet, seem to have spread over a wide area, but it is likely to do so within a few years.

This mildew generally first appears on the sides of the immature pods as a whitish, woolly spot, which, during damp weather, increases rapidly in size. The threads of the fungus penetrate the pod, and may develop on its

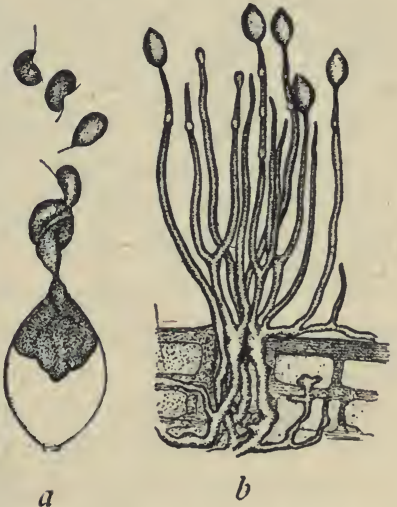

FIG. 56. LIMA BEAN MILDEW. $a$, Spore and zoöspores; $b$, fruiting tuft. Magnified. outer surface until it forms a thick white coating, which often completely envelops the pod. The tissues of pods so affected are, of course, ruined; they shrivel, blacken and decay. A similar injury to the young shoots is often produced, and sometimes the leaves also are affected. 
This mildew is closely related to the Downy Mildew causing potato rot, to which it is similar in life-history and habits. The mycelium develops in the tissues of the bean plant, and usually sends out its fruiting branches through the breathing pores (or stomata). The small oval summer spores are produced upon the tips of these branches, as seen in Fig. 56, b. These spores generally germinate by means of the so-called zoöspores $(a)$, in a way precisely similar to the germination of the potato fungus spores described on Page 8. No winter stage of the fungus is yet known.

Treatment.-All leares, stems and other refuse from the bean plants should be burned as soon after harvest as possible. Experiments in spraying with fungicides have apparently not yet been tried, but the success attending spraying for the related fungus on potatoes indicates that good results are likely to be obtained in this way. The ammoniacal copper carbonate would be a good fungicide for the purpose.

Literature.-The most important account of this disease is that published by Dr. Thaxter in the report of the Connecticut Experiment Station for 1889 (pp. $167-171)$. 


\section{FUNGI AFFECTING THE BEET}

\section{The Beet Rust}

Uromyces betce

In certain portions of the United States the rust of sugar beets has done serious injury. It appears to have originated in Europe ; and in America has been especially destructive in California. Beets attacked by it become dwarfed and discolored.

Professor I. H. Pammel, of the Iowa Experiment Station, has recently published the following account of the life-history of this fungus: "It is characterized by having three stages-the æcidio (cluster-cup) stage, the uredo (red-rust) stage, and the teleuto (winter) stage. 'The first, or cluster-cup stage, occurs on the leaves and stems of seed beets. The cluster-cups contain chains of orange-yellow spores. These germinate under favorable conditions, sending out a little tube, which enters the leaf through its breathing pores. On the inside it develops the mycelium between the leaf cells, sending into the cells themselves small 'suckers,' which absorb their contents. After a time this mycelium produces, in certain places, spores of another kind called the uredo spores, which are pushed out through the skin of the leaf. These spores soon germinate and spread infection to other plants. Late in the season still another kind of spore is found. It is known as the teleuto-spore, or winter-spore. These do not germinate until the following spring, when a tube known as the promycelium is pushed out. This tube is branched, and bears small 
lateral bodies, known as sporidia. These germinate, and when falling on the proper host, produce the xeidium stage, thus completing the eycle of the year."

Treatment.- 'The development of the disease upon seel beets, where alone, according to some authorities, the first stage is passed, may probably be prevented by spraying with some of the copper fungicides-the Bordeaux mixture, for example. The removal and burning of affected leaves is also recommended.

Literature. $-A$ good account of this disease, with figures of the spores, may be found in the United States Department of $\Lambda$ griculture report for $188 \%$ (pp. 350-353). It has also been discussed by Dr. Halsted, in the Bulletin of the Iowa Agrieultural College for 1888; and by Professor Pammel, in Bulletin No. 15 of the Iowa Experiment Station (pp. 235-236).

\section{The Beet Leaf=spot Disease}

\section{Cercospora beticola}

This diseace appears to be more widely prevalent in America than the leaf-rust. It first appears on either the upper or lower surfaces of the leaf, or on both, in the shape of small pale brown, more or less circular spots, with lighter colored margins. At first these spots may be no larger than a pin-head, but they grad.ually increase in size, and often run together and form large discolored patches. As the spots grow older they become darker colored. When the attack is serious much injury may be accomplished in lessening the size of the crop. This disease attacks both the sugar beets and the ordinary varieties of cultivated beets. It has also been found upon various varieties of mangolds.

The affected tissues are shrunken by the action of the fungus. By the aid of a lens one can see, here and there on the diseased surfaces, the long, slender, cylin- 
drical spores projecting outward from the breathing pores, or through ruptures in the skin. Each of these spores is divided by transverse partitions into several distinct cells, and each of these cells is capable of sending out a germinating tube to start the disease in a new place. In autumn these spores fall to the ground with the foliage, and remain there over winter in condition to infect a new crop the following spring.

Treatment.-The last statement in the preceding paragraph indicates the desirability of rotation of crops in preventing this disease. In case the same ground must be used for beets several successive seasons, the leaves should be removed when the crop is gathered, and burned, or composted, and the resulting compost applied to some other crop than beets. If these measures are not sufficiertly successful, it is probable that spraying with the common fungicides will prove an efficient preventive.

Literature.-The most important article concerning this disease yet published in America occurs in Bulletin No. 15 of the Iowa Experiment Station. It is by Professor L. H. Pammel. 


\section{FUNGI AFFECTING THE CABBAGE AND CAULIFLOWER}

\section{The Club Root}

Plasmodiophora brassica

The club-root of cabbage, caulifower, turnip and other cruciferous plants, is well known to most gardeners in the eastern and central States. It is also found in many parts of Europe, having been known in Scotland for more than a century. The disease is sometimes called "clump foot," "club foot," and "fingers and toes ;" it often does great damage, sometimes destroying entire crops. The trouble has been attributed to various causes, but it is now definitely established that the agency chiefly concerned is a low form of fungus-one of the slime-molds-the vegetative portion of which does not even develop mycelium threads, but grows as a semi-liquid slimy mass. This gains access to the tissues of the young roots and develops in the cells, causing the tissues to become malformed in various ways. After developing in this way awhile the mold produces innumerable spores, which are set free by the rotting of the root tissue, and left in the soil. Here they germinate by the production of zoöspores, which remain in the soil apparently indefinitely, and penetrate-when opportunity offers-the thin-walled cells of roots and rootlets, thus continuing the cycle of existence.

The disease commonly attacks seedlings in the seed bed. Such plants begin an abnormal root-development, 
a few roots becoming greatly swollen, as shown in Fig. $5 \%$, and the leaves, instead of having the dark green color of healthy foliage, become pale green or yellowish.

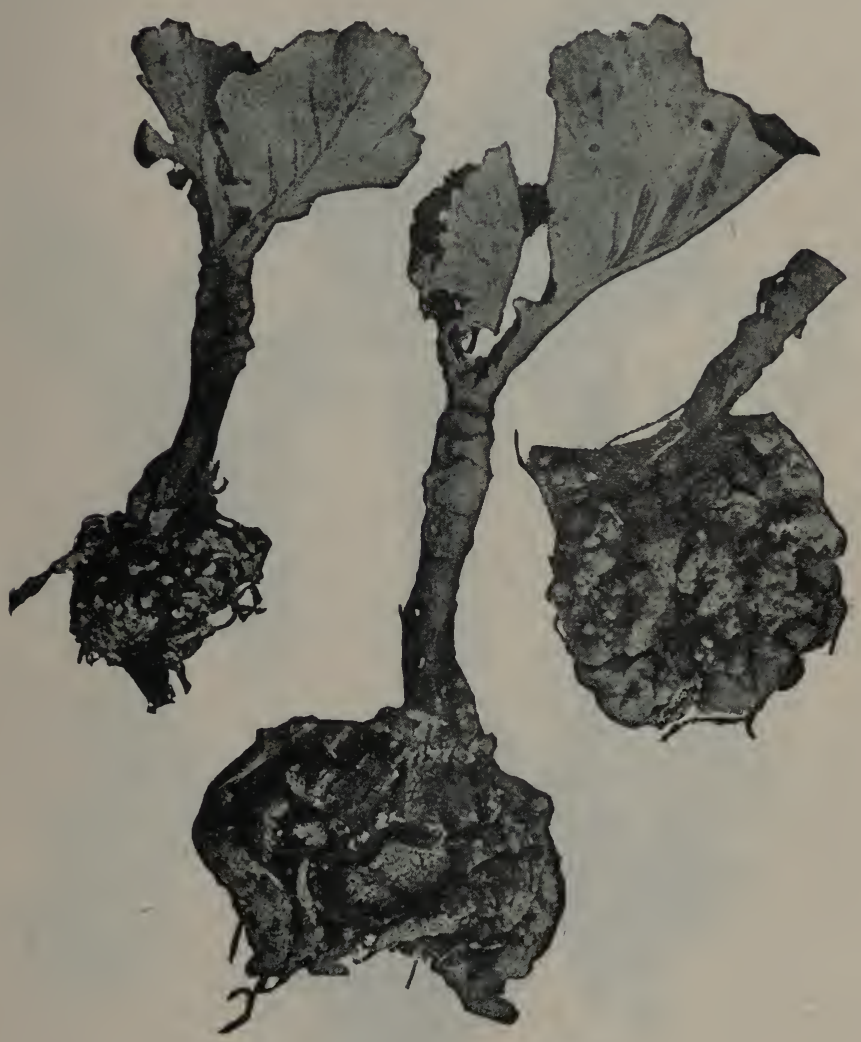

FIG. 57. CLUB ROUT OF CABBAGE.

Such an injury, of course, prevents the proper development of the plant, which becomes worthless.

The injury to other crops than cabbage is often severe. Cauliflower is frequently attacked with fatal, effect, as may be seen in the photo-reproduction in Fig. 
58, while turnips commonly suffer in a most disastrons manner (Fig. 59). But cultivated crops are not the only hosts of the fungus - a fact which makes it still more

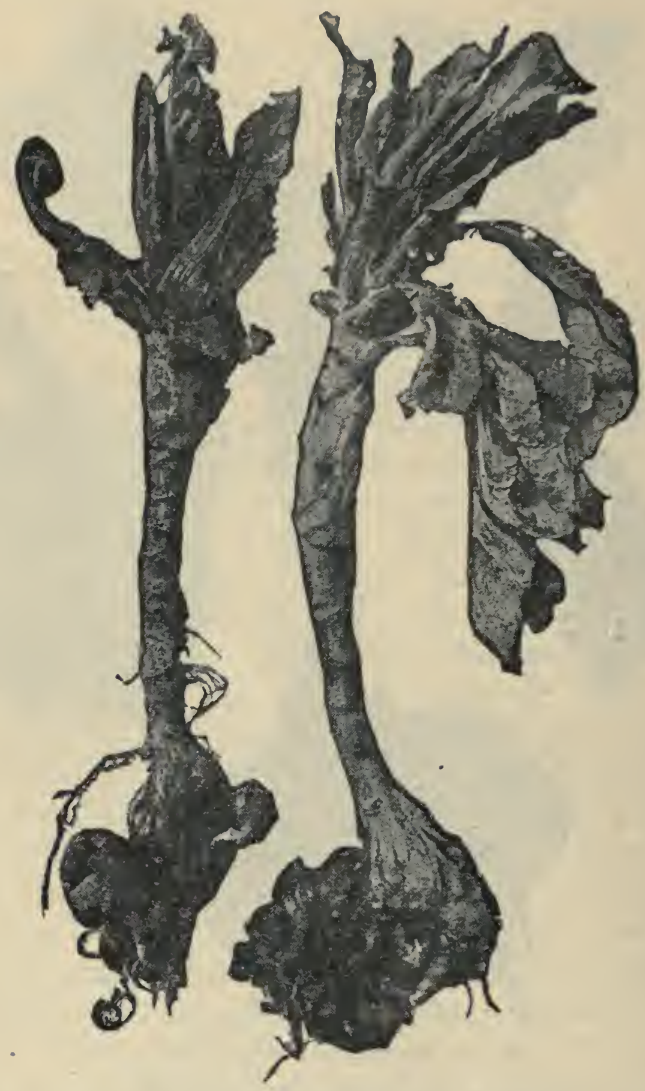

FIG. 58. CLUB ROOT OF CAULIFLOWER.

difficult to contend against. Various weeds belonging to the cruciferous family are also attacked by the club root fungus. Shepherds' purse, for example, is com- 
monly infested, the roots presenting the appearance shown in Fig. 60. Because of this, crop-rotation, which
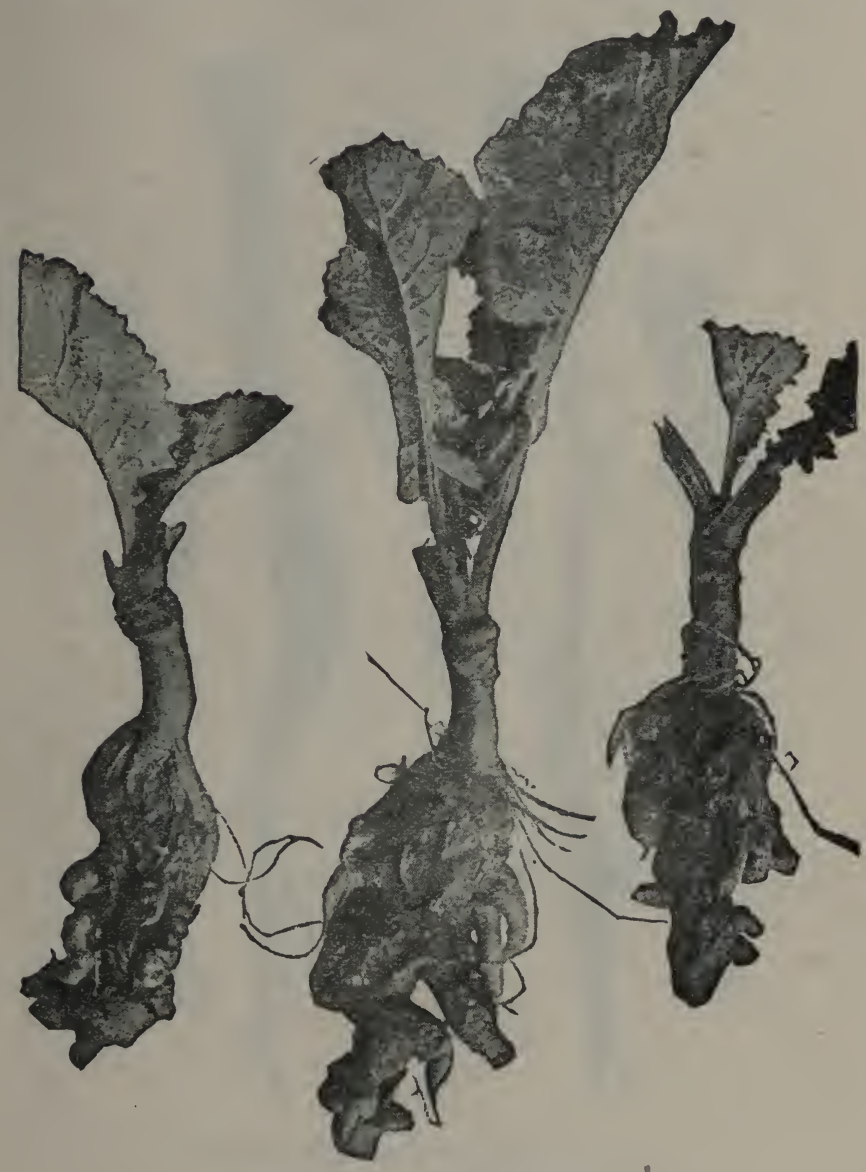

FIG. 59. CLUB IBOOT OF TURNIP.

so often proves serviceable in checking fungous diseases, may possibly become ineffectual; but this is, nererthe- 
less, one of the best preventive methods. Crops on land which has previously been planted to cabbages or turnips are most liable to suffer, but the disease is said

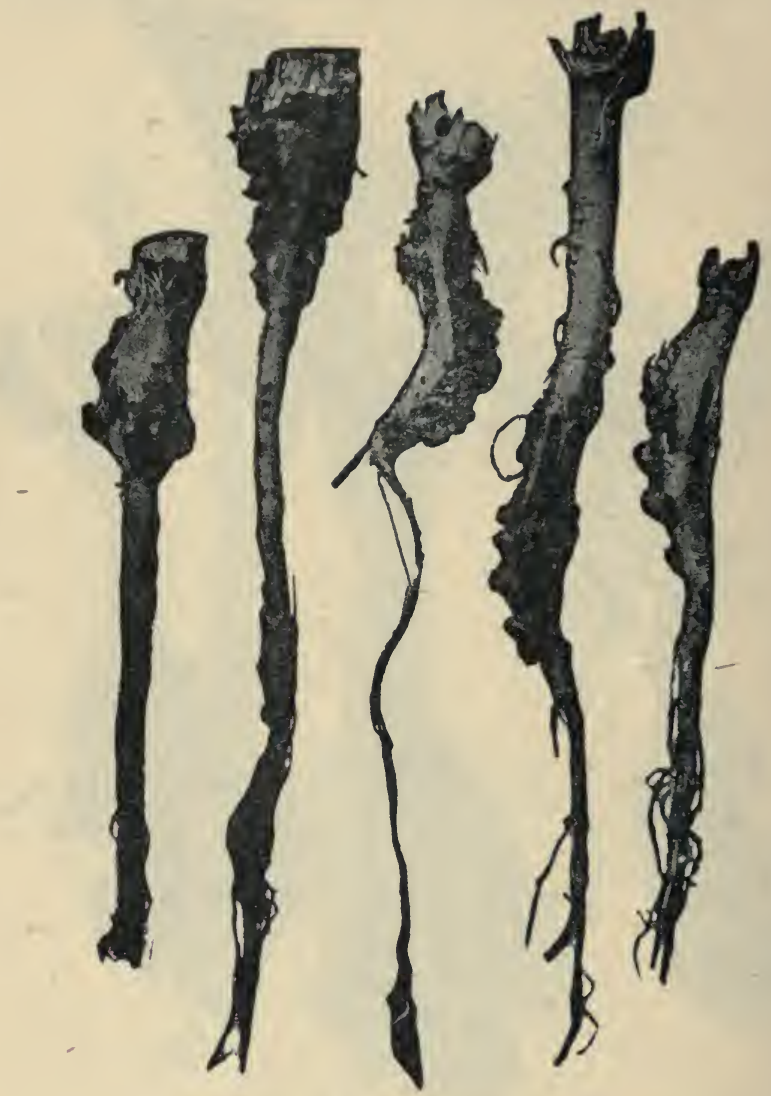

FIG. 60. CLUB ROOT OF SHEPHERD'S PURSE.

sometimes to appear on new land. Crops on limestone soils are usually quite free from attack.

Clean farming, involving the removal and destruction, by burning, of all refuse of the cabbage or turnip 
field, together with constant crop-rotation, are the chief safeguards against the club root fungus. The only way to lessen attack is to use preventive measures; for when once the fungus has obtained a hold upon the plant, it cannot be gotten rid of. It is probable that methods of preventing it from attacking seedlings in the hotbed can readily be found, but few definite experiments on the subject seem yet to have been made in America. English writers assert that if the soil of the seed bed be treated with carbon-bisulphide before the seeds are planted, the traces of the fungus in the soil will be destroyed, and the seedlings escape attack. If many of the seedlings in the seed bed show the disease, the whole lot better be pulled up and burned, and other plants obtained. The use of lime at the rate of seventyfive bushels to the acre, has been recommended as a preventive, and, apparently, backed by practical experience.

Excellent accounts, in which the life-history of this fungus is fully discussed, occur in the Journal of Mycology (v. VII, pp. 79-88), by A. C. Eycleshymer; in Ward's Diseases of Plants; and in Bulletin 98 of the New Jersey Station, in which Dr. Halstead first published the illustrations appearing above. An effect very similar to club root is often produced on the roots of a great variety of plants by the little worms called Nematodes. 


\section{FUNGI AFFECTING CELERY}

\section{The Celery Blight}

\section{Cercospora apii}

The common blight of celery, sometimes incorrectly called the rust. is a destructive and widespread disease, which appears from the middle to the last of summer.

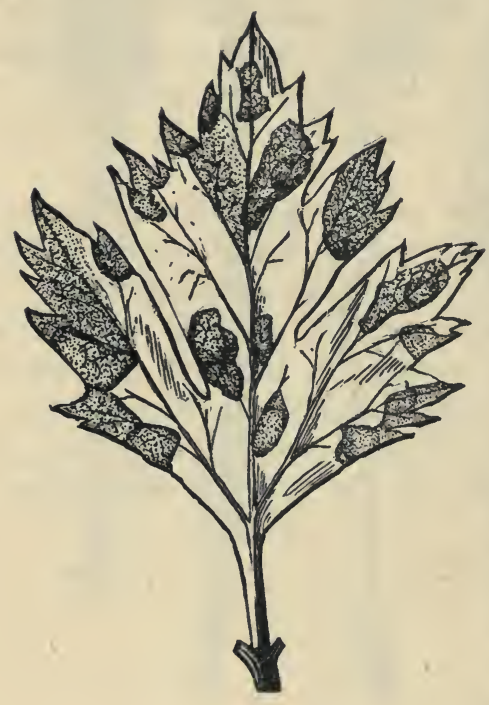

FIG. 61. CELERY LEAF SHOWING BLIGHT.

Its presence is usually first seen in the shape of small, irregular, yellowish-green spots, less than a quarter of an inch in diameter, upon the leaves. These spots increase rapidly in size, and soon change to a brown color. In a short time they so spread as to form great blotches, involving a large portion of the leaf, which may finally wither and die. The fungus causing this disease reproduces by means of elongate spores. When one of these falls upon a moist celery leaf it germinates by sending out a long tube, which penetrates the leaf, and develops the mycelium among the cells. Here it continues growing 144 
for some time; then certain branches of the mycelium are pashed through the breathing pores, or stomata, of the leaf, and produce on their tips the spores. Fig. 62 $b$, represents a sectional view of a leaf having the mycelium developed among the cells, and the spore-producing branches coming out through a breathing pore. In $a$, of the same figure, two spores in process of germina-

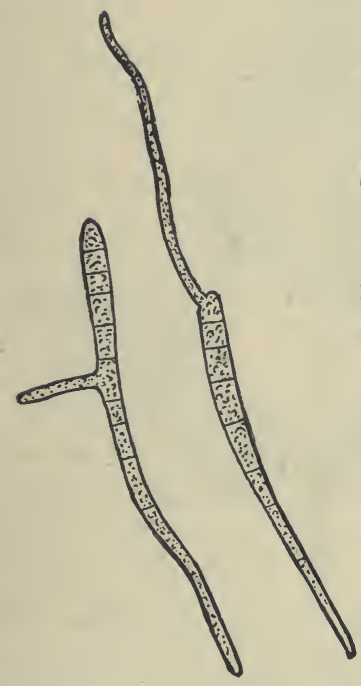

$a$

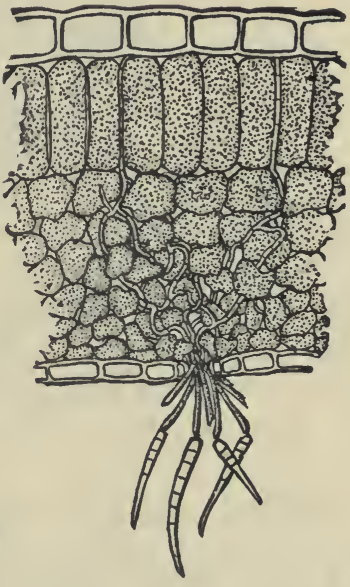

b

FIG. 62. CELEIRY LEAF-SPOT.

$a$, Spores germinating; $b$, section of leaf showing fungus. Magnified.

tion are represented. No winter spores have yet been discovered.

It has been found, in some localities, that celery growing in the shade is seldom affected by this fungus. Hence it is recommended that, unless fungicides are to be employed, as advised below, the celery bed be placed. in situations shaded by trees; or that it be artificially 
shaded by screens of lath, or similar material. It is important, also, that refuse leares affected by the disease be gathered and burned.

Literature.-Articles concerning this fungus occur in the United States Department of Agriculture reports for 1886 (pp. 117-120) and 1888 (pp. 398-399); Bul-

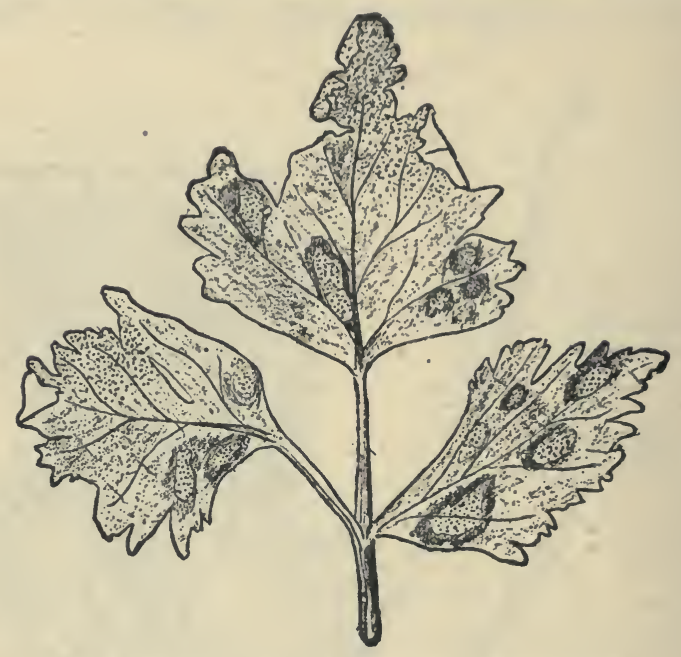

FIG. 63. CELERY LEAF INJURED BY LEAF-BLIGHT.

letin 2, New Jersey Experiment Station, and 1891 report (pp. 250-253) ; also Bulletin No. 51, New York Experiment Station.

\section{The Celery Leaf=blight}

Septoria petroselini, var. apii

This is a disease somewhat similar to the blight already described, which attacks all portions of the celery plant except the root. Its presence is commonly first shown by the appearance, on the leaves or stems, of watery areas, which soon afterwards become spotted 
with small black dots, projecting slightly above the cuticle of the plant. These dots consist of the spores, or reproductive bodies of the fungus. A leaf injured by this malady is represented in Fig. 63. The black spots appear also on the stems and seeds of the fruiting plant, as shown in Plate $\mathrm{XV}$, and it seems probable that the fungus is disseminated by means of stch diseased seeds. The malady commonly appears in the seed-bed, and it is, at least, a safe precaution not to plant seeds so spotted. Those who harvest celery seed should not gather from plants so diseased.

Accounts of this malady occur in report of New Jersey Experiment Station, 1891 (pp. 255-256), and Bulletin 2; report Massachusetts Experiment Station, 18.91 (p. 231) ; and Bulletin No. 51, New York Experiment Station. Still another celery leaf fungus, belonging to the genus Phyllosticta, has been described by Dr. Halsted.

Treatment for Celery Diseases.-The most promising method of preventing these celery diseases is that of spraying the young plants with dilute Bordeaux mixture, beginning soon after they come up in the seedbed, and continuing the treatment at intervals of ten days or two weeks, at least until transplanting time. Later sprayings with either the Bordeaux mixture or the ammoniacal copper carbonate solution, are advisable, if the disease appears in the field. Such sprayings may be made, according to some experiments, up to the time of blanching, without danger of injuring the plants for food, but it would be better, usually, to discontinue the treatment some weeks earlier. Refuse celery should not be left upon the field, especially where the same ground is to be planted to celery the following season. 


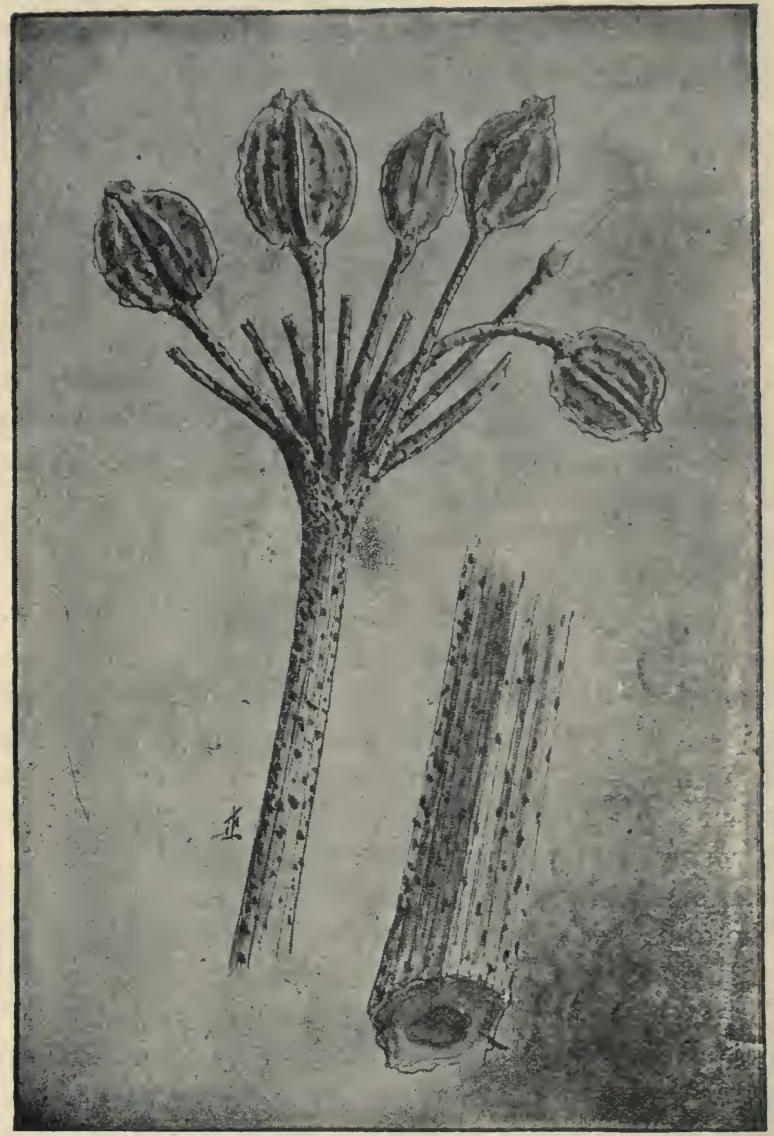

PLATE XV. MAGNIFIED VIEW OF CELERY SEED AND PORTIONS UF STEMS DOTTED WITH FUNGUS OF LEAF-BLIGHT. 


\section{The Soft Rot of Celery}

The central portions of celery plants are frequently attacked by a disease which causes what growers call the

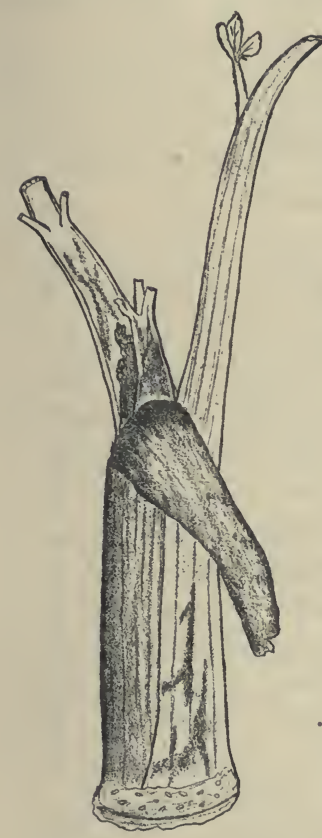

FIG. 64. SOFT ROT OF CELERY. "soft rot." A portion of a plant so affected is represented in Fig. 64. This appears to be due to minute bacteria. It especially attacks plants banked or stored in wet places, and sometimes causes serious losses. Golden sorts appear to be most liable to the malady. Dr. Halsted advises, as a preventive, keeping celery dry or placing it under pure water. His discussion is found in the 1892 report of the Jew Nersey Experiment Station. The injury of this malady is not confined to the core. The leaves are also affected; they become spotted with brown, the spots often having the watery ap-

- pearance that bacterial blights are likely to produce. Instances are on record in which large crops have been ruined by this disease. It seems quite possible that the bacteria cansing this malady are the same as the ones causing tomato and potato blight and similar diseases. 


\section{FUNGI AFFECTING THE ONION}

\section{The Onion Mildew}

Peronospora schleideniana

This disease appears upon the tops of onions as a grayish, moldlike, velrety coating, which is followed by more or less wilting of the affected leaves (Fig. 65).

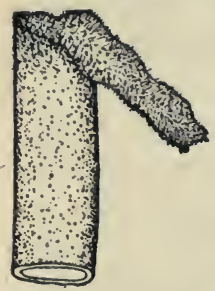

FIG. 65. ONION LEAF AFFECTED

Seed onions seem to be the most liable to injury, and crops grown on low, damp ground, are more subject to attack than those in higher, drier situations. The fungus has been known in Europe as a serious enemy, for many years, but has only been recognized in America for about a decade. 'The threads of the fungus push about between the tissue cells WiTH MILDEW. of the host, destroying their contents and causing the collapse of the leaves. Certain branches are sent out through the breathing pores of the leaf, on which the spores are developed, as shown in Fig. 66 . The spores are pointed-oval in shape, and have a faint purplish tinge; they are easily detached, and wafted or washed from plant to plant by wind or water. Under farorable conditions they quickly germinate, entering the tissues through the breathing pores by means of a short germ-tube. Thus the fungus may spread rapidly.

Besides these conidia, or summer spores, the fungus develops certain winter spores, called oöspores, by means of which it passes the winter. These are produced within the tissues, of the host-plant, and carry 
the fungus over from season to season. They have a thicker wall than the conidia, and are spherical rather than oval.

Treatment.-The destruction, by fire, of all refuse tops in which the resting spores may pass the winter, is one of the most important remedial measures. Such tops should never be turned under unless the ground is to be used for some other crop the following year. Rotation of crnns will probable prove the most success-

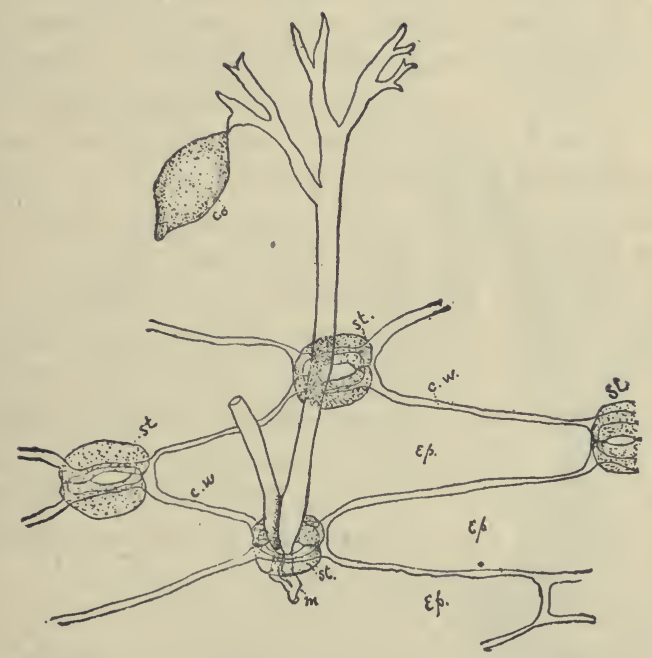

FIG, 66. DEVELOPMENT OF SPORES. MAGNIFIED.

ful general remedy. Where the use of fungicides is practicable these, no doubt, can be employed to good advantage.

Literature.-Professor William Trelease published an excellent account of the onion mildew, in 1883, in the first report of the Wisconsin Experiment Station. Dr. Thaxter also has a good discussion of it in the report of the Connecticut Station for 1889 (pp. 155-158), and. 
Professor Dudley a notice of it in Bulletin 15 of the Cornell Station.

\section{The Onion Smut}

Urocystis cepuloe

The smut of onions has been known to occur in America for about thirty years, although it was not definitely named and described by botanists until $187 \%$ It is widely distributed in the United States east of the Mississippi river, and appears to be especially destructive in the onion-growing regions of Connecticut. Dr. Roland Thaxter, recently mycologist to the experiment station of that State, has carefully studied the disease, publishing an excellent illustrated account of it in his report for 1889, from which the accompanying figures, and much of the following information, are taken.

According to Dr. Thaxter, "the presence of smut in onions is first indicated by one or several dark spots at different heights in the leaves of seedlings, which are seen to be more or less opaque when the plant is held up to the light. These dark appearances may be seen in the first leaf, before the second leaf has begun to develop at all, and are more commonly found just below the "knee;" though they sometimes occur above it. After a time, usually while the second leaf is developing, longitudinal cracks begin to appear on one side of these spots, which widen and show within a dry, fibrous mass, covered with a black, sooty powder made up wholly of the ripened fruit or spores of the fungus, which are blown or washed out onto the ground. In some cases the smut may appear only toward the upper end of the first leaf, and become cnt off from the main body of the plant by the withering of the former. In such a case an onion which has shown smut in its first leaf appears, in some instances, to recover, showing no 
signs of smut in its subsequent growth; but, as a rule, the same dark appearance shows itself in the second leaf and those subsequently formed, and if the seedling is pulled up and examined, the whole plant will be found to be pervaded by the disease, to a greater or less extent. Plants thus diseased, especially if the soil is dry, very commonly succumb early, dying while in the second or third leaf. The stronger plants, however, especially if the ground is moist, are able to resist the smut sufficiently to make a considerable growth, and many survive even up to the time of harvesting. Fig. $6 \%$ represents such an onion reduced to one-third its natural size, and is a typical example of the appearance presented by smutted onions that have survived until midsummer. In such specimens the smut shows itself by black elevations upon the bulb, running down to its very base, and extending up ward into the leaves, the outer of which, in the present instance, have split open, showing the characteristic sooty powder composed of spores mingled with the stringy mass of dead leaf tissue. As a rule such onions always die, either drying up FiG.67. ONION AFFECTED or rotting soon after they are Natural size. pulled." When onions are grown upon the same land for several successive seasons the smut, after it once gets started, gradually increases, until, at the end of five or more years, the soil is so full of smut that the field gen- 
erally must be abandoned and some other crop substituted. But even then the smut remains in the soil several years-according to some observers, as many as twelve-in such a condition that onions cannot be safely planted.

The black powdery masses that develop upon onion leaves affected by smut consist of the spores, or reproductive bodies of the fungus (Fig. $68 a$ ). They are blown or washed into the soil, where, after resting for a period

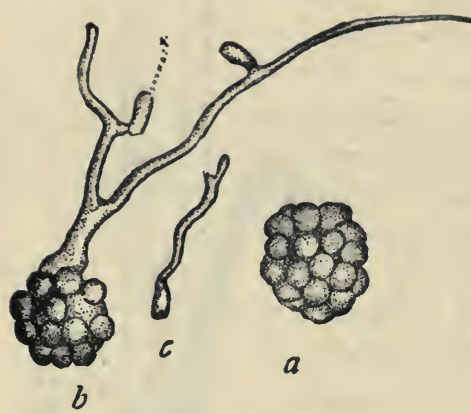

FIG. 68. OxION SMUT.

$a$, Spore; $b$, spore germinating; $c$, sporidia germinating. Magnified.

-sometimes until the following spring, sometimes longer-they germinate by sending out a tube (b), which soon derelops a number of secondary spores, or spo. ridia (Fig. $68 x$ ). These sporidia themselves have the power of germinating, sending out a short tube $(c)$, which enter's the young plant just starting from the seed. This infection apparently occurs before the plant has appeared above ground; and while, as just indicated, it probably is usually due to the germinating sporidia, it is also probable that it is sometimes directly due to spores which do not develop sporidia. After the fungus has once gained access to the young onion plant, the development of mycelium begins, and continues until a new crop of spores is produced.

Local Dissemination.-Dr. Thaxter states that "the local dissemination of smut is due to four principal causes. First, through agricultural implements; plows, harrows, weeders, rakes, etc., which spread the soil containing smut spores, both by scattering the surface earth over a smutted field, and, unless they are thoroughly 
cleaned, by carrying earth containing smut spores into fields subsequently worked upon. Secondly, through the adherence of the same smutted earth to the feet of men and farm animals, and its consequent transportation from one part of a field to another, or to different fields; an agency by no means unimportant. Thirdly, the smut spores may be readily washed, with surface earth, from higher to lower ground, as is a matter of common olsservation. Fourthly, popular opinion to the contrary, the spores being practically imponderable, may be readily blown, with other dust-like material, either about the same field, or into adjoining fields. The reason that this mode of dissemination is of less importance than some others lies, probably, in the fact that the spores being formed and making their exit from the onion comparatively near to the ground, are readily washed into it by rain, and have little opportunity for blowing directly into the air, as is the case with corn smut, for example."

Treatment.-The simplest method of avoiding injury by onion smut is to transfer the planting to new land whenever the disease becomes destructive. But of course this is only applicable either where one grows only a comparatively small number of onions, or has a large amount of land.

It has already been stated that infection by smut apparently takes place before the young plant appears above ground. In the case of corn and other grain crops affected by various species of smut, the fungus enters the plant when very young. These facts would lead us to suppose that if young onions were started in soil free from smut, and then transplanted to smutty soil, they would escape the disease, because the period of infection has been passed. And such is said to be the case with transplanted seedlings. Consequently, in the practice of transplanting onions, - which is highly recommended 
by leading horticulturists for other reasons than this, there is a simple and efficient remedy. Concerning the practical value of transplanting, a word further may be said. Experiments made at the Ohio Experiment Station, by Mr. W. J. Green, indicate that by starting onions in forcing houses or hotbeds the yield may be nearly doubled, without involving any more labor. Concerning the cost of cultivation, Mr. Green says :

"The difference in cost of cultivation was considerable, the ratio being about one to two in favor of the bed of transplanted onions. At the first weeding both beds were weedy, but while the weeds were as large as the onions in the bed where the seed was sown, making weeding difficult and slow, the task was comparatively easy in the other bed. At the second weeding it was necessary to remove many of the small onions in the bed where the seed was sown, an operation which is equivalent to an extra weeding. The work of weeding was but one-half on the bed of transplanted onions that it was ou the other bed. Counting the extra trouble of growing in the greenhouse and transplanting, the work on the two beds was about the same for the whole season; that is, transplanting adds nothing to the cost of growing the crop, aside from the necessity of a greenhouse, hotbed or cold-frame, in any of which the plants can be started.

"The difference in the time of ripening was about one month, in favor of the transplanted onions, making it possible to use them for bunching, and also to market the crop at an earlier date than could be done with those sown in the open' ground. 'The yield of the transplanted onions was about double that of the others."

Experiments by Dr. Thaxter indicate that possibly flowers and sulphur and air-slaked lime mixed together in equal parts, and sowed with the seed, may hare a preventive effect. The same authority says that "all refuse 
of whatever kind that is left on the field should be burned as soon as practicable, and, although onion land is usually kept so clean that it cannot be burned over in the fall, this practice will be found very advantageous when it is possible. At the second and subsequent hand weedings all onions which show smut in the second or third leaf should be pulled, collected in a basket or other convenient receptacle, and burned at once. This practice involves very little trouble, and the folly of leaving the larger smutted onions to discharge crop after crop of spores upon the ground, as the leares successively mature, is apparent; especially when the enormous number of spores thus formed is considered. It is hardly an over-estimate to say that a single large onion may mature during a season something like a cubic inch of smut, which means between one and two thousand millions of spores, each capable of producing a smutty ouion in the following season."

Literature.-Dr. Thaxter's article so freely quoted in the above account, will be found in the report of the Connecticut Agricultural Experiment Station for 1889 (pp. 129-153). It contains numerous references to the European literature of the subject. An earlier article, by Professor W. G. Farlow, will be found in the report of the Massachusetts State Board of Agriculture for 1876-7\% (p. 164).

\section{The Onion Spot Disease}

\section{Vermicularia circinans}

This is a fungus which has been described as injurious to white varietics of onions after they are housed. It starts in the field on part of the bulbs; these produce many spores, by means of which it is propagated in the bins when the conditions are favorable; that is, when the atmosphere of the storage room is warm and moist. 
The disease appears in the field as a blackish growth on the outer bud scales. It is not noticeable at first, and when closely examined will be seen to consist of a central dot or ring, surrounded by larger rings. During damp weather the black growth develops rapidly, sometimes in the form of circles, and sometimes simply spreading without circles, as in Fig. $69 a$. When the dis-

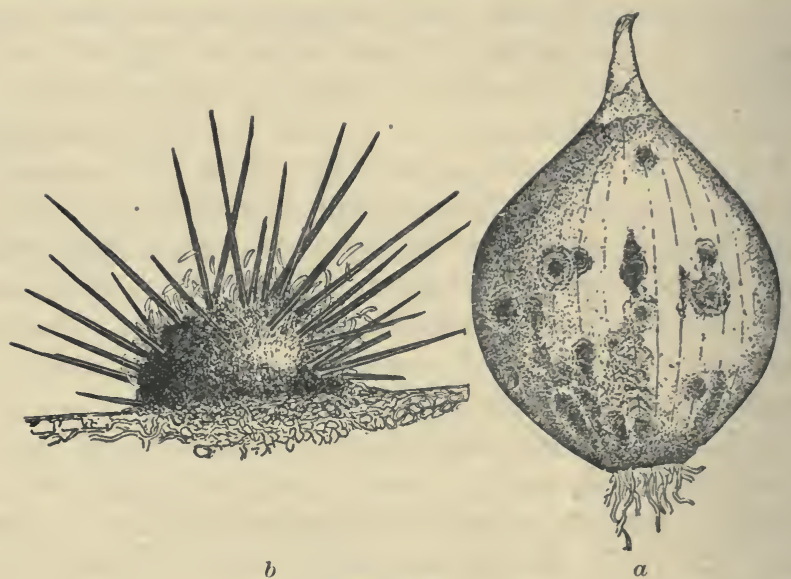

FIG. 69.

$\alpha$, Spot disease of onions; $b$, spores.

ease first appears it only affects the outer scales, but later it penetrates deeper and causes rot.

When highly magnified the black specks on the bulb scales resemble Fig. $69 \mathrm{~b}$. Each consists of a mass of mycelium having long, black, pointed bristles, around the bases of which the small, slightly curved spores are produced in great numbers. These spores are easily blown upon surrounding bulbs, where they may germinate and start the disease again.

Treatment.-One of the best safeguards against this disease is to put dry onions in dry bins, in cool and dry storerooms. The onions should not be allowed to 
heat at all, and bins which have contained diseased onions should be disinfected by spraying or dusting with some fungicide before they are again used. It has been suggested that sprinkling the bulbs with dry, air-slaked lime might prevent the spread of the disease.

1)r. Thaxter's article upon this disease may be found in the report of the Connecticut Experiment Station for 1889 (pp. 163-165).

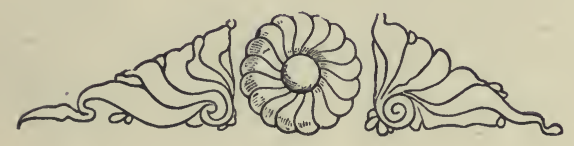




\section{FUNGI AFFECTING MELONS AND CUCUMBERS}

\section{The Cucumber Mildew}

\section{Plasmopara cubensis}

In America this disease has been recognized as a destructive enemy of cucumbers and other cucurbitaceous plants for only three or four years, but it is already widely distributed, and in many places has done much damage. The fungus attacks the leares in a manner somewhat similar to the attack of the downy mildew of the grape. The mycelium, after entering the leaf from a germinating spore, develops between the cells, and sends suckers into the cells to absorb their contents. In due time this mycelium sends branches out through the breathing pores of the leaf, on the tips of which are produced the spores. The injured leares turn yellowish or brown in spots, and if the attack is severe, are finally destroyed.

The destruction of all refuse leaves that may have been infested, and spraying with fungicides, are the best remedial measures. A rather full account of the fungus may be found in the eighth report of the Massachusetts Experiment Station (pp. 210-212; 1890), and in American Gardening, April, 1893.

\section{The Bacterial Blight}

This disease has been especially troublesome in the Southern States, where it has done much damage to the melon crop. It is also destructive in the truck-growing 
regions of the North, and it is possible that it is due to the same germs as the bacterial blights and rots of various other vegetables, such as celery, potato, tomato, etc. "Soon after the plants are up, and usually by the time they have reached out a foot or so upon the ground, the trouble begins. The stem may become moist, in a man-

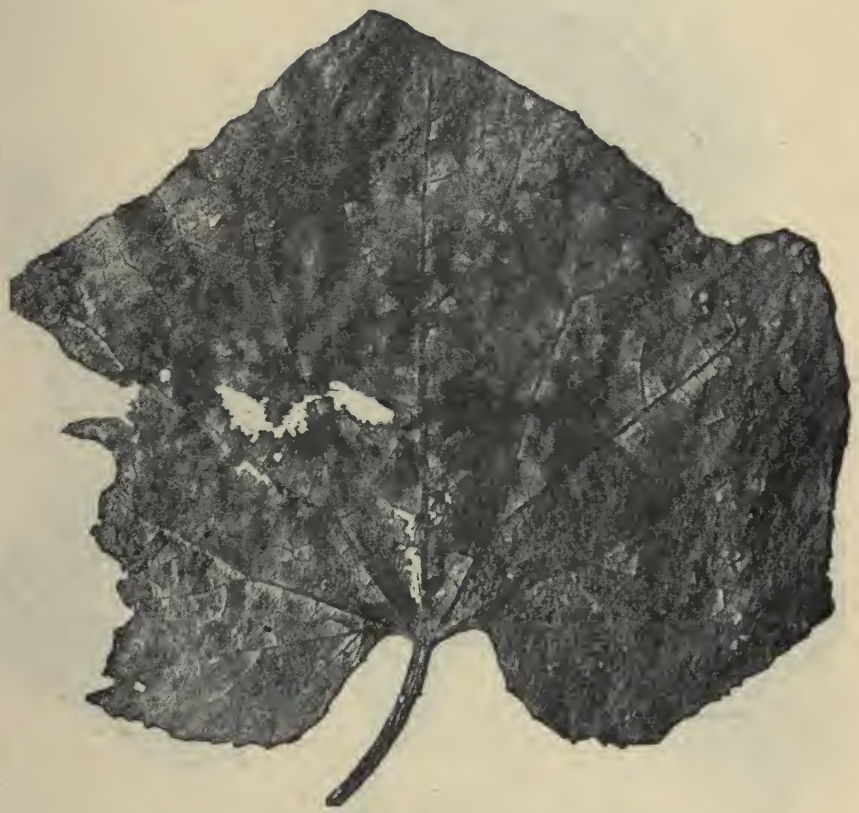

FIG. 70. CUCUMBEI LEAF AFFECTED WITH MILDEW.

ner to suggest what is termed 'water core' in apples. This may be close to the base of the plant, or midway between that point and the tip of the vine. Sometimes one leaf-stalk decays first, and the disease spreads from it to other parts. Occasionally the free young end melts away with the trouble: When tissue that is freshly diseased is examined, it is found swarming with bacteria, 
and no other cause for the disorganization is to be seen. Not unfrequently the leaves become spotted-that is, certain areas decay and fall away. If a leaf freshly affected is held toward the light, the diseased places may be easily detected, by the peculiar discoloration,

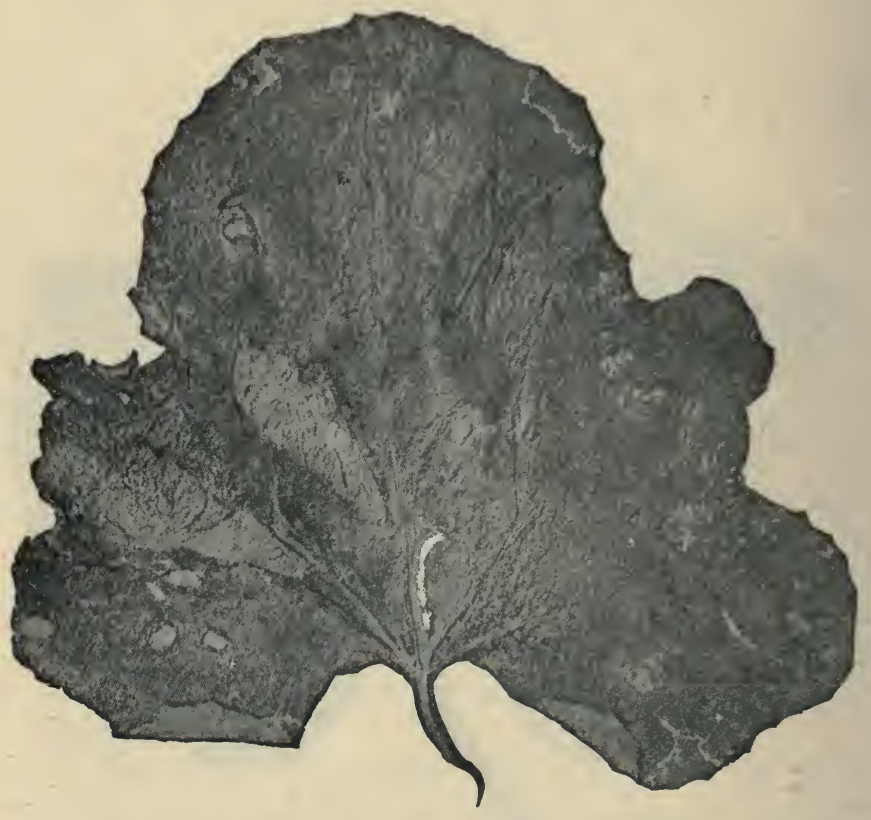

FIG. 71. MUSKMELON LEAF SHOWLYG BACTERIAL BLIGHT.

being due to the excess of moisture-a sogginess, so to speak." (Halsted.)

Effective preventive measures for this vexatious malady have yet to be found. Presumably rotation of crops will prove an important method, but if the same germs affect many widely separated plants, a specially devised rotation may be required. 


\section{The Melon Leaf=spot}

A muskmelon leaf injured by a fungus belonging to the genus Phyllosticta, is represented in Fig. 72. It causes light colored spots, which may eventually break

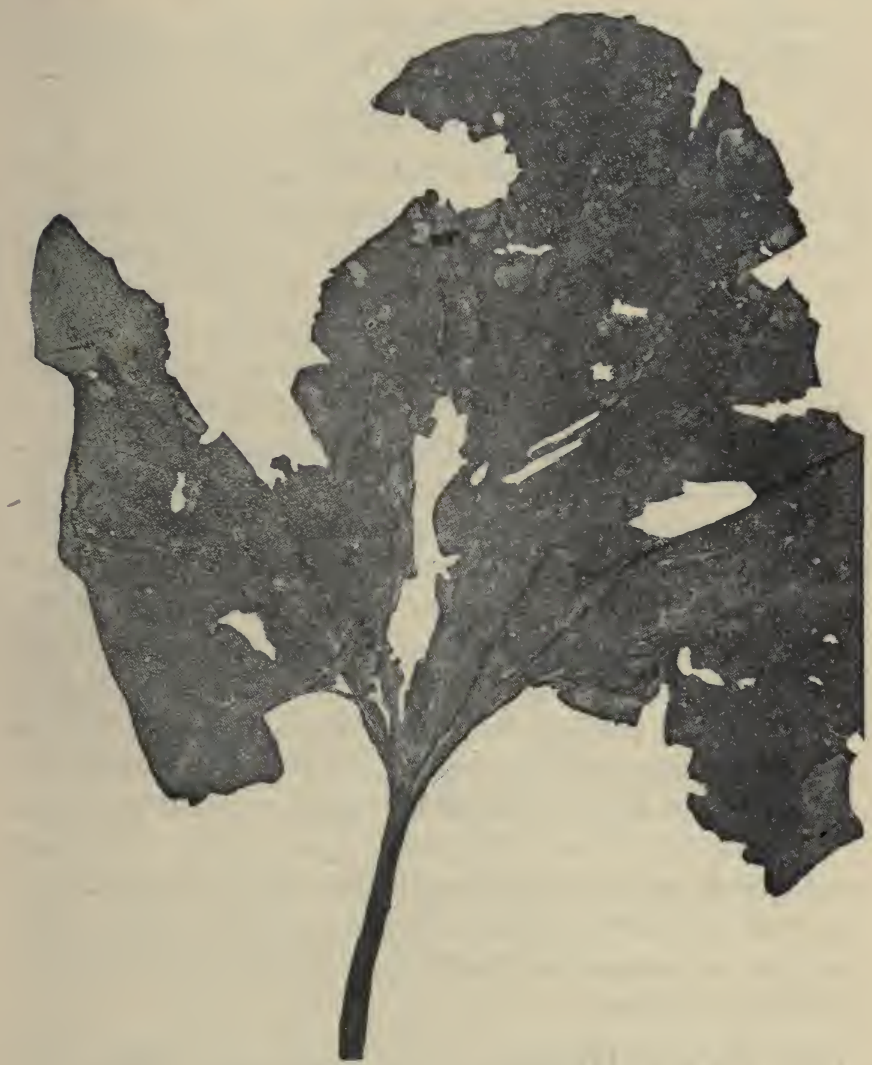

FIG. 72. MELON LEAF-SPOT DESEASE.

away and give the leaf a very ragged appearance. The fungus reproduces by means of small spores, which are developed in great abundance. Presumably spraying with fungicides will have a preventive effect. 


\section{FUNGI AFFECTING THE POTATO}

\section{The Downy Mildew, or Late Blight}

\section{Phytophora infestans}

A sufficiently full account of this disease has already been given in the Introduction (pp. $C-10) . \quad \Lambda$ large proportion of the potato maladies in the United States have, until lately, been attributed to this fungus; but recent observations indicate that other agencies are at workparticularly the fungus known as Macrosporium soluni, and apparently certain bacteria. The dowry mildew disease has been called, by Professor Jones, of Vermont, the "late blight," to distinguish it from the "early blight," caused by the Macrosporium. The late blight fungus generally appearis rather late in the season; and is attack is frequently sudden and fatal, affected plants being entirely destroyed in a few days. 'The tubers are also commonly affected, rotting and producing, during the process, a foul smell. This disease is most destructive during warm, moist weather, at such times spreading very rapidly. It commonly begins as a single spot on a leaf, from which it spreads throughout the plant, sad produces on the lower leaf-surface a mildew-like growth, to be distinguished by the naked eye. This discase can be prevented by spraying several times with the Bordeaux mixture.

\section{The Early Blight, or Leaf=spot Disease}

Macrosporium solani

This disease appears early in summer in the shape of small brown, brittle spots, scattered over the leaf. 
Careful inspection shows that their upper surfaces are more or less roughened by darker areas rising above the dead gray tissue. The spots gradually enlarge, and finally run together to form large brown patches, the intermediate tissues becoming yellowish or sickly green in color. The entire plant finally withers, and dies long before the proper period, the tubers being small-generally less than half full size. But the tubers do not rot and are of good quality. This fungus has proven difficult to study in the field, the spores being produced only on part of the affected plants. It winters over in the spore stage on the dead vines.

\section{The Bacterial Blight}

Besides the two maladies already discussed, there is a potato disease due to bacteria, although it is probable that the Macrosporium blight has frequently been attributed to these organisms. Bacteria often develop in tissues invaded by the fungus just named; but there are good reasons for believing that a genuine bacterial trouble frequently develops in all parts of the plant. It generally starts from the seed planted, which becomes rotten. The vines die prematurely, often wilting rather suddenly, and the young tubers decay. This disease is more troublesome in southern latitudes than at the north.

Treatment of Potato Diseases.-A large $11 n m-$ ber of experiments in many sections of the United States have shown that these various maladies may be prerented by spraying with the Bordeaux mixture. It has been repeatedly shown that vines thus sprayed remained in a healthy normal condition long after the untreated vines were dead, and that, consequently, the tubers developed to a much larger size, with a greatly increased yield. The results of an experiment of this kind, at 


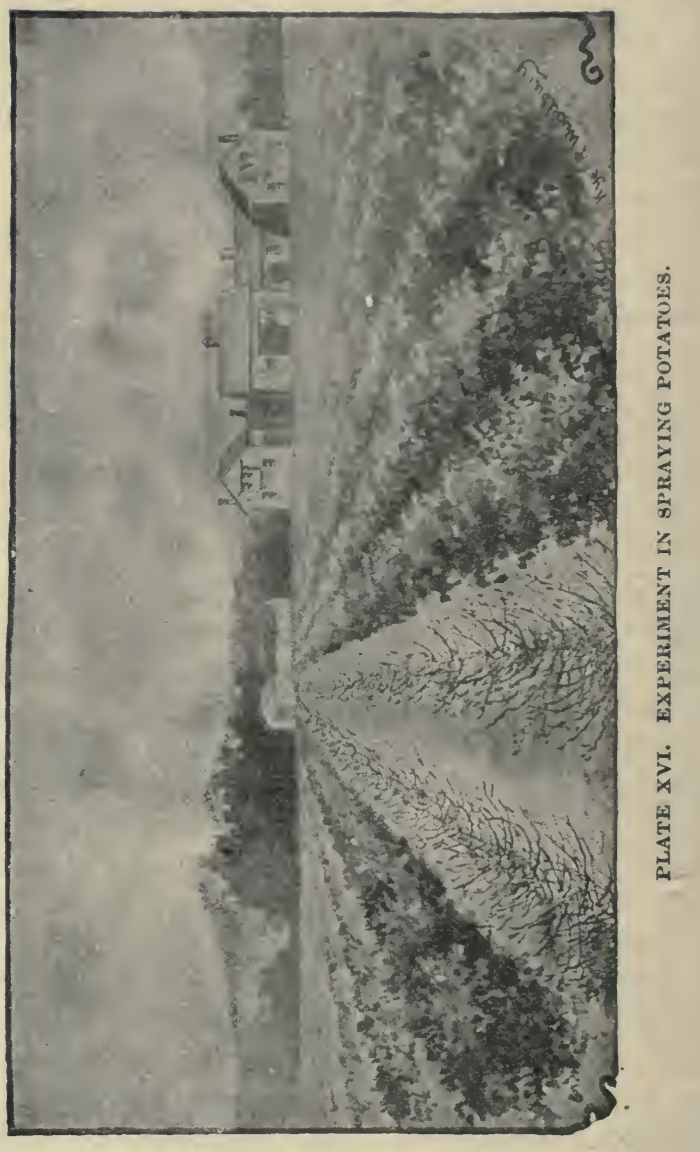


the Rhode Island Station, are shown in Plate XVI, which is reproduced from a photograph taken August 20th. "The two rows in the center of the figure were not treated with the mixture, consequently the leaves all blighted and withered up soon after August 1st, leaving only the bare, dead stems when the photograph was taken; while the leaves and vines in the rows on either side, which had been sprayed with the Bordeaux mixture, were fresh and green."

The effect upon the tubers, of treatment with Bordeanx mixture, as it resulted in some experiments by Professor Jones, of Vermont, is shown in Fig. 73. The
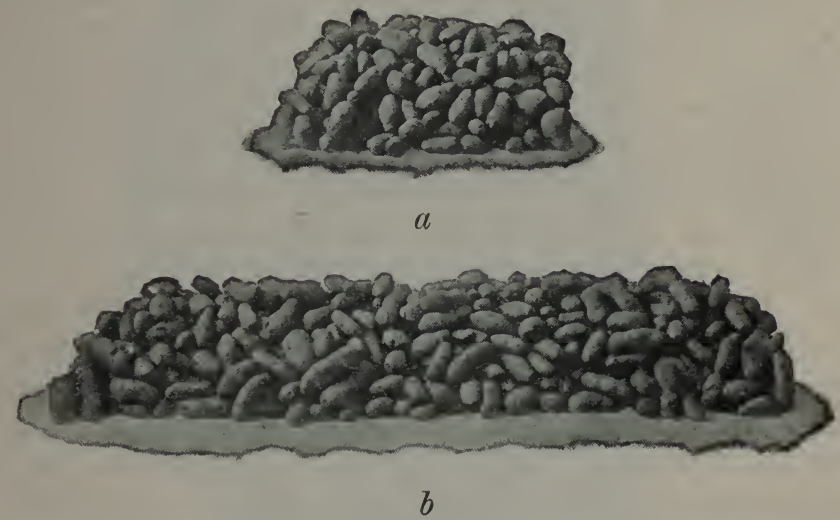

FIG. 73 .

$a$, Yield of unsprayed plot; $b$, of sprayed plot.

treated vines yielded marketable tubers st the rate of two hundred and ninety-one bushels per acre, while those untreated yielded only at the rate of ninety-nine and one-half bushels per acre.

As a general rule, the first application of Bordeaux mixture may be made when the vines are about one-third grown, or earlier if signs of disease appear. Repeat the application when it is washed off-in about a fortnight 
usually. Add half a pound of London purple or Paris green to each barrel of the mixture whenever the Uolorado beetles threateri injury.

\section{The Potato Scab}

\section{Oospora scabies}

The "scab" of potatoes is familiar to every experienced farmer. Like the pear blight, the theories concerning its cause have been many and varied; but the recent inrestigations of Messrs. Thaxter and Bolley have established, with considerable certainty, that the injury is really due to the attacks of a low form of fungus life, which develops in the tissues of the growing tubers. Two forms of saab, the "deep scab" and the "surface scab," have been recognized by some writers, but there is a strong probability that these are simply different phases of the same injury. $\Lambda \mathrm{t}$ any rate, there is little difference, from a practical standpoint, and they will not be separately discussed here.

It has often been noticed that scabby potatoes are more abundant in fields heavily fertilized by barnyard manure. This is now believed to be largely due to the fact that if scabby potatoes are fed to stock, the spores of the fungus can pass through the alimentary canal uninjured, and can multiply abundantly in the manure heap. Consequently they will be transferred to the fieid, and when the potato tubers are developing, will attack them and produce the injury.

The fungus-producing scab is an obscure one, which botanists have studied only recently. It can generally be seen on partially dereloped scabby potatoes, in the shape of fine white threads running over the surface. It reproduces by means of spores. Repeated experiments have shown that if scabby potatoes are planted, a large percentage of the resulting crop will be scabby. 
Professor II. L. Bolley has shown that what is probably this same disease occurs also on beets planted on potato ground.

Treatment.-Dr. Roland Thaxter, after several years of careful study, summarizes the preventive measures to be taken against this disease as follows:

(1) The

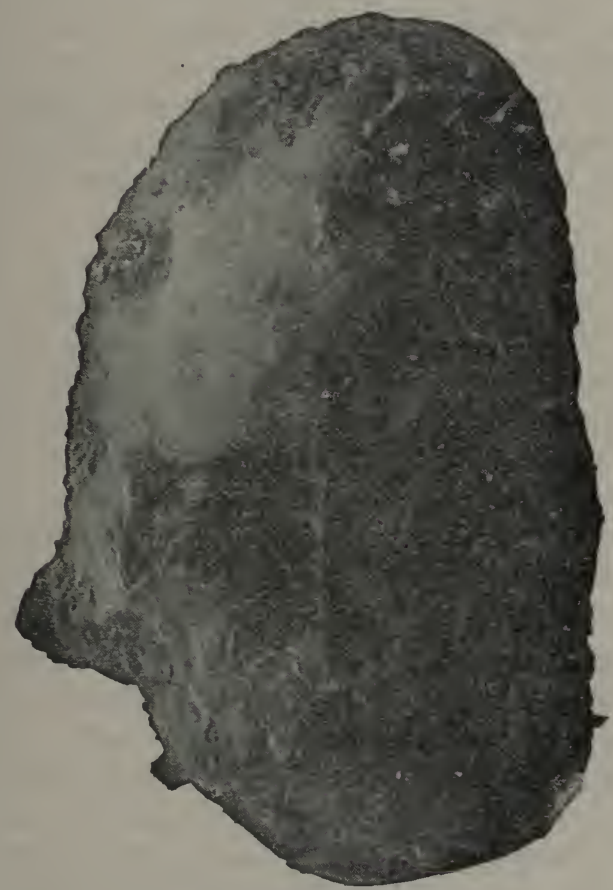

FIG. 74. POTATO INJURED BY SCAB.

secd must be free from any scabs. (2) Land which has produced scabbed crops in previous years, either of potatocs or of beets, or has been fertilized with manure from scab-fed stock, must not be planted to potatoes. Scub potatoes should never be fed to stock, under any 
circumstances, unless they have been thoroughly cooked, even if the land on which the manure is to be used is not to be cropped with potatoes at once. (4) In general, any fertilizer is to be preferred to barnyard manure for potatoes, whether the stock has been fed with diseased potatoes or not. (5) If it is suspected that a crop is scabbed, it is of great importance to dig the potatoes as soon as possible after they are mature, since the scal spots increase in size, and deepen, as long as they are left in the ground, and what is at first a comparatirely slight surface injury may be sufficiently extended to render tubers worthless, which would otherwise have been marketable.

Experiments at the North Dakota Station, by Professor Bolley, show that the disease may be prevented by soaking the seed in a weak solution of corrosive sublimate. Concerning its use, he says: "One wishing to try the corrosive sublimate treatment, if to no greater extent than to assure the raising of healthy, smooth potatoes sufficient for seed the following year, will find it best to proceed about as follows: Procure an ordinary barrel, and fit into the base a common woorlen fancet. Purchase of a druggist two ounces of finely pulverized corrosive sublimate (Mercuric bichloricle). Impty this all into two gallons of hot water, and allow it to stand over night, or until, apparently, all dissolved. Place in the barrel thirteen gallons of water, then pour in the two gallon solution. Allow this solution to stand in the barrel four or five hours, during which time it is several times thoroughly agitated, to insure equality of solution before using. Select as fair seed potatoes as possible, wash off all the old dirt, and immerse as many as you can or wish to treat at one time in the solution one hour and thirty minutes. At the end of this time turn off the solution into another ressel. The same solution may thus be used a number of times, if wished. 
After drying, the potatoes may be cut and planted as usual. Plant upon ground that bas not previously borne the disease. 'The potatoes may be cut before treatment if wished.

"Caution:-The corrosive sublimate is a strong poison, and too great care cannot be exercised in its use. The strength of the solution as here reconmended, one part in one thousand, is the same as that used in surgery, and is not such as to work injury unless taken into the stomach. Great care should be taken in handling the pure substance, and all treated potatoes should be planted. Thie solution should not be placed in metallic vessels."

This method has been tried by Mr. T. B. Terry, the well-known Ohio specialist, and endorsed. The potatoes may be conveniently dipped in the solution if they are first placed in coarse sacks, like coffee sacks, through which the liquid readily passes. Mr. W. J. Green, of the Ohio Experiment Station, has r'cently announced that excellent results in scab prevention were obtained by soaking the seed for one hour in dilute Bordeaux mixture.

Literature.-Dr. Roland Thaxter's articles on the subject are found in the reports of the Connecticut Experiment Station for 1890 and 1891, and Professor Bolley's contributions in Agricultural Science, Vol. IV, and Bulletins Nos. 4 and 9 of the North Dakota Experiment Station. Other articles may be found in the 6th, 7th and 8th reports of the Massachusetts Experiment Station, and in various other reports, bulletins and periodicals. 


\section{FUNGI AFFECTING THE SWEET POTATO}

\section{The Black Rot}

Ceratocystis fimbriata

There are several kinds of "rot" affecting the sweet potato, which have been carefully studied by Dr. Byron D. Halsted, of the New Jersey Experiment Station. 'T'o his studies we are indebted for much of the following information upon the subject:

According to Messrs. Halsted and Fairchild, "the most conspicuous sign of the present disease, and the one which distinguishes it from other diseases, occurs upon the potatoes themselres. It consists in the presence of dark, somewhat greenish spots, varying from a quarter of an inch to four inches in diameter, sometimes covering the greater part of the root and extending some distance into the tissue. These spots, when once seen, can not be mistaken, as they are simply sunken areas with distinct margins, like spots burned into the potato with a metal die, which has left the skin uninjured. Should the slightest doubt as to the identity of the disease remain, after a superficial examination, the removal of a small portion of the skin, exposing the olive-green tissue below, would dispel it. Among the sprouts, or young plants grown in hotbeds, the disease manifests itself in dark lines upon the lower portion of the shoot, and sometimes of the lower leares, giving rise to the name of "black shank" amung the growers. These dark lines or blotches often appear upon etiolated portions of the stem, and are almost black in color. In very severe cases the tip of the sprout wilts and dies. 
No appearance in the field has so far been observed, that would distinguish hills diseased with black rot from those attacked by some other of the numerous rots; but the dark sunken areas on the potato, and the black discolorations of the sprouts, can scarcely be confused with any other sweet potato disease."

This black rot has been found seriously injurious in New Jersey, Maryland, Delaware and Virginia, and it probably occurs in many other portions of the United States. It frequently destroys twenty-fire per cent. of the crop, the injury taking place mostly after the potatoes are stored, when the fungus can easily pass from root to root.

A microscopic examination of portions of diseased roots shows the presence of threads of mycelium, which push about between and through the cells, absoribing the starchy matter with which the latter are normally filled. These mycelial threads have thick walls, and are olive-brown in color. Under suitable conditions of warmth and moisture, they produce on the outside of the skin of affected root or stem numerous spores (called conidia) of two distinct forms; and there are also formed within the substance of the potato certain flaskshaped bodies, within which are produced a third kind of spores. The disease is likely to start from affected potatoes planted in hotbeds to obtain sprouts. The mycelium may pass directly from the root to the young sprout, or the latter may be inoculated by means of spores. Such sprouts, when planted, produce diseased roots.

Treatment.-The following preventive measures are recommended by Messrs. Halsted and Fairchild :

1. The first and most important precaution to be taken, in combating the disease, is to plant only perfectly healthy seed in the hotbed, even if it is necessary to import such. This preventive measure is most essen- 
tial, as diseased seed will give diseased sprouts, which, in turn, will grow a crop of worthless potatoes.

2. The selection of healthy sprouts is plainly necessary, in case the fungus gets into the hotbeds, and under no circumstances should diseased plants be put into the field. 'The test of using copper fungicides in the hotbed has not been made, but, from analogy, seems to promise assistance. If the fungicide is used the shoots should be kept green with it until pulled.

3. Fields which have become so impregnated by the disease that they refuse to grow profitable crops, had best be added to the regular farm rotation. This method will, if continued for several years, allow the accumulated infective material to burn itself out by consuming all available food material in the soil.

4. Decaying roots and the refuse after digging should be carefully removed from the field and burned, as such débris adds to the food of the parasite.

5 . The use of large quantities of barnyard manure probably favors the development of the trouble, since it adds greatly to the decaying vegetable matter of the soil. Where the use of commercial fertilizers can be made to take the place of manure, it will certainly be desirable to make the change.

6. Although no experiments have yet been cornpleted upon the matter, it is probable the spread of the disease in the bin may be checked by dipping the roots in one of the copper mixtures, preferably the ammoniacal solution, before storing for the winter. What effect tobacco smoke, or the fumes of sulphur, would have in checking the disease in the bins remains to be ascertained.

Literature.-The two most important articles concerning this disease that have come to the writer's notice are, first, one by Dr. Halsted, published in 1890, in Bulletin 76 of the New Jersey Experiment Station (pp. 7-14); and, second, one by Dr. Halsted and Mr. D. G. 
Fairchild, consisting of an admirable resumé of the studies of these gentlemen, which appeared in 1891 in the Journal of Mycology (v. VII, pp. 1-11). The reader desiring information concerning the spores and spore formation of the fungus should consult this article. A discussion of the various other diseases of the sweet potato will be found in Bulletin 76 of the New Jersey Experiment Station.

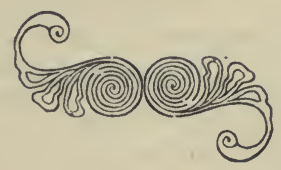




\section{FUNGI AFFECTING THE SPINACH}

\section{The Spinach Mildew}

\section{Peronospora effusa}

Spinach, when forced for market under glass, is subject to attack by several fungous diseases, which have

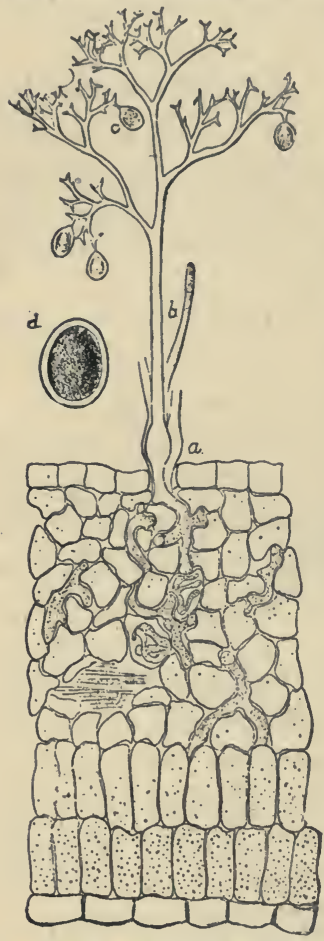

FIG 75. SPINACF MTLDEW.

Section of leaf showing mycellum and development of spore. Magnified. been investigated by Dr. B. D. Halsted. The mildew is one of the most destructive of these maladics. It is closely related to the downy mildew of the potato, and produces "gray, slightly violet, patches if a relvety texture, upon the under side of the leaves, while from the upper side they have a pale yellow shade, due to the loss of the green color." If a cross section of the leaf be made through one of these patches, and is minute piece placed under the microscope on a glass slide, the fungus will be seen to have a structure similar to Fig. $\% 5$, which represents on the lower part the cells of the leaf having the mycelium of the fungus running between some of them, sending here and there "suckers" into the cells themselves to absorb their contents, and pushing out through the breathing pore, $a$, the fruiting stalk, $b$, which bears the spores, $c$. At $d$ one of the spores is shown. more magnified. These spores are scattered to other plants, where they germinatc 
by sending out slender tubes, which may enter the leares through the breathing pores.

\section{The Spinach Anthracnose}

\section{Colletotrichum spinacece}

This is, perhaps, the most destructive of the spinach diseases, as it grows rapidly, and, in consequence, soon spreads over many plants. "The first indication of its presence," writes Dr. Halsted, "is an indescribable moist appearance of the usually circular affected

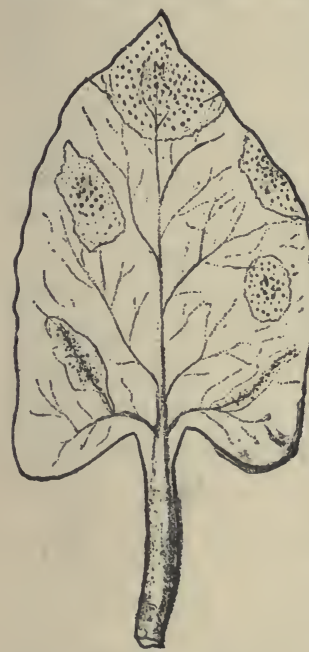

FIG. 76. SPINACH LEAF AFFECTED BY ANTHRACNOSE. part; followed by the appearance of minute brown pustules, while at the same time a gray color develops and the diseased area becomes dry. The anthracnose is shown in Fig. 76, where an affected leaf, much reduced in size, is seen, with some portions killed by the fungus. No particular part of the leaf is first attacked, and, therefore, no two leaves appear alike. In some cases the largest leaves will be diseased, in other plants only the younger ones; but sooner or later plants that are affected will become entirely unfit for use. To test the rapidity of the growth of the anthracnose, healthy plants, grown in the laboratory, were inoculated with the spores, and in from fire to seven days the spots sown liad become thoroughly diseased, and were bearing multitudes of spores." Spinach is also subject to attack by a leaf-blight, a white smut and a black mold disease.

Treatment for Spinach Diseases.-As already stated, the diseases discussed above affect most severely 
spinach forced under glass for early market. That grown out of doors is not infested to nearly so great an extent. As it is impracticable to treat the spinach plants with the ordinary copper fungicides, except, possibly, when very young, such cultural methods must be adopted as will reduce the chances of infection to a minimum. These methods include the collecting and burning of refuse leaves affected by any of the diseases, and the changing of the location of the beds used for spinach each year, if possible ; and if not, the changing of the soil instead. Dr. Halsted suggests raking a mixture of equal parts of air-slaked lime and sulphur into the soil-a measure that is well worth trying. The florist paints his heating pipes with a sulphur mixture, to keep the air of the greenhouse saturated with sulphur fumes, in order to prevent mildew, and it seems possible that the air in hotbeds might also be more or less saturated with such fumes to prevent fungous diseases.

Literature.-The only important general account of these spinach diseases so far published in America is to be found in Bulletin No. 70 of the New Jersey Experiment Station. It is by Dr. B. D. Halsted, and to it the present writer is indebted for the figures and information given above. 


\section{FUNGI AFFECTING THE TOMATO}

\section{The Tomato Rot}

\section{Macrosporium tomato}

The common tomato rot is often extremely destructive, both in field culture and under glass. It usually first becomes noticeable when the fruit is about half grown, appearing at the blossom end as a small blackish spot, that increases in size as the tomato develops. The tissues beneath the spot are destroyed by the fungus, so that the fruit becomes flattened on top, and the inside of the tomato is blackened. The fungus may finally involve the whole fruit, producing a shrivelling and blackening, that is only too familiar to most experienced gardeners. An excellent account of this fungus, by Mr. B. 'T. Galloway, may be found in the 1888 report of the (Tnited States Department of Agriculture (pp. 339-346.)

Treatment.-Professor L. H. Bailey, than whom no American has more thoroughly studied the tomato, says that this rot "can be kept in check by spraying with Bordeaux mixture or ammoniacal carbonate of copper; but it is difficult to apply the material to untrained plants, especially upon rich soil, where they make a thick growth. Plants which are trained to stakes and pruncd admit of thorough treatment. The rot appears to be less, as a rule, if the plants are so trained that the fruits and vines dry off quickly after rains and dews. In single-stem training out of doors, rot was greatly reduced this year. Straw placed underneath vines appears to increase the tendency to rot, and the same 
appears to be true of heavy dressings of stable manure. The less improved varieties of tomatoes, like many of the old angular sorts, and the cherry and plum varieties, are almost exempt from attack."

\section{The Winter Blight}

Professor Bailey has described, under the name of Winter Blight, a malady of greenhouse tomatoes that sometimes proves disastrous to attempts to force this fruit. It has the general appearance of a bacterial blight, although no definite proof has yet been made that it is caused by bacteria. When first attacked the leaves become dwarfed and somewhat faded, with indistinct yellowish spots on the surface. "The spots grow larger, until they often become an eighth of an inch across, or even more, and they are finally more or less translucent. This injury to the foliage causes the plants to dwindle, and the stems become small and hard. Fruit production is lessened, or if the disease appears before the flowers are formed, no fruit whatever may set. In two or three instances in which young plants were attacked, the disease killed the plant outright; but a diseased plant ordinarily lives thronghout the winter, a constant disappointment to its owner, but always inspiring the vain hope that greater age or better care may overcome the difficulty." This blight has not been observed to attack the fruit. As stated above, it appears to be due to bacteria-a species of micrococcus-but is different from the tomato blight of the Southern States. Various remedies have been tried without success, and the best preventive measures are those of the immediate destruction of all blighted plants, and the use of new soil in the greenhouse each fall.

\section{The Bacterial Tomato Blight}

Tomatoes in the Southern States are commonly affected by a blight similar to, if not identical with, the 
bacterial blight of potatoes. The tissues of diseased plants teem with bacterial germs, and no other form of fungus is present at first. 'The malady has been studied by Dr. B. D. Halsted, who has published a preliminary account of it in Bulletin No. 19 of the Mississippi Experiment Station. The presence of the disease is usually shown by the wilting of the younger leaves, especially those at the ends of the stems, and the yellowing of the older foliage. The stems themselves also become affected, and when closely examined, are seen to have numerous watery spots. A longitudinal section of such

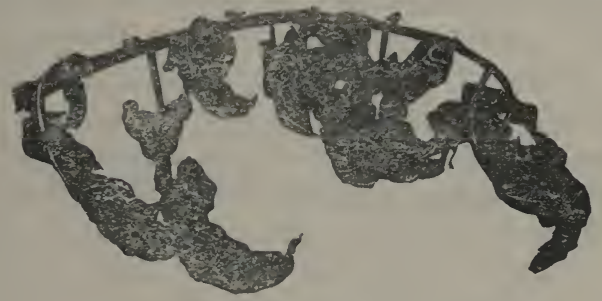

FIG. 77. TILIGHTEN TOMATO LEAVES.

a stalk reveals a greenish, watery center, very different from that of the healthy plant.

There is a blight affecting squashes and melons that seems to be the same disease as this, and also as the potato blight already referred to. Consequently neither of these crops shonld follow the other on the same land, in case the disease has appeared. It is believed that the soil becomes so contaminated with the germs that, in case either of these crops follows the other, the injury may appear again. In addition to proper rotations, the burning of all diseased plants and rubbish in the field, and spraving early with Bordeaux mixture, are recommended as remedial measures. 


\section{FUNGI AFFECTING SEEDLINGS AND CUTTINGS}

\section{The Damping=off Fungus}

\section{Pythium DeBaryanum}

The malady known as "damping-off" is familiar to all experienced gardeners. It affects the seedlings and cuttings of a great variety of plants in the propagating bed. It appears oftenest when the soil surface is damp, the temperature high and the sky clouded. "Its first appearance is indicated by a slight paleness and drooping of the seedlings. If these be carefully remored, it will be seen that the root, either throughout its length, or in portions, is beginning to shrink and decay, and that the root hairs are destroyed. Later, if the plant is not vigorous enough to resist tre fungus and to put forth secondary roots, the disorganization of the tissue extends to the stem, resulting ultimately in the toppling over of the plant and its thorough decay, although, in some instances, the plant remains green for some days after falling. This extends from one plant to another, until only a few or none of the seedlings in a bed may be left."* The plants attacked and the soil between them becomes more or less covered with the mildew-like growth of the fungus mycelium. Recent inrestigations indicate that the fungus gains entrance to the plants through the roots.

Treatment.-According to Mr. T. W. Galloway, of Harvard University, the fungus may be destroyed by

*T. W. Galloway. 
giving the soil the conditions (heat and moisture) favorable to the germination of the spores, and then, a few days later, exposing it thoroughly to a very dry, hot atmosphere, so as to kill the delicate growth of the fungus. It seems likely that the trouble might be avoided by watering the plants with an extremely dilute solution of copper sulphate-say a pound to two hundred gallons. The preventive measures recommended by gardeners, are the avoidance of a high temperature and moist atmosphere, keeping plants stocky, giving plenty of air, and changing the soil frequently.

Literature.-A discussion concerning damping off may be found in the American Garden for June, 1890 (XI, 347-350); also in H. Marshall Ward's Diseases of Plants; and in the Transactions of the Massachusetts Horticultural Society for 1891. The latter contains the article by $\mathrm{Mr}$. Galloway from which the above quotations were made.

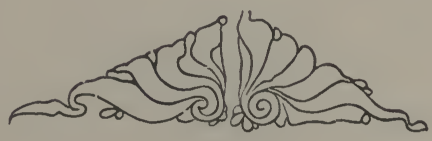




\section{PART V}

FUNGI AFFECTING CEREAL AND FORAGE CROPS 


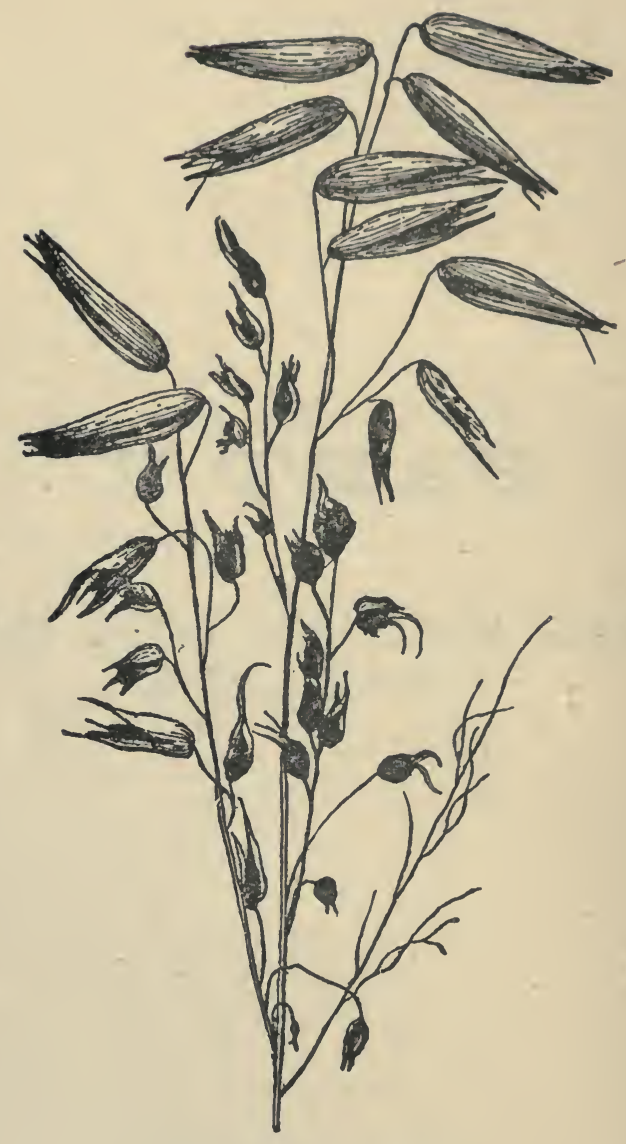

PLATE XVII. OATS SMUT. 


\section{FUNGI AFFECTING OATS}

\section{The Loose Smut}

\section{Ustilago avence}

Some estimates of the loss due to this fungus have already been given in the Introduction (p. 2). A good representation of its appearance is seen in Plate XVII. The black masses consist of millions of minute spores, by means of which the fungus reproduces itself. The spore masses ripen about the time the oats are in bloom, when the chaff enveloping the embryo seed is spread wide open. The spores are blown over the field, and many of them lodge on the inner side of the chaff particles, where they remain as the seed ripens, and are not dislodged when it goes through the threshing machine. The smut spores are also largely distributed from the smutted heads and lodged in the chaff of sound kernels during threshing, although it is probable that only a small percentage of them get far enough into the chaff to infect the plants that develop from the kernels.

After the spores have lodged in the chaff they remain there until the oats are planted. Then they germinate by sending out little tubes, which enter the young plant through the first leaf-sheath. These tubes are only able to gain access to the plants during a very short period of the growth of the latter. After the oats have pushed out the second leaf the danger of infection by smut is past. When the germinating tube has entered the plant it sends out branches in all directions, penetrating the stem and all its parts, thus forming the 
mycelium, or vegetative portion of the fungus. As the oats plant grows this mycelium also develops, taking possession of all the new tissues of the host, and forming within the head a mass of thick threads. These threads eventually produce vast numbers of spores, so using themselves up in the operation that they become gelatinous, and finally altogether disappear, leaving

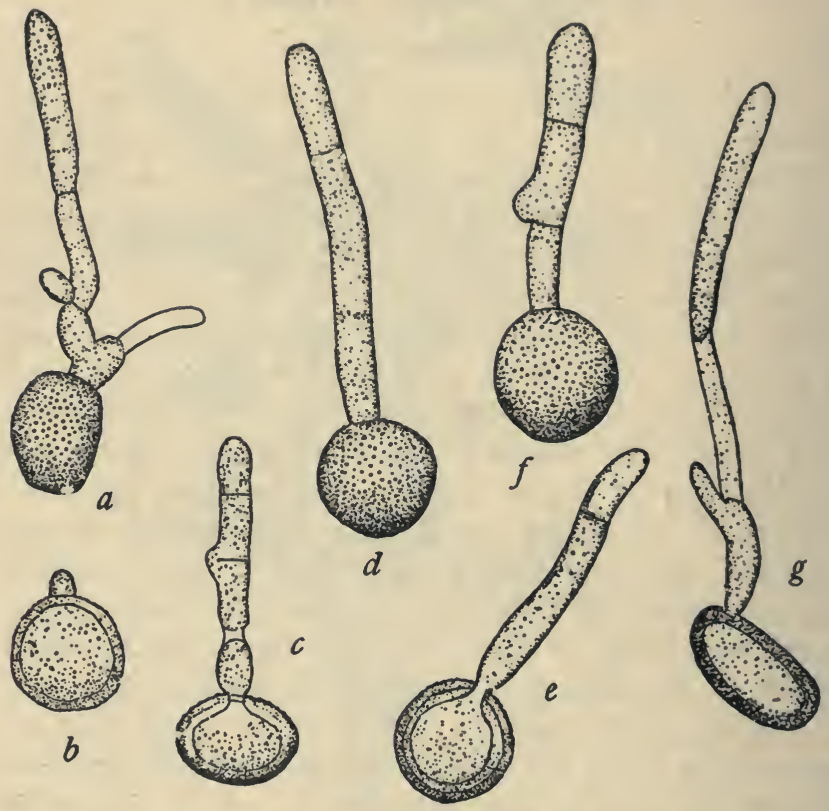

FIG. 78. SMUT SPORES GERMINATING. MAGNIFIED.

nothing but the powdery mass of spores, which are blown about to infect other plants, and thus begin anew the cycle of existence.

The smut mycelium usually produces no peculiar effect upon its host-plant early in the season. Infested plants are seldom distinguishable from healthy ones 
until it is nearly time for the oats to blossom. Then comes a sudden change; the spores develop rapidly, and are dry, powdery masses before the plants are through blooming. When one of the branches of a stooling plant is infested, the others from the same root usually are also, a result of the entrance of the smut so soon after the seed germinates. It sometimes happens that only a part of the spikelets of a head are attacked, and, according to Kellerman and Swingle, "in a few cases smutted heads have been collected where the smut has destroyed the grain and flowering glumes, while the large outer husks are yet entirely sound. Such a head would scarcely be seen to be smutted unless carefully examined." Most of the best authorities agree that there is very little danger of infecting oats with smut from the spores in barnyard manure applied to the soil. The mycelium of the oat smut fungus is composed of extremely delicate threads, and the spores are very minute, ranging from one-five thousandth to one-three thousandth of an inch in diameter. They are oval, or sub-globose in shape, with the outside wall spiny, or warty, having minute elevations all over its surface. One side is lighter colored than the other. In water or in a nutrient solution these spores germinate readily, as seen in Fig. 78, the germinating tube appearing on the light side of the spore. As these tubes grow, cross partitions $(c, d, e, f$,$) frequently appear, and sometimes the$ peculiar little cells called sporidia are dereloped $(a)$. These sporidia might be called temporary spores, because if placed in a nutrient solution, or manure water, they grow something as spores do. Some authors have claimed that on account of their presence in manure applied to the land, oats may be infected with smut, but this is disputed by Jensen and others. When massed together the spores are of a dark, dusky brown color, but when separated and viewed with the microscope 
they are clearer and lighter, though still brown. Professor Kellerman estimates that a compact cubic inch of smut would contain $64,000,000,000$ spores.

Treatment.-In 188\%, Professor J. I. Jensen, of Denmark, announced that the smut of oats and wheat can be prevented by soaking the seed for five or ten min-

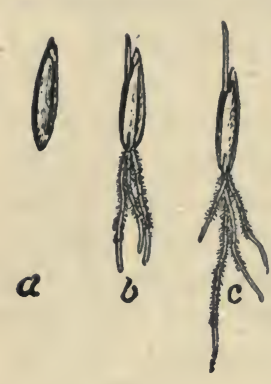

FIG. 79. OATS GERMINATING. utes in water heated to $133^{\circ} \mathrm{F}$., without injury to the germinating qualities of the seed. Further experiments in Europe by the same investigator, and in America by several experimenters-notably Kellerman and Swingle in Kansas, and Arthur in Indiana-have abundantly justified these claims, and have demonstrated that by this simple treatment agriculturists can prevent, practically, all of the loss now suffered from this disease. And, strangely enough, these experiments have shown that the treatment indicated not only prevents the smut, but that it also hastens the germination of the seed and increases the yield, above that which the prevention of the smut accourits for, to such an extent that it would pay to treat it were no smut present. The hastening of germination has been well represented by Professor Arthur, in Fig. 79, showing oats that have been in a germinator three days; $a$, having been previously soaked in a solution of copper sulphate; $b$, having had no treatment; and $c$, having been soaked in hot water. It will at once be seen that the hot water has hastened the germination, and that the copper sulphate has retarded it. In Fig. 80 are represented the same kernels after they had been growing two weeks on moist blotting paper; $d$ is the one treated with copper sulphate; $e$ the one untreated; and $f$ the one soaked in hot water. As will be noticed in the engraving, the 
relative growth of the three plants is practically the same as it was after the seeds were three days in the germinator.

In Kansas Professor Kellerman made a special series of experiments, which showed that there was an increase

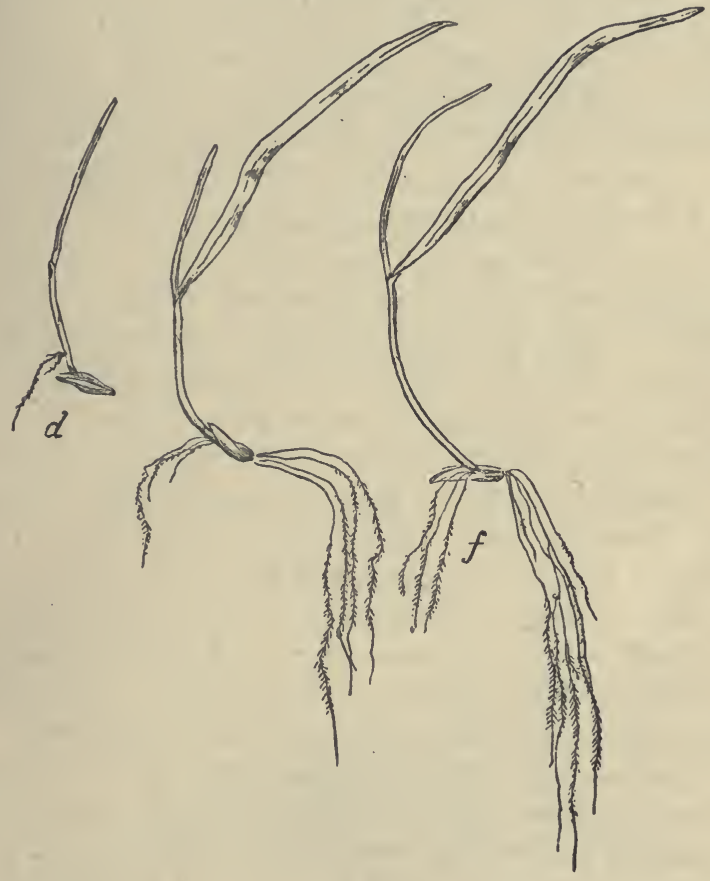

FIG. 80. OATS PLANTS TWO WEEKS OLD. ONE-HALF NATURAL SIZE.

of from four to eight bushels per acre over that accounted for by the mere prevention of the smut, when the seed was treated with hot water.

Professor Arthur has shown that the oats may be treated with hot water long before the time of planting, with as good results, both as to prevention of smut and increase in yield, as when treated just before planting. 
The following method of treatment with hot water has been recommended, as adapted to the facilities of most farmers. Have ready for the work some coffee sacks, two ordinary wash-tubs, a good supply of hut water and a clean barn floor. Partially fill tub No. 1 with water heated to about $130^{\circ} \mathrm{F}$., and tub No. 2 with water at $140^{\circ} \mathrm{F}$. Then fill the coffee sacks with the oats to be treated, and, taking one sack at a time, immerse it a minute or two in tub No. 1, for the purpose of partially heating the oats; then lift it up, let it drain for a moment, and then dip it in tub No. 2, leaving it there for from five to eight minutes, turning and kncading the sack to get all the seed soaked. Then empty the oats on an airy floor-if possible, in the sunshine or a draft of wind, and on a dry day-and let them become thoroughly dry. A supply of hot water should be kept on hand, some of which is to be poured into the tubs at frequent intervals to replenish the supply and keep up the temperature, which must be determined often by a good thermometer. In tub No. 2 the water should never get above $145^{\circ}$, nor below $133^{\circ}$

For a long time solutions of copper sulphate have been used to prevent grain smut, but in the light of our better knowledge they should be discarded. 'They retard the germination of the seed and decrease the yield.

Experiments at the Kansas Station, by Professor. Kellerman, show that oat smut may also be prevented by soaking the seed for twelve hours in a solution of one pound of potassium sulphide (liver of sulphur) to ten gallons of water. "Place the seed in a wooden vessel, and pour on the solution until the seed is covered several inches deep. Stir the solution before pouring on the grain, and thoroughly mix the seed several times before taking the latter out of the solution.

Then spread out to dry. It will probably be best to sow the seed as soon as possible, and before it becomes thor- 
oughly dry." The hot water treatment, however, is probably the better one.

Literature.-An account of Professor Jensen's experiments may be found in the Journal of the Royal Agricultural Society of Englind (v. 24, part II, 1888). The following publications also contain accounts of this disease: Kansas Experiment Station, Bulletins 15, 22 ; report for 1889, pp. 213-288; Indiana Experiment Station, Bulletin 35; North Dakota Experiment Station, Bulletin No. 1; United States Department of Agriculture, Farmer's Bulletin No. 5.

\section{The Oats Rust}

The rust of oats is essentially the same as that of wheat, being caused by the same fungi, and the account given on Pages 200-201 will suffice for this.

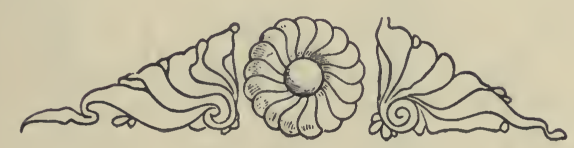




\section{FUNGI AFFECTING WHEAT}

\section{The Bunt or Stinking Smut}

Tilletia foetens

This is the most destructive smut affecting wheat. It differs from the loose smuts in that the individual kernels are affected, instead of the whole head. According to Professor Arthur, wheat plants injured by this disease "thrive about as usual, the head fills and the chaff is distended, as if with normally plump grain. A close observer will notice, however, that already before wheat heads out the diseased plants have a darker green color and somewhat more luxuriant appearance. When the grain is only six inches high or so, this difference in appearance is quite striking, the affected plants being darker green and taller, as if droppings of manure had forced them to extra growth. The growth does not continue so long, however, as in the healthy plants, so that they do not usually become so tall, and are premature in heading and ripening up the leaves. The characteristics now become rather more evident. The affected heads retain a bluish-green, or greenish-lead color, for some time after the sound ones begin to ripen, and then take on a bleached appearance, in strong contrast to the yellow of the sound heads; the heads being much lighter stand more erect, and the chaff and beard are more open and spreading (Fig. 81)." If the injured kernels are broken open they are found to contain a solid mass of black powder-the spores of the fungus.

The life-history of this fungus does not differ essentially from that of the loose smut of oats already discussed (pp. 18\%-193). 
Treatment.- This smut may be prevented by the hot water treatment mentioned in connection with oat smut. Mr. W. T. Swingle gives the following directions for treating seed wheat:

"Provide two large ressels-as two kettles over a fire, or boilers on a cook stove-the first containing warm
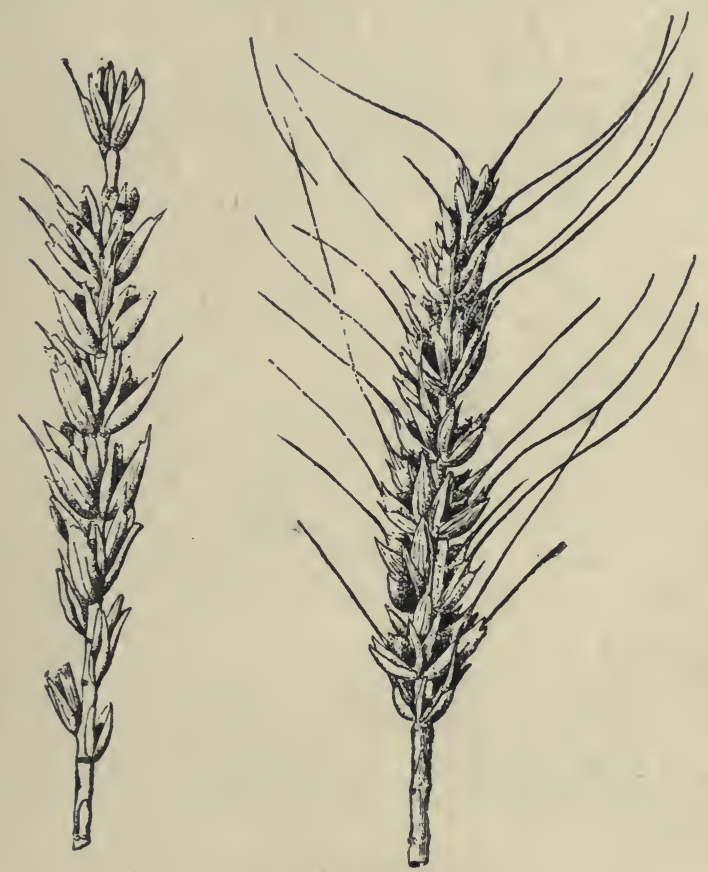

FIG. 81. WHEAT BUNT.

water (say $110^{\circ}$ to $130^{\circ}$ ) and second containing scalding water $\left(132 \frac{1}{2}^{\circ}\right)$.

"The first is for the purpose of warming the seed, preparatory to dipping it into the second. Unless this precaution is taken, it will be difficult to keep the water in the second vessel at a proper temperature. 
"The seed which is to be treated must be placed, a half bushel or more at a time, in a closed ressel, that will allow free entrance and exit of water on all sides. For this purpose a bushel basket made of heary wire could be used, with which spread wire netting, say twelve meshes to the inch, or an iron frame could be made at a trifling cost, over which the wire netting could be stretched. This would allow the water to pass freely, and yet prevent the passage of the seed. A sack made of loosely woven material (as gunny sack) could, perhaps, be used instead of the wire basket. A perforated tin ressel is, in some respects, preferable to any of the above.

"Now dip the basket of seed in the first ressel; after a moment lift it; and, when the water has for the most part escaped, plunge it into the water again, repeating the operation several times. The object of the lifting and plunging, to which should be added also a rotary motion, is to bring every grain in contact with the hot water. Less than a minute is required for this preparatory treatment, after which plunge the basket of seed into the second ressel. If the thermometer indicates that the temperature of the water is falling, pour in hot water until it is elevated to $132 \frac{1}{2}^{\circ}$. If it should rise higher than $135^{\circ}$, add small quantities of cold water. This will doubtless be the most simple method of keeping the proper temperature, and requires only the addition of two small ressels, one for cold and one for boiling water.

"Steam, conducted into the second vessel by a pipe provided with a stopcock, answers even better, both for heating the water and elevating the temperature from time to time.

"The basket of seed should, very shortly after its immersion, be lifted, and then plunged and agitated in the manner described above; and the operation should be repeated eight or ten times during the immerșion, 
which should be continued fifteen minutes. In this way every portion of the seed will be subjected to the action of the scalding water. Immediately after its removal dash cold water over it or plunge it into a vessel of cold water, and then spread out to dry. Another portion can be treated similarly, and so on until all the seed has been disinfected. Before thoroughly dry the seed can be sown ; but it may be thoroughly dried and stored if desired.

"The important precantions to be taken are as follows: (1) Maintain the proper temperature of the water $\left(132 \frac{1}{2}^{\circ} \mathrm{F}\right.$.), in no case allowing it to rise higher than $135^{\circ}$, or to fall below $130^{\circ}$. This will not be difficult to do if a reliable thermometer is used, and hot or cold water be dipped into the vessel as the falling or rising temperature demands. Immersion fifteen minutes will not then injure the seed. (2) See that the volume of scalding water is much greater (at least six or eight times) than that of the seed treated at any one time. (3) Never fill the basket or sack containing the seed entirely full, but always leave room for the grain to move about freely. (4) Leave the seed in the second ressel of water fifteen minutes."

Literature.-This smut has been very often treated of during recent years. Articles concerning it may be found as follows: Bulletin No. 1, North Dakota Experiment Station; Bulletin No. 28, Indiana Experiment Station; Bulletins and reports Kansas Experiment Station, 1890-1891. 


\section{The Loose Smut}

\section{Ustilago tritici}

The loose smut of wheat is at once distinguished from the bunt by the fact that the spores are not con-

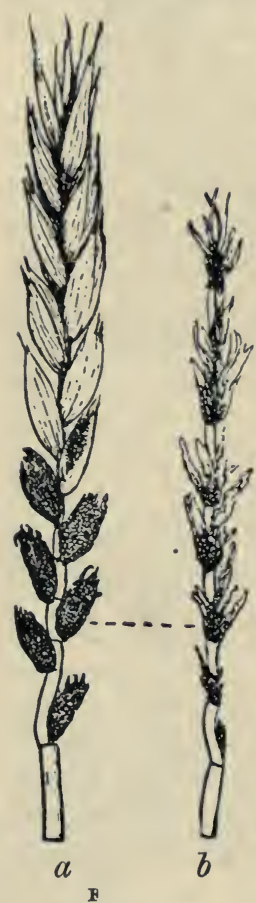

WHEAT SMUT. cealed, so that usually the kernels resemble masses of black powder. Such a head is represented at Fig. 81, $a$, engraved after Kellerman and Swingle. The powder soon blows away, leaving the bare chaff and stem, $b$. 'This disease is found, to a greater or less extent, wherever wheat is grown, but is seldom as destructive as the bunt. No successful method of combating it has yet been found. A good discussion of it occurs in the second report of the Kansas Experiment Station, 1889, pp. 261-268.

It was formerly supposed that the loose smut of oats was the same as that of wheat; but recent observations indicate that the fungi causing the two maladies are different species, and that they caunot pass from one plant to the other. Professor Bessey has shown that part of the heads of given stools of wheat may be affected with loose smut, and part be healthy.

\section{The Wheat Scab}

Fusisporium culmorum

This is a peculiar disease which attacks the heads and kernels of wheat. It is usually first noticed just as the heads are beginning to turn, when an examination of infested fields shows that with a portion of the heads the 
upper or lower half has prematurely whitened, leaving the rest green, the whitened part having on many of the glumes a more or less distinct pink or orange covering of the mycelium and spores of the fungus. Under $a$ high power of the microscope this fungus is seen to be composed of long curved spores, as shown in Fig. 82. According to the botanists, it is a species of Fusisporium. The kernels attacked by the fungus become mere shells, covered inside and out with mycelium (Fig. 83) and in passing through the thresher they are blown away with the chaff. The yield is sometimes greatly decreased. In 1890 I saw a field of one hundred acres in Madison County, Ohio, considered the finest wheat field in the

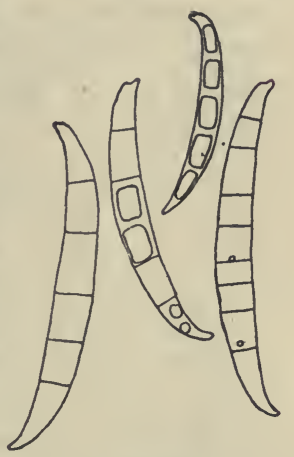

FIG. 82. SPORES OF WHEAT SCAB. MAGNIFIED. county, which was expected, shortly before harvest, to yield thirty-five to forty bushels per acre, so severely attacked by the disease that the yield was reduced to

FIG. 83. WHEAT KERNELS AFFECTED.BY SCAB.

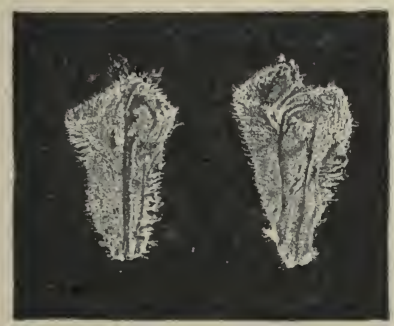

eight bushels per acre. Two other fields, one of twenty-five and the other of fifty acres, were shrunken in yield at least one-third, from the same cause. The fungus apparently gains access to the tender, undeveloped kernel, sapping its life and sending down feeders into the main axis of the head on which the kernel and inclosing chaff are borne. The functions of this part of the plant soon become locally deranged, and, in consequence, the supply of nutriment for the portion of the head above the 
affected part is cut off, causing it to stop growing and lose its green color. As the fungus develops it produces great numbers of spores, which give the pinkish color to the affected parts. As a rule, the disease is worse on weak-growing varieties, and those fields which are sowed latest. Consequently, vigorous growth and early blossoming are thought to be the chief safeguards against the malady.

\section{The Wheat Rust}

\section{Puccinia rubigo-vera}

Probably no disease of cereals causes a greater loss to American farmers than the rust of wheat. It appears to be known wherever wheat is grown, and is often responsible for the destruction of a large percentage of the crop. It has, until recently, been quite generally assumed, by botanists and others, that the fungus causing wheat rust in America is the same species that eauses it in Europe-a species known to science as Puccinia graminis - but it has lately been shown that our common rust is often an entirely different fungus, whose Latin name appears above. The European species passes one stage of its existence upon the barberry, causing the familiar cluster-cups, but the other fungus has no connection with the barberry. It has a first, or cluster-cup stage, which is passed on certain plants belonging to the Borage family; and has also two different stages upon wheat. The first of the wheat stages-but the second in the life-cycle of the fungus-is the red rust stage, called, by botanists, the uredo stage. It is in this condition that the fungus is most destructive. Later in the season an entirely different kind of spore is produced -the so-called teleuto-spore-which forms the third stage of the fungus. But recent investigations have shown that the second, or uredo-stage, is able to survire 
the winter and reproduce itself indefinitely, so that it is probable that, in many cases, this stage of the fungus is all that is necessary to explain its continued existence.

All farmers know with what marvelous rapidity wheat rust spreads, if wet weather occurs shortly before harrest. It is a disease for which, as yet, no successful remedy has been found. Full knowledge of its life-history is yet wanting, and, possibly, when more is known, successful preventives may be suggested. Early ripening varieties are less liable to damage than others. The fungus often passes the summer on volunteer wheat, hence this should be destroyed. A discussion of the life-history of the European wheat rust may be found in W. G. Smith's "Diseases of Field and Garden Crops" (pp. 147-207). The American rust is treated of in Bulletin No. 26, Indiana Experiment Station; Bulletin No. 5, Minnesota Experiment Station; and in various other periodicals. 


\section{FUNGI AFFECTING INDIAN CORN}

\section{The Corn Smut}

\section{Ustilago zece-mays}

The smut of Indian corn is one of the most widely distributed and generally known of the fungous diseases of plants. It probably occurs wherever this crop is extensively grown, and it has been known for many years. The amount of injury it does varies greatly, but has seldom been accurately determined. In the report of the Tenth Census of the United States, Professor Brewer writes that he has heard of instances in which the damage was estimated as high as sixteen per cent., although he had, himself, never seen a field which was injured to the extent of one per cent. Professor Bessey reports that in a garden patch where sweet corn had been grown for several successive years, sixty-six per cent. of the crop was ciestroyed by smut one season. The general average, the country over, howerer, probably does not exceed one or two per cent.

Although corn smut usually infests the ears of the plant, it. is occasionally found upon tassel, stem and leaves. On the ear it first appears as a white, malformed mass, representing, either the whole ear or a portion of the kernels (Fig. 84). The whiteness gradually becomes darker, finally changing into a brownish-black powdery mass, consisting of millions of the minute spores or reproductive bodies of the fungus. On the tassels the swellings are not so large, and on the stem and leaf their size varies greatly. 
When one of these spores comes in contact with a drop of water it soon germinates by sending out a little tube, which has the power of developing certain secondary spores, called sporidia. The sporidia themselves have the power of germinating, under favorable conditions, and in a liquid containing sufficient organic mat-

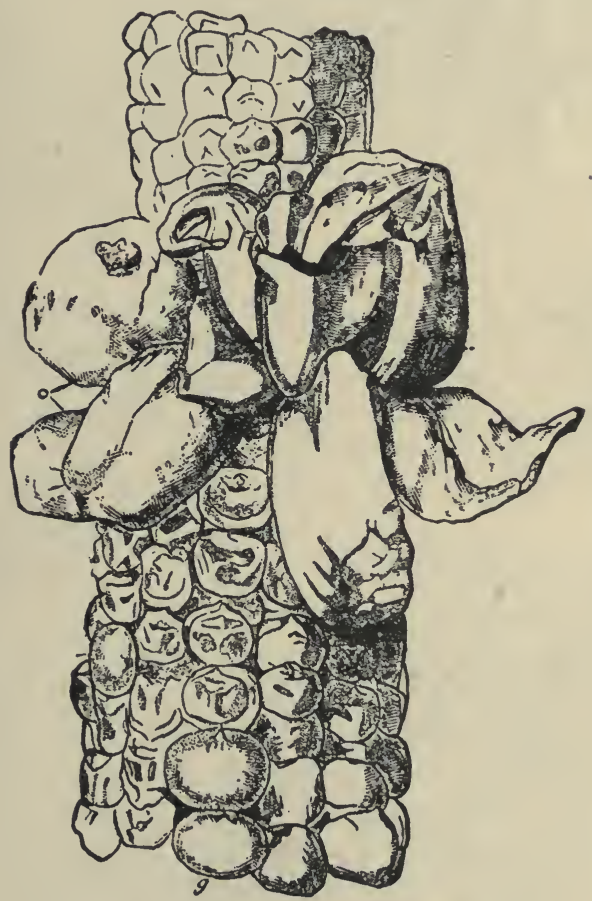

FIG. 84. PART OF SMUTTED EAR OF CORN.

ter for their nourishment (manure water, for example), they can continue growing and multiplying for an indefinite period. It is believed, by some authors, that these sporidia may develop in the barnyard, from the spores which find their way to the manure pile, and be carried 
to the field with the manure, finally infecting the plants, but this has not yet been definitely determined. 'The observations of Kuhn indicate that the germinating mycelium penetrates the very young corn plant at the root node and the first formed joint, and that after the corn gets well started the danger of infection by smut is passed. It has generally been supposed that the spores adhered to the seed, and caused infection; but recent experiments at the Kansas Experiment Station-in -hich corn kernels were rolled in smut spores, without

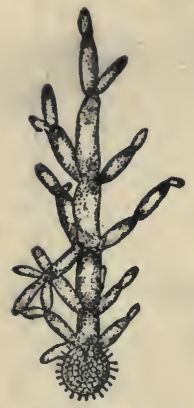

FIG. 85. SMUT SPORES GERMINAT-

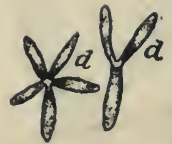
increasing the amount of smut in the resulting cropthrow so much doubt upun this assumption that Professor Kellerman thinks that " $\mathrm{further}$ investigation is necessary in order to determine the mode of infection," adding that this is "a point that must be settled before we can hope to employ rational methods for the prevention of this annoying and destructive pest."

It seems pretty well proven, however, that the smut can exist in the soil from year to year, and infect succeeding crops. The following experience, related by Professor Bessey, as occurring in Iowa a few years ago, shows this: "One season a piece of land, including about three-fourths of an acre, was planted with sweet corn for table use. Some smut made its appearance the first year, but it was all allowed to fall back to the ground. None of the stalks were removed, but all were plowed under, and the second season the ground was again planted with sweet corn, for table use as before. This time the smut was remarkably abundant, but again it was all allowed to fall upon the ground, and was 
plowed under with the stalks. The third season the ground was planted as before, and this time fully twothirds of the ears were affected with smut. In fact, the smut was so abundant that but little corn was gathered, and the crop was practically abandoned. The ground was found to be now so filled with smut as to unfit it for further use for corn, and it was consequently assigned to other uses. The lesson is very obvious. Smut left on the ground will produce smut the next year."

After the mycelium of the smut fungus has penetrated the corn plant it grows along with the latter, pushing its way through the tissues of the stem, and finally developing extensively, by means of many branches, in the ear or tassel. From this mass of branches the spores develop, the latter absorbing so much of the substance of the former that the mass of mycelium becomes gelatinous, and finally disappears, leaving in its place the familiar blackish, powdery mass of spores. Up to the time of maturity the smut mass is surrounded by a dull white membrane, which finally bursts and allows the spores to escape.

Many farmers believe that corn smut is very injurious to cattle when eaten by them. Cases of death attributed to this canse are not uncommon; but feeding experiments made by Professors Gamgee, Henry, and others, indicate that the amount of smut cattle are likely to eat, under ordinary circumstances, would do little, if any, injury. The only plant besides Indian corn upon which this kind of smut is known to develop, is a coarse grass called Teosinte, which is sometimes used as a forage plant in the Southern States.

Microscopic Characters.-The spores of corn smut are so minute that it has been estimated that from 30,000 to 50,000 of them will adhere to the moistened head of a common pin; that 25,000 of them, laid side by side in a straight line, would measure an inch; and 
that single cubic inch of smut would contain more than $15,000,000,000$ of them. The dry spores are globose, and brownish-black, with the outer surface thickly studded with elevated points. The method of germinition and of the formation of sporidia is well illustrated at Fig. 85. The inycelium is whitish, and the tips of the threads are able to penetrate the cells of the corn plant. 'The cells are also penetrated by the haustoria, or suckers from along the mycelial threads.

Treatment.--In the light of our present knowledge, measures looking toward the lessening of loss from smut must be largely of a preventive nature. As Professor Kellerman has pointed out, we must know the mode of infection of the corn plant by smut before we can be sure of the most rational remedy. The fact, however, that smut thrown or left upon the ground produces the disease in succeeding crops, and the apparent probability that infection may be brought about by the distribution of the spores, or sporidia, in manure, indicate (1) that rotation of crops should be practiced, and (2) that as much of the smut as possible should be destroyed before it comes to maturity. It will pay the careful farmer to cut out and burn, or bury, the smut balls before the membrane covering them bursts and allows the spores to escape. At the time of husking, all snut masses that have escaped detection should also be disposed of. "Where domestic animals are allowed to eat smut in the field they become the carriers of the spores, and their droppings, filled with the still living spores, become the centers of infection. No animal should be permitted to eat smitted corn, even though the owner be convinced of its harmlessness to the animai itself. The harm lies in the distribution of the spores, which are little, if at all injured, by passing through the alimentary canals of animals."

(Bessey.)

The soaking of seed corn in copper sulphate solutions to destroy the adhering smut spores, has frequently 
been recommended, but the failure of I'rofessor Kellerman's experiments, in attempting to increase the amount of smut by rolling the seed in the spores, indicates that this is hardly worth while, especially as the copper sulphate soaking has the effect of diminishing the vitality of the seed. If treatment of this kind were desirable, it would be better to adopt the hot water method used to destroy the smut of oats and wheat. From the fact that the smut enters the plant when very young, we should hardly expect that spraying the growing corn with the Bordeaux mixture, or other fungicides, would do any good; and recent experiments confirm this supposition.

Literature.-An excellent general account of corn smut, by Professor A. B. Seymour, may be found in the 1887 report of the Department of Agriculture (pp. 380-389).

\section{The Indian Corn Rust}

\section{Puccinia maydis}

The disease of Indian corn known as rust has at tracted comparatively little attention from American farmers, and, so far as its injuries are concerned, it is, indeed, of minor importance. It is fortunate that this is the case, for, as yet, no successful method of combating it has been suggested.

Corn rust is quite similar, in character and appearance, to the familiar red rust of wheat and oats. It usually appears about midsummer, in the shape of small, brownish, dust-like blotches on the surface of the corn leaf. These dust-like patches, or pustules, consist of the summer spores of the fungus; the spores are of a rich yellowish brown color, and are easily blown away by the wind. Toward the end of summer these brownish spores are replaced by blackish ones, so that the pustules then assume a blackish appearance. These dark-colored 
spores are the winter spores, and are very different in structure and appearance from the summer spores. Tho two kinds are produced from the same mycelium, and at certain seasons they may be found intermingled in the same mass, or pustule. This fungus usually only developes after the corn has gotten well along in its growth, so that the effect of its injury is less than if the very

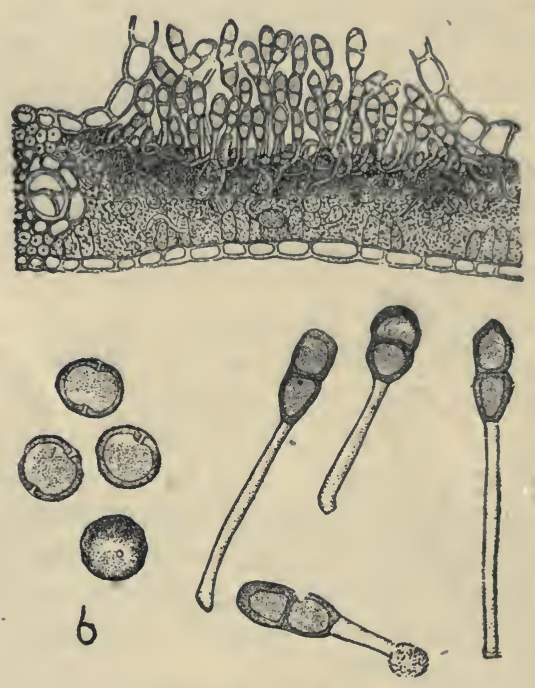

FIG. 86. CORN RUST.

$a$, Section of leaf showing teleuto-spores; $b$, uredo-spores; $c$, teleuto-spores.

young plants were attacked. Hence it seldom assumes a serious economic importance.

The brown summer spores (called by botanists uredospores) are nearly spherical, with the outer wall thickly studded with minute pointed projections (Fig. 86 b). They are about one-one thousandth of an inch in diameter, and are borne on slender stalks arising from the 
mass of the mycelium, from which they readily separate. They serve to spread the disease during a limited time in summer, but are supposed not to survive the winter. The blackish winter spores (called by botanists the teleuto-spores) are decidedly different in structure and appearance from the others. A cross section of a corn leaf through one of the blackish pustules is represented at $a$, Fig. 86. As will be seen, the spores are borne on stout stalks, to which they remain attached, $c$. The spores themselves are so divided by a partition across the middle that they are practically double; each part can germinate independently of the other. These spores survive the winter.

Treatment.-As already intimated, no practical remedy is known for this disease; and, fortunately, none as yet is seriously needed. A more extended discussion of this malady is published in the 1887 report of the Department of Agriculture (pp. 389-391).

\section{The Bacterial Disease of Corn}

In 1889 Professor T. J. Burrill, of the University of Illinois, announced the discovery of a peculiar malady of Indian corn, which he had proven was due to the presence of bacteria. The disease was then prevalent over a considerable area in Illinois, and investigations since have indicated that it does much damage-often not understood, or else attributed to other causes-over a large portion of the corn-growing region of the West. As the disease is an obscure one, not easily recognized or described, Professor Burrill's account of its appearance is quoted below at length.

External Manifestations.- "The first indication of this disease in a field of corn, as noticed in ordinary observation, is the dwarfed condition of the young plants. This commonly occurs in spots of various sizes, from a few square rods, to an acre or more, and often, 
though by no means always, on soil of a character somewhat different from the rest of the field. It seems hard to designate what special condition or quality of soil is most usually associated with the disease; but, upon the whole, it is found in the rich spots, rather than in those of the poorer quality. In many cases it is upon the lowest ground, whether or not water has temporarily stood in the hollows. The most definitely bounded area noticed was upon a spot which had, until the year previous, been too wet for tillage, but which had been tile drained and broken up, the sod having rotted.

But ordinarily there are no such definite borders to the infected areas, and often nothing whatever to suggest a reason for their peculiar distribution.

"Upon closer observation it is found that young diseased plants, besides being smaller than the healthy ones, are uniformly yellowish in color, the lowest leares showing worst. As death overtakes these leaves, they apparently succumb by a general decline from the healthy state, and rarely die, and wither chiefly at the ends and margins as in some other cases. When some of the affected plants are pulled from the ground they are found to give way too easily, in consequence of the death, to a greater or less extent, of the oldest and lowest roots. In anything like severe cases at least one-half the roots-always the lowest-are injured, and usually dead. The bottom portion of the stalk is likewise affected, and will be found dead or dying. If split longitudinally through the middle, the inner tissue of this lower part is seen to have a uniform dark color ; and a similar discoloration, gradually becoming less and less pronounced, appears in the next succeeding nodes, or joints, while the spaces between them (internodes) are seemingly healthy. On the surface, when carefully freed from dirt, brownish, corroded spots can be found, sometimes strictly bordered, again diffusely spreading. 
Sometimes masses of semi-transparent, rather firm, gelatinous material are found upon these external corrosions. "After midsummer, especially, the disease becomes apparent through discolorations of the portions of the leaves called the sheaths, which closely invest the stalk. Thuse leaf-sheaths become variously spotted, as obserred from the exterior. Sometimes the watery-brown portions are mere specks ; sometimes large irregular patches, and of all grades between these extremes. The discolorations become brown, of a half-rotten appearance. Occasionally there is a little reddish color, more often bordering the brown. If, now, these affected leaves are stripped from the stalk, it will be found that the evidence of injury is much more conspicuous on their inner side. The injured patches are larger, have a more watery appearance, and sometimes are more or less smeared with the same gelatinous substance previously mentioned as occurring on the diseased stem below the ground; but here on the leaf-sheaths it is usually spread in a thinner coating, or layer, instead of in round masses. This infection of the leuf-sheaths evidently comes later in the season than the first noticed form of the disease on the roots. It seems also to be evenly distributed through the field, and to occur upon large as well as small plants.

"Finally, the ears are, at least occasionally, affected. Externally, the appearance of the outer husks is like that of the diseased leaf-sheaths. Internally, in the worst stage, the whole ear-husks, which should be still green, young cob and kernels, and the mass of "silks" -is reduced to a moist state of corruption, though not ill-scented. The parts lose their normal rigid, or turgid quality, appear as if wilted, and are packed closely together, if not actually adhering by the gummy exudation from the tissues. Very often these ears subsequently become moldy, penetrated through and through 
by a close, very white, felt-like fungus. Possibly this fungus sometimes makes its inroads into the ear without the bacteria as forerunners; but from present knowledge it seems probable that it is a secondary intruder. These moldy ears are, in certain seasons, very numerous, and are readily recognized by the husker, as "well as by the buyer, when the loads are sent to market."

Microscopic Characters.-When placed under a very high power of the microscope, the juices from affected portions of corn plants are seen to be swarming with minute bacteria. These bacteria, when magnified

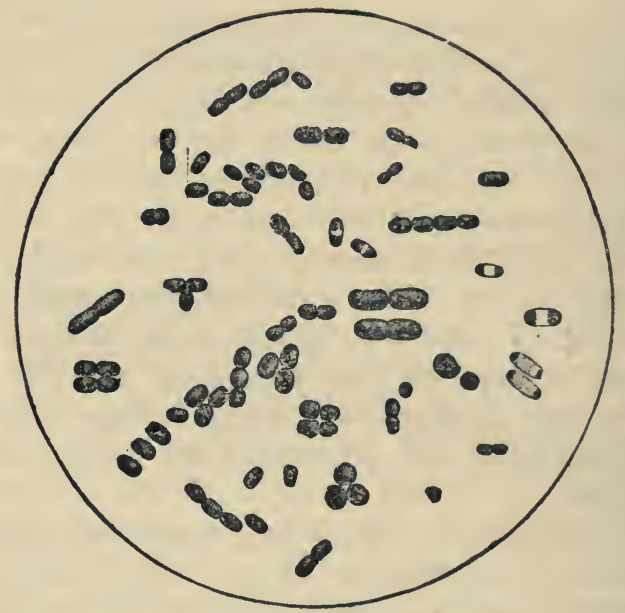

FIG. 87. BACTERIA OF CORN DISEASE.

nearly three thousand times, resemble Fig. 8\%. Each individual measures less than one-twenty-five thousandth of an inch in length. They frequently form jelly-like masses on the inside of the leaf, these masses consisting of the bacteria themselves held together by the mucilaginous substance they exude. 
Possible Effect on Cattle.-Investigations made in Nebraska, by Dr. F. S. Billings, indicate the probability, and, in the opinion of Dr. B., the certainty, that when cattle eat corn affected by this disease the germs present may cause the illness, and sometimes the death of the animals. He calls it the "Cornstalk Disease in Cattle," and concludes an elaborate report of his investigations with this statement: "When cattle become unaccountably ill immediately after having been turned into a stripped cornstalk field, and that illness is accompanied by the phenomena previously detailed, it may be taken for granted that it is this corn-fodder disease, and no other."

Treatment.-No method of preventing the disease in corn has yet been suggested, except that of crop rotation, and so little is known of what other plants are attacked by the same germs that this is merely a suggestion. Care should be taken that cattle are not turned into fields of corn that have patches affected by the disease; at least not until all such patches have bcen cut and the fodder burned.

Literature.-An account of Professor Burrill's investigations may be found in the Proceedings of the Tenth Meeting of the Society for the Promotion of Agricultural Science (1889, pp. 19-27), and in one of the earlier Bulletins of the Illinois Experiment Station. Dr. Billings' investigations are reported in the Bulletin of the Nebraska Experiment Station (Nos. 7-10, pp. 165-210; June, 1889). 


\section{FUNGI AFFECTING BROOM CORN AND SORGHUM}

\section{The Sorghum Blight}

\section{Bacillus sorghi}

This disease is caused by bacteria, and so is somewhat similar to the bacterial disease of corn already discussed. It occurs upon both sorghum and broom corn, and is especially characterized by the red markings it produces upon affected plants. Its nature was first worked out by Professor T. J. Burrill, who gives the following description of the external manifestations of its presence :

"Sometimes the appearance of injury is noticeable upon young plants. They grow very slowly, are slender and yellowish in color, and are easily pulled from the ground. The lower leaves die, having previously shown discolored (yellow or red, mostly the latter) patches on various parts of their surface. Not unfrequently these conditions prevail in special areas of the field; perhaps several acres, not apparently different in composition of soil, condition of drainage, etc., will have throughout, their extent this dwarfed and sickly crop, while the rest of the plantation remains healthy and vigorous. More often the evidence of disease appears, to a greater or less extent, over the entire field, all, or an exceedingly variable proportion of the plant suffering. Not unfrequently stalks, four or five feet high, can be lifted with ease from the soil, the foots being mostly dead and rotten.

"Upon the ærial parts the conspicuous evidence of disease, aside from the smaller size of affected plants, is 
the red-blotched leaves and leaf-sheaths. The latter are particularly spotted at the upper portion, just below the ligule. If they are stripped from the stalk the carmine coloration is seen to be conspicuously brilliant inside, and often extending over a large area of the interior surface of the sheath. On the leaves themselves the spots are usually more numerous along the mid-veins. The stalks are usually not locally affected until late in the season, when they, too, show evidence of the disease by the appearance of red or rusty spots. On the "brush" of broomcorn similar discolored patches are to be observed, and these directly injure the product. The rusty, corroded places may be frequently found on the brush of the manufactured brooms.

"The diseased roots also turn red but soon decay, and, of course, lose the bright color. The oldest roots die first, and, as new ones are successively emitted from the base of the stem in the order commonly occurring in these plants, they, in turn, become successively affected and perish. This is why the plant yields to so slight a pull, while healthy ones resist a vigorous effort. Upon close examination it is evident that the exterior part of the roots or cortex is the portion in which the disease is resident, the woody fibers of the interior remaining for a long time unchanged, except through natural decay after the death of the whole root. But the woody part is stained from contact with the external layer."

It has been conclusively shown, both by Professor Burrill, and by Messrs. Kellerman and Swingle, that this disease is due to a distinct species of bacteria, requiring a high microscopic power to be seen, and special skill and training to be successfully studied. When highly magnified these bacteria bear a general resemblance to Fig. $8 \%$.

Treatment.-Rotation of crops seems to be the best method of preventing the development of this dis- 
ease. According to Professor Burrill, "crops are sometimes injured in the way described on land not previously planted with sorghum or broomcorn; but the danger is invariably less," and "field practice has given excellent demonstration of this system of management." It is also advisable to burn refuse stalks and stubble, so far as is practicable.

Literature.-Professor Burrill's article was published in the Proceedings of the Eighth Annual meeting of the Society for the Promotion of Agricultural Science (1887, pp. 30-36). Messrs. Kellerman and Swingle have published their results in the report of the Kansas Experiment Station (1888, pp. 281-302). An additional note occurs in the Journal of Mycology for December, 1889 (v. 5, pp. 195-199).

\section{The Grain Smut of Sorghum}

\section{Ustilago sorghi}

The individual seeds of sorghum heads are sometimes attacked by smut. Such seeds become greatly swollen - especially lengthwise-and consist of a grayish outer membrane surrounding a mass of dark powder. The disease is illustrated and briefly described by Professor Kellerman, in Bulletin No. 23 of the Kansas Experiment Station.

\section{The Head Smut of Sorghum}

Ustilago reiliana

This disease duffers from the last in that the whole head of the sorghum stalk is usually diseased, being "converted into a large, continuous, or lobulated mass covered with a white membrane. The latter soon ruptures and exposes the black, powdery mass of spores." This fungus is discussed and figured in the bulletin above mentioned. 


\section{FUNGI AFFECTING ALFALFA}

\section{The Alfalfa Leaf=blight}

\section{Cercospora helvola var. medicaginis}

This disease has been studied by Professor F. D. Chester, of Delaware, who reports that it "shows itself upon the leaf as sub-circular, or elliptical spots of a smoky brown, or almost black color, equally visible upon both sides, and varying from one-sixteenth to one-thirtysecond of an inch in diameter. The spots are without well-defined borders, which, when closely examined, are somewhat irregular, shading indistinctly into the surrounding leaf tissue. Spots coalescing cause the leaf to

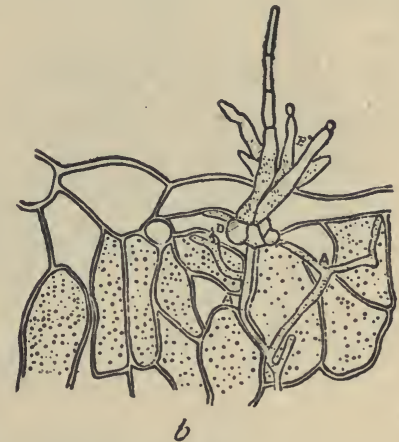

FiG. 88. ALFALFA BLIGHT FUNGUS. $a$, Spore; $b$, section of leaf. Magnified. turn yellow and brown, completely destroying it." The same fungus is believed, occasionally, to attack the red clover and scarlet clover, although it is seldom, if ever, seriously destructive to these crops. The mycelium threads of the fungus push about between the cells of the leaf, absorbing their contents, and causing the discoloration of the foliage. When ready to fruit, the threads develop abundantly at certain points just beneath 
the epidermis of the leaf, and then push out several stalks, on the ends of which the spores are produced. The latter (Fig. $88 a$ ) are long and slender, and divided by several transverse partitions. 'They germinate when on moist alfalfa leaves, by sending out a slender thread, which penetrates the skin of the leaf and starts the fungus anew.

Treatment.-Upon this point Professor Chester says: "In case it should be necessary seriously to combat this difficulty, the writer would advise that all diseased patches or areas be cut and burned, or composted with an excess of lime."

Literature.-The only article of importance concerning this disease yet published is the one above referred to, which may be found in the Second Report of the Delaware Experiment Station (1889, pp. 95-97). Another disease of alfalfa is briefly described in the same connection, and another in the report for 1890 .

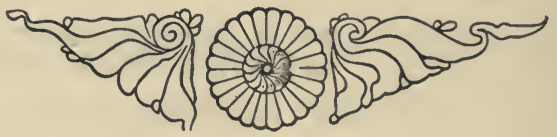




\section{FUNGI AFFECTING CLOVER}

\section{The Clover Rust}

\section{Uromyces trifolii}

Although this disease has been known in Europe as a clover enemy for a long time, it has only recently been noticed in this country. It is now widely distributed, however, occurring from Connecticut, in the east, to

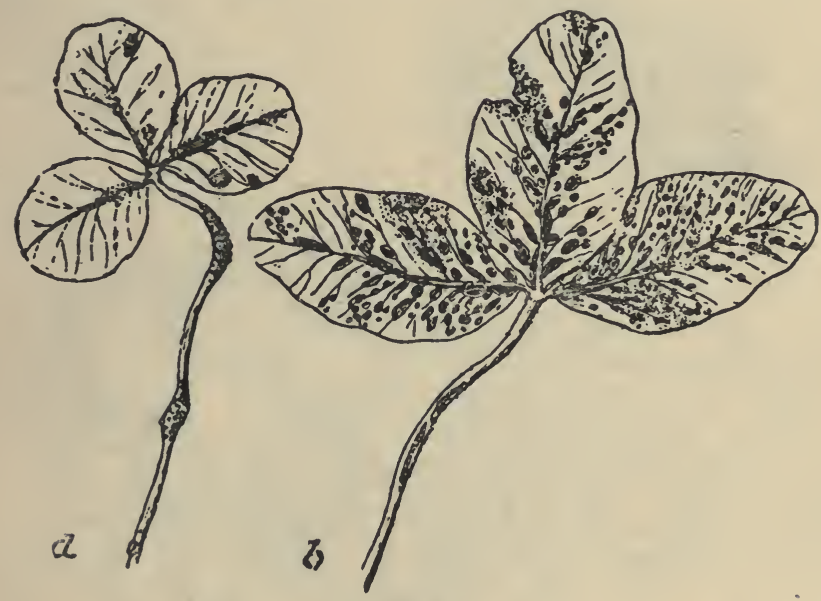

FIG. 89.

$\alpha$, White clover leaf showing æecidium stage; $b$, red clover leaf showing uredo stages.

Colorado, in the west. It is occasionally so abundant as to injure seriously fields of red clover. Leaves affected by the disease are more or less thickly covered with well-defined, oblong, brown powdery spots, as shown in Fig. 89. 
Like various other members of the family of rusts to which this fungus belongs, it exists in three distinct
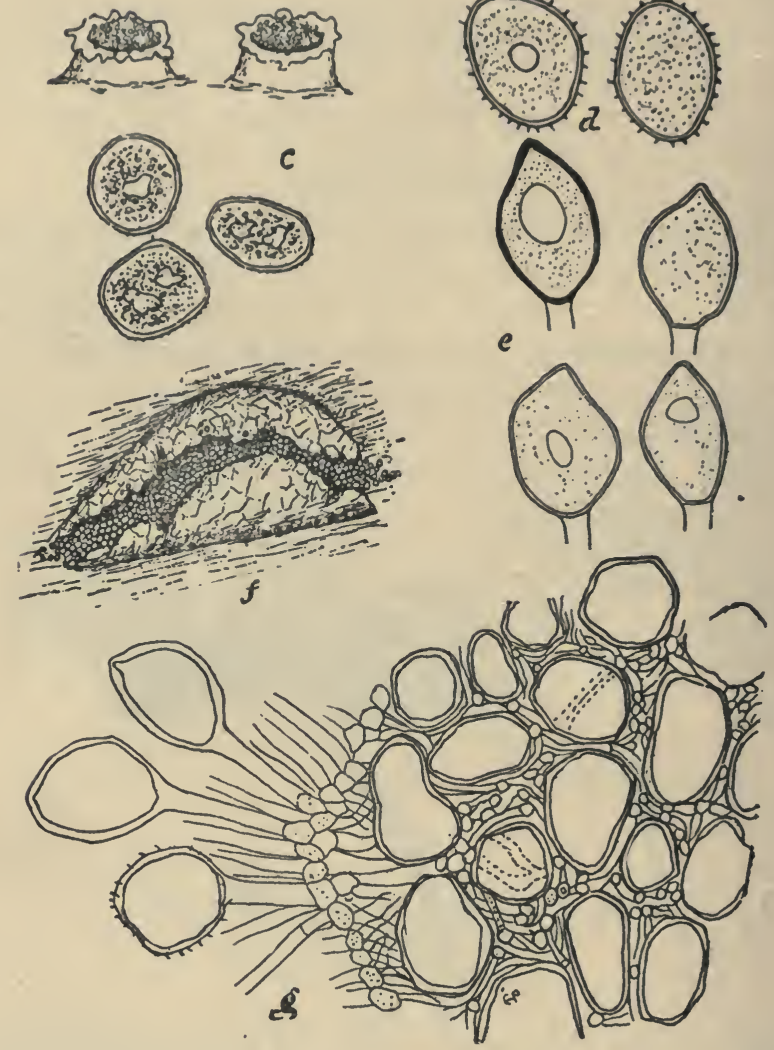

FIG. 90. CLOVER RUST.

$c$, Cluster-cups and recidium spores; $d$, uredo spores; $f$, uredo pustule on clover leaf; $e$, teleuto spores; $g$, cross-section of stem showing mycelium between cells; also two teleuto spores and one uredo spore.

successive stages. Early in the season it appears-principally upon white clover plants-in the so-called cecid- 
ium stage. It affects both the leaves and stems, producing cup-like swellings, which are filled with orange colored spores. A white clover leaf attacked by this stage of the fungus is shown in Fig. $89 a$, while at $c$, Fig. 90, may be seen two of the cluster-cups magnified, and some of the orange colored spores still more enlarged. These orange spores are blown to other clover plants, especially red clover, where they germinate and send their little tubes into the leaf tissues. These tubes start the mycelium which develops between the leaf cells for some time before any external indication of its presence occurs. Then it produces, at certain places just beneath the outer skin of the leaflets, numbers of small reddishbrown spores, which finally rupture the skin (as seen in Fig. $90 f$ ), and are set free. When magnified $(d)$ these spores are shown to have their outer surfaces studded with minute pointed tubercles. This is the second, or uredo stage of the fungus; these spores are called uredospores. After these are mostly blown away-presumably to start the disease in new situations-there is produced from the same mycelium, and in the same spots, the third form of spores called the teleuto-spores $(e)$. These are supposed to carry the fungus through the winter, although it is probable that it also passes the winter in the mycelium in white clover plants.

Treatment.-According to Miss J. K. Howell, of the Cornell University, to whom we are indebted for much of our knowledge of this disease, the early crop of red clover is not likely to be injured by rust. In consequence, she makes the following suggestions as to remedies: "As the second crop is likely to suffer greatly if the midsummer is cool, and as clover becomes a valuable fertilizer when plowed in, the fields should be carefully watched in such seasons, and the crop might be plowed under to advantage. Burning the clover fields in the fall would probably have some effect in checking the 
spread of the disease during the next season; but the application of fungicides seems impracticable."

Literature.-The most complete account of this disease in American literature is that of Miss Howell, referred to above, which is found in Bulletin 24 of the Cornell Experiment Station. Professor Pammel has discussed it in Bulletin No. 13 of the Iowa Station; and various notes concerning it have been published elsewhere.

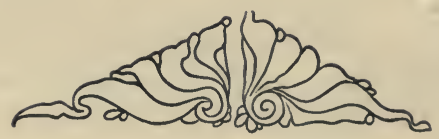




\section{IN DEX}

Alfalfa, Fungi aftectin

Apple, Fungi affecting, . $\quad$. $\quad$. $\quad$. $\quad 27$

bitter rot, . . . . . . 33

powdery mildew, . . . . $\quad$. 30

rot, $\quad . \quad$. . . . . 33

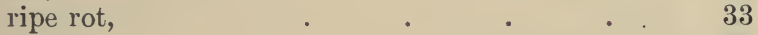

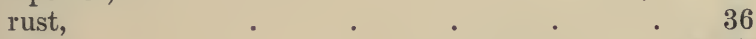

scab, . . . . . . $\quad 2,27$

twig blight, . $\quad . \quad$. $\quad$. $\quad$. 39

Ascochyta petunice, . . . . . . $\quad$. 125

Bacillus sorghi, . . . . . . 214

Bean, Fungi affecting, . _ . $\quad 129$

anthracnose, . $\quad . \quad . \quad . \quad . \quad 129$

blight, . . . . . 132

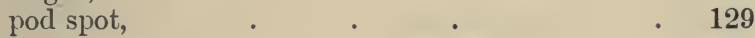

rust, . . . . 132

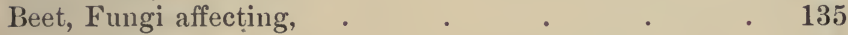

leaf-spot, $\quad . \quad \ldots \quad$. $\quad . \quad 136$

rust, $\quad . \quad$. $\quad . \quad$. $\quad . \quad$. 135

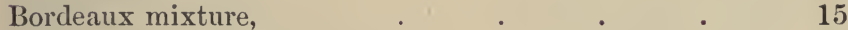

and arsenites, . . . . . . . 20

Broom corn, Fungi affecting, . . . . . $\quad 214$

Cabbage, Fungi affecting, . . . . . 138

club root, $\quad$. $\quad$. $\quad . \quad . \quad 138$

Carbonate of copper, . . . . . . . $\quad$. 18

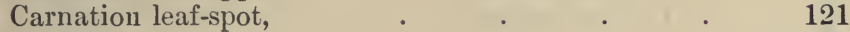

rust, $\quad$. $\quad$. $\quad$. $\quad$. 120

Catalpa leaf-spot, $\quad$. $\quad$. $\quad . \quad$. $\quad$. 111

Cauliflower, Fungi affecting, . . . . . . 138

Celery, Fungi affecting, . . . . . . 144

blight, $\quad . \quad$. . . . 144

leaf-blight, $\quad$. $\quad$ • $\quad$.

soft-rot, $\quad . \quad$. . . . . . 149

Ceratocystis fimbriata, . . . . $\quad$. 172 
Cercospora angulata,

" apii,

" lieticola,

" helvola,

Cherry, Fungi affecting,

Chester spraying cart, .

Cladosporium carpophilum, . . . . . . r (i.)

Clover, Fungi affecting, . . . . . 219

rust,

Cocoma nitens,

Colletotrichum lagenarium,

"

spinacere,

129

177

Conidia,

Copper arsenic solution, .

chloride,

Cottonwood leaf-rust,

Cucumber, Fungi affecting,

Currant, Fungi affecting,

anthracnose,

- Cylindrosporium padi,

Fau celeste,

Entomosporium maculatum,

Flowers, Fungi affecting,

hollyhock rust, mignonette disease, petunia blight, verbena mildew,

Fungi, losses due to,

methods of studying, . $\quad . \quad \ldots \quad$. 11

$$
\text { " " } \text { " } \text { preventing, }
$$

\section{parasitic,}

Fungicides, application of the important and insecticides use of 
Fusisporium culmorum,

Page

Glocsporium fructigenum, . • . • . . . . . 33

nerrisequum, . . . . . 113

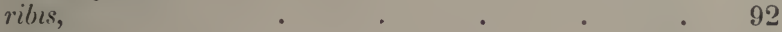

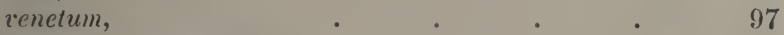

Gooseberry, Fungi affecting, . . . . . $\quad .91$

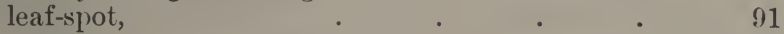

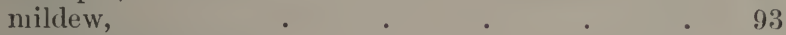

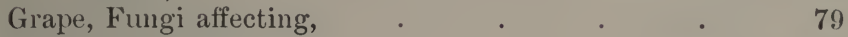

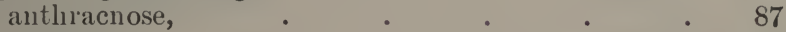

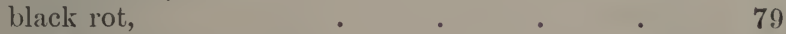

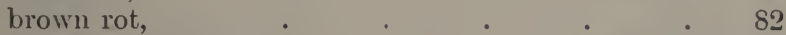

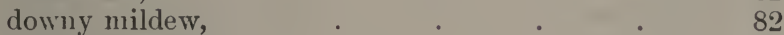

powdery mildew, . $\quad . \quad$. $\quad . \quad$. $\quad 85$

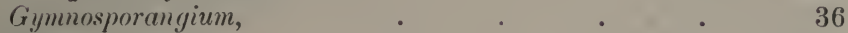

Hollyhock rust, . . . . . . 119

Indian corn, Fungi affecting, _ . . . $\quad 202$

bacterial disease, . . . . . . 209

rust, $\quad$. $\quad$. . . . 207

smut, $\quad . \quad$. $\quad . \quad$. $\quad . \quad$. 202

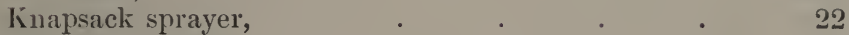

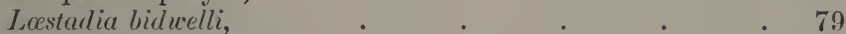

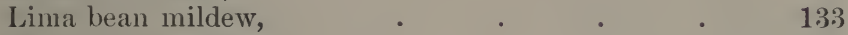

Macrosporium solani, . $\quad$. $\quad$. $\quad . \quad$. 165

Maple leaf-spot, $\quad$. $\quad$. $\quad$. $\quad$. 113

Melampsora populina, . $\quad$. $\quad$ • $\quad$. $\quad$. 112

Melons, Fungi affecting, . $\quad$. $\quad$ • $\quad$. 160

bacterial blight, . $\quad . \quad$. $\quad . \quad$. 160

leaf-spot, $\quad$. $\quad . \quad$. $\quad . \quad 163$

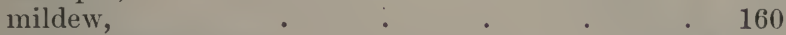

Micrococcus amylovorus, _ . . . . . . . .

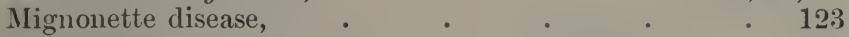

Modified eau celeste, . $\quad$. $\quad$. $\quad$. $\quad$. $\quad 18$

Monilia fructigena, . . . . 2, . . . $6,66,73$

Mushrooms,

Nozzles,

Oats, Fungi affecting, . . . . . . . . 187 loose smut, $\quad . \quad \ldots \quad$. $\quad . \quad$. 187 rust,

Oidlium erysiphioides,

Onion, Fungi affecting, . _ . . . . 150 mildew,

smut,

150

spot diseases,

2,152

157

Oospora scabies,

168 
Parasitic fungi,

Peach, Fungi affecting,

brown rot,

leaf-curl,

rosette,

yellows,

Pear, Fungi affecting,

blight,

leaf-blight,

scab,

l'eromospore,

$$
\text { effusa, }
$$

schleideniana,

viticola,

Petunia blight,

Phyllosticta acericola,

$$
\text { " catalpa, }
$$

Pleragmidlium mucronatum,

Phytophora phaseoli,

Plasmodiophora brassica', .

Plasmopara cubensis,

Plowrightia morbosa,

Plum, Fungi affecting,

black knot, brown rot, fruit scab, fruit spot, leaf-blight, leaf rust, pockets,

Podosphcera oxyacanthce, Potato, Fungi affecting, bacterial blight, downy mildew, early blight, late blight, leaf-spot, scab,

Potassium sulphide, Puccinia malvacearum,

$$
\begin{aligned}
& \text { " mayclis, } \\
& \text { " pruni-spinosce, } \\
& \text { " rubigo-vera, }
\end{aligned}
$$


Quince, Fungi affecting,

black rot,

fruit spot,

leaf-blight,

rust,

twig-blight,

Raspberry, Fungi affecting,

anthracnose,

orange rust,

Roestelia,

"6

aurantiaca,

Rose, Fungi affecting,

mildew,

phragmidium,

114

rust,

Saprophytes,

Saprophytic fungi,

Septoria cerasina,

" dianthi,

" petroselini,

121

" ribis,

Shade trees, Fungi affecting,

Soda hyposulphite,

Sorghum, Fungi affecting,

214

blight,

214

grain smut,

216

head smut,

216

Splaceloma ampelinum, . $\quad$. $\quad$. $\quad$. $\quad$. 87

Sphcerella fragarice,

Sphceropsis malorum,

Sphcerotheca mors-uve,

Spinach, Fungi affecting,

Spraying pumps,

Strawberry, Fungi affecting, 
Sycamore blight,

Sweet potato, Fungi affecting, . . . . $\quad 172$

black rot,

172

Swar'm spores,

'Taphrina deformans, pruni,

Tilletia foetens,

Tomato, Fungi affecting,

bacterial blight,

rot,

winter blight,

Uncinula ampelopsislis,

Urocystis cepula,

Uromyces lietce,

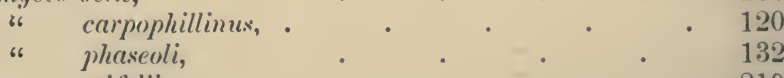

" trifolii,

Ustilago aience,

"6 reiliana,

"sorghi,

" tritici,

" zecr-mays,

Verbena mildew,

Vermicularia circinans,

Water,

Wheat, Fungi affecting, . . . . . . 194 bunt,

loose smut,

- rust, scab,

stinking smut,

Weather, relation to diseases, 
SENT FREE ON APPLICATION.

\section{DESCRIPTIVE CATALOGUE}

\section{- $\mathrm{OF}-$ - \\ RURAL BOOKS,}

CONTAINING 116 8vo. PAGES,

I'rofusely Illustrated, and giving Full Descriptions of NeARLY 600 WORKS ON THE FOLLOWING SUBJECTS:

Farm and Garden,

Fruits, Flowers, Etc.

Cattle, Sheep, and Swine,

Dogs, Horses, Riding, Etc.,

Poultry, Pigeons, and Bees,

Angling and Fishing,

Boating, Canoeing, and Sailing,

Field Sports and Natural History,

Hunting, Shooting, Etc.,

Architecture and Building,

Landscape Gardening,

Household and Miscellaneous.

PUBLISHERS AND IMPORTERS :

\section{ORANGE JUDD COMPANY, 52 \& 54 Lafayette Place, New York.}

Books will be Forwarded, postpaid, on receipt of Price. 


\section{Mushrooms: How to Grow Them.}

Any one who has an ordinary house cellar, woodshed or barn, ean grow Mushrooms. This is the most practieal work on the subjeet ever written, and the only book ou growing Mishrooms published in America. The anthor deseribes how he grows Mushroom 3, and how they are grown for proft by the leading market garleners, and for home use by the most snecessful private growers. Engravings drawn from nature expressly for this work. By Wm. Falconer. Clotlı. Price, postpaicl.

\section{Land Draining.}

A Handbook for Farmers on the Principles and Practice of Draining, by Manly Miles, giving the results of his cxtended experience in laying tile drains. The directions for the laying out and the construetion of tile drains will enable the farmer to avold the errors of imperfect construction, and the disappointment that must necessarily follow. This manual for praetieal farmers will also be fcund convenient for referenees in regard to many questions that may arise in crop growing, aside from the special subjects of drainage of whieh it treats. Cloth, $12 \mathrm{mo}$.

1.00

\section{Allen's New American Farm Book.}

The very best work on the subjeet; comprising all that ean be eondensed into an available volume. Originally by Riehard L. Allen. Revised and greatly enlarged by Lewis F. Allen. Cloth, 12no. 2.50

\section{Henderson's Gardening for Profit.}

By Peter Henderson. The standard work on Market and Family Gardening. The successful experience of the author for more than thirty years, and his willingness to tell, as he doe $\mathrm{in}$ this work, the secret of his suecess for the benefit of others, enables him to give most valuable information. The book is profusely illustrated. Cloth, $12 \mathrm{mo}$.

\section{Henderson's Gardening for Pleasure.}

A guide to the amateur in the fruit, vegetable and flower garien, with full descriptions for the greenhouse, eonservatory and window garden. It meets the wants of all classes in eountry, city and village wno keep a garden for their own enjoyment rather than for the sale of products. By Peter Henderson. Finely Illustrated. Cloth, $12 \mathrm{mo}$.

\section{Johnson's How Crops Grow.}

New Editiou. A Treatise on the Chemical Composition, Structure and Life of the Plant. Revised Edition. This book is a guide to the knowledge of agricultural plants, their composition, their structure and modes of development and growtlı; of the eomplex organizations of plants, and the use of the parts; the germination of seeds, and the food of plants obtained both from the air and the soil. The book is a valuable one to all real students of agriculture. With numerous illustrations and tables of analysis. By Prof. Samuel W. Johnson of Yale College. Cloth, $12 \mathrm{mo}$. 


\section{Johnson's How Crops Feed.}

A Treatise on the Atmosphere and the Soil, as related in the Nutrition of Agricultural Plants. This volume-the companion and complement to "How Crops Grow"-has been welcomed by those who appreciate the scientific aspects of agriculture. Illustrated. By Prof. Samuel W. Johnson. Cloth, $12 \mathrm{mo}$.

\section{Market Gardening and Farm Notes.}

By Barnct Landreth. Experiences and Observations for both North and South, of interest to the Amateur Gardener, Trucker and Farmer. A novel feature of the book is the calendar of farm and garden operations for each month of the year; the chapters on fertilizcrs, transplanting, succession and rotation of crops, the packing, shipping and marketing of vegetables, will be especially useful to market gardencrs. Cloth, $12 \mathrm{mo}$.

1.00

\section{Forest Planting.}

A Treatise on the Care of Woodlands and the Restoration of the Denuded Timber-Lands on Plains and Mountains. By H. Nicholas Jarchow, LL. D. The author has fully described those European methods which have proved to be most useful in maintaining the superb forests of the old world. This experience has been adapted to the different climates and trees of America, full instructions being given for forest planting on our various kinds of soil and subsoil, whether on mountain or valley. Illustrated, $12 \mathrm{mo}$.

\section{Harris' Talks on Manures.}

By Joscph Harris, M. S., author of "Walks and Talks on the Farm," "Harris on the Pig," etc. Revised and enlarged by the author. A series of familiar and practical talks between the author and the Deacon, the Doctor, and other neighbors, on the whole subject of manures and fertilizers; including a chapter especially written for it, by Sir John Bennet Lawes of Rothamsted, England. Cloth, $12 \mathrm{mo}$.

\section{Truck Farming at the South.}

A work which gives the experience of a successful grower of vegetables or "truck" for Norther" markets. Essential to any one who contemplates entering this promising field of Agriculture. By A. Oemler of Georgia. Illustrated, cloth, $12 \mathrm{mo}$.

\section{Sweet Potato Culture.}

Giving full instructions from starting the plants to harvesting and storing the crop. With a chapter on the Chinese Yam. By James Fitz, Keswich, Va., author of "Southern Apple and Peach Culture." Cloth, $12 \mathrm{mo}$.

\section{Heinrich's Window Flower Garden.}

The author is a practical florist, and this enterprising volume embodies his personal experiences in Window Gardening during a long period. New and enlarged edition. By Julius J. Heinrich. Fully illustrated. Cloth, $12 \mathrm{mo}$. 


\section{STA NDARD BOOKS.}

\section{Greenhouse Construction.}

By Prof. I. R. Taft. A complete treatise on Greenhouse structures and arrangements of the various forms and styles of Plant Houses for professional tlorists as well as amateurs. All the best and nost approved structures are so fully and clearly described that anyoue who desires to build a Greenhouse will have 110 diffeulty in determining the kind best suited to his purpose. The moderu and most successful incthods of heating and ventilating are fully treated upon. Special eliapters are devoted to houses usel for the growing of one kind of plants exclusively. The construction of hotbeds and frames receives appropriate attention. Over one liundred excellent illustrations, specially engraved for this work, make every point clear to the reader and add considerably to the artistic appearance of the book. Cloth, $12 \mathrm{mo}$. 1.50

\section{Bulbs and Tuberous-Rooted Plants.}

By C. L. Allen. A complete treatise on the History, Description, Methods of Propagation and full Directions for the successfui culture of Bulbs in the garden, Dwelling and Greenhouse. As generally treated, bulbs are an expensive luxury, while, when properly managed, they afford the greatest amount of pleasure at the least cost. The author of this book lias for many years made bulb growing a specialty, and is a recognized authority on their cultivation and management. The illustrations which embellish this work have been drawn from nature, and have been engraved especially for this book. The eultural directions are plainly stated, practical and to the point. Cloth, $12 \mathrm{mo}$.

\section{Henderson's Practical Floriculture.}

By Peter Henderson. A guide to the silcessful propagation and cultivation of florists' plants. The work is not one for florists and gardeners only, but the amatenr's wants are constantly kept in mind, and we have a very complete treatise on the cultivation of flowers under glass, or in the open air, suited to those who grow flowers for pleasure as well as those wlio make them a matter of trade. Beautifully illustrated. New and eularged edition. Cloth, $12 \mathrm{mo}$.

\section{Long's Ornamental Gardening for Americans.}

A Treatise on Beautifying Homes, Rural Districts and Cemeteries. A plain and practical work at a moderate price, with numerous illustrations and instructions so plain that they may be readily followed. By Elias A. Long, Landscape Architect. Illustrated, Cloth, $12 \mathrm{mo}$.

\section{The Propagation of Plants.}

By Andrew S. Fuller. Illustrated with numerous engravings. An eminently practical and useful work. Describing the process of hybridizing and crossing species and varieties, and also the many different modes by whieh cultivated plants may be propagated and mulliplied, Cloth, $12 \mathrm{mo.}$ 

$3 x+3$

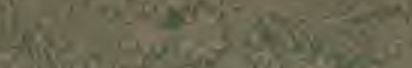

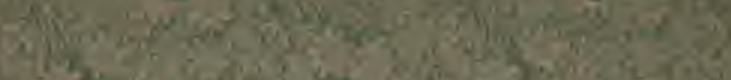

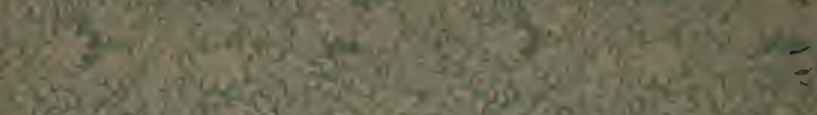

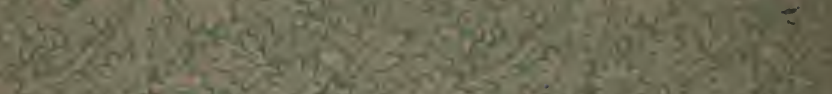

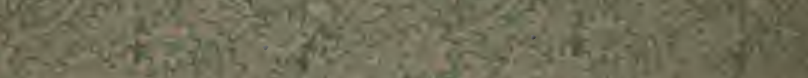

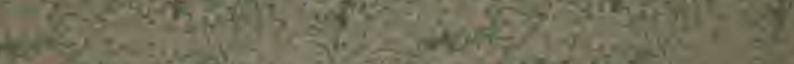

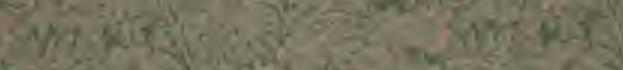

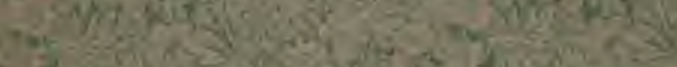

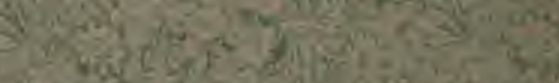

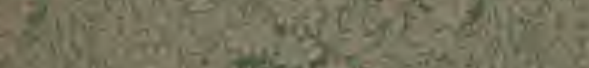

atying

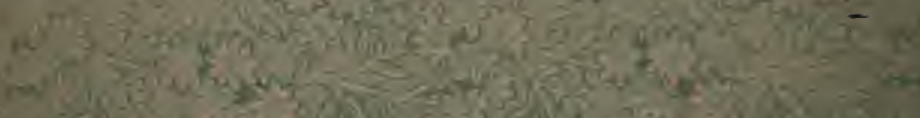

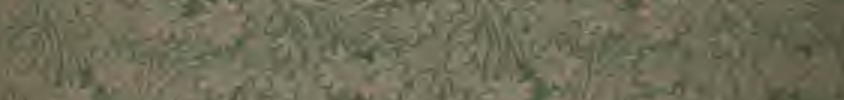

S.

+

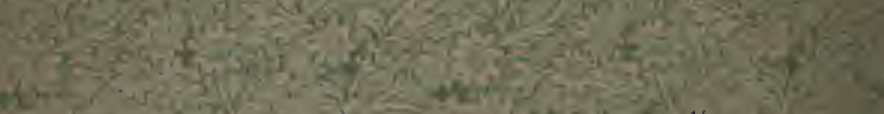

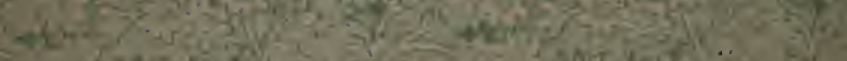

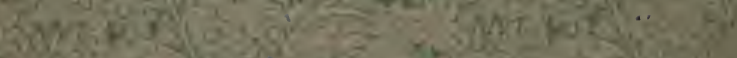

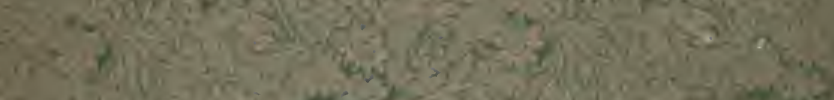

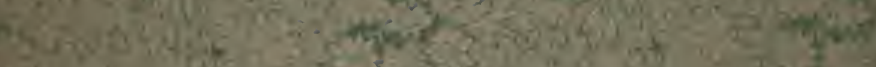

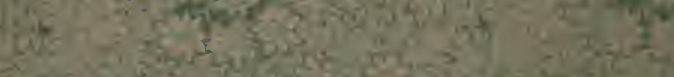

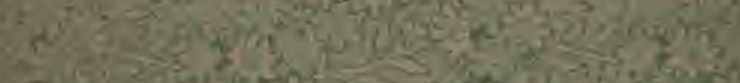

(2)

W.

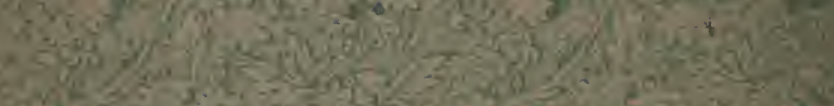

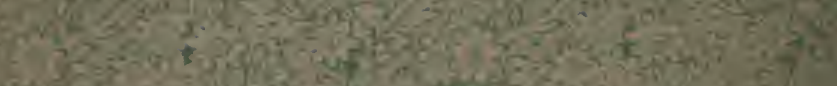

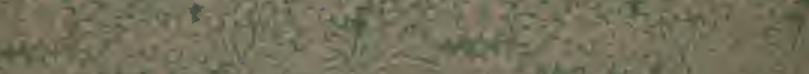

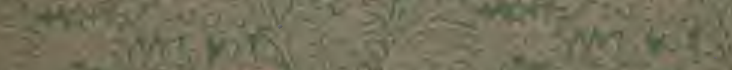

$\angle 3$.

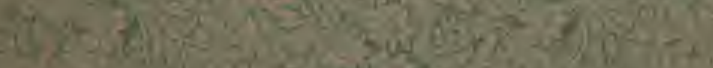

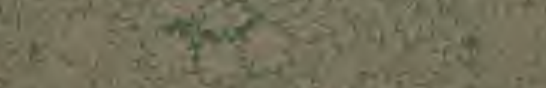

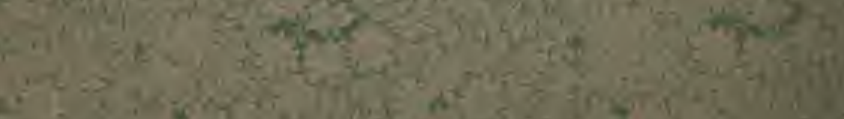




\section{University of Toronto Library

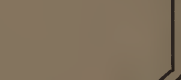

DO NOT

REMOVE

THE

CARD

FROM

THIS

POCKET

Acme Library Card Pocket Uıder Pat. "Ref. Index File" Made by LIBRARY BUREAU 


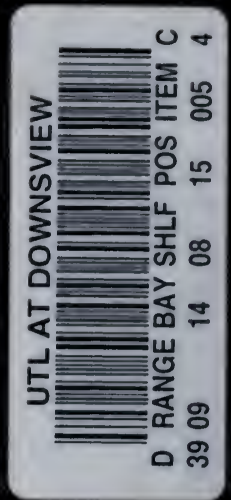

